\title{
Bendradarbiavimo su Lenkija įtaka Lietuvos energetiniam saugumui
}

\begin{abstract}
2006 m. Lenkijos koncernui „PKN Orlen“ issigijus kontrolinį naftos perdirbimo i̇monès "Mažeikių nafta“ akcijų paketą, Lietuvos ir Lenkijos politikai prakalbo apie naują etapą valstybių strateginèje partnerystëje. Entuziazmas dèl dvišalių santykių energetikos sektoriuje perspektyvu verčia kelti klausimą, kiek jis yra pagristas? Kodèl daugiau nei dešimt metų deklaratyvia laikyta strateginè partnerystė tapo pagrindine Lietuvos energetinio saugumo stiprinimo priemone? Straipsnyje siekiama įvertinti Lietuvos ir Lenkijos bendradarbiavimo atskiruose energetikos sektoriuose galimybes bei pavojus, taip pat numatyti tokio bendradarbiavimo pasekmes Lietuvos energetiniam saugumui. Tyrimui buvo pasitelktas geoenergetinių subjektų sąveikos modelis, nusakantis galimus subjektu interesus, tarpusavio ryšius ir poveikị energetinio saugumo būklei. Daroma išvada, kad energetinès strateginės partnerystės sukūrimas yra nę̨manomas dẻl skirtingų Lietuvos ir Lenkijos geoenergetinių funkcijų. Todèl siūloma nepervertinti dvišalio bendradarbiavimo perspektyvų ir nesieti su juo Lietuvos energetinio saugumo užtikrinimo.
\end{abstract}

\section{Ivadas}

2006 m. ir 2007 m. kaip jokie kiti metai buvo kupini Lietuvos energetikos sektoriui reikšmingų įvykiu. Po $2006 \mathrm{~m}$. sausio mèn. nutraukto gamtinių dujų tiekimo iš Rusijos per Ukrainą Europai, kilo didžiulis susirūpinimas energetiniu saugumu Europos Sajungoje, kuri parengė energetinio saugumo stiprinimo priemonių paketą. $2006 \mathrm{~m}$. pradžioje trijų Baltijos valstybių vyriausybių vadovai sutarė bendradarbiauti igyvendinant naujos atominès elektrinès statybos Lietuvoje projektą. $2006 \mathrm{~m}$. viduryje po avarijos naftotiekyje „Družba“ buvo nutrauktas naftos tiekimas Lietuvai. 2006 metais Lietuvos naftos perdirbimo gamyklos „Mažeikių nafta“ savininku tapo Lenkijos koncernas „PKN Orlen“. 2006 m. pabaigoje Lenkija deklaravo ketinimus prisijungti prie trijų Baltijos valstybių statant atominę elektrinę Lietuvoje. 2006-2007 metų žiemą dẻl Rusijos ir Baltarusijos nesutarimų dar kartą iškilo gamtinių dujų tiekimo nutraukimo grèsmè. 2007 m. pradžioje Lietuvos Respublikos Seimas patvirtino naują Nacionalinę energetikos strategiją, numatančią Lietuvos energetikos sektoriaus stiprinimo kryptis. $2007 \mathrm{~m}$. vid. buvo užbaigta Lietuvos ir Lenkijos elektros tiltų

\footnotetext{
* Kęstutis Budrys - Vilniaus universiteto Tarptautinių santykių ir politikos mokslų instituto doktorantas. Adresas: Vokiečiu 10, 01130 Vilnius, tel. 852514130.
} 
sujungimo galimybių studija, „Klaipėdos nafta“ tapo Odesa-Brodai-Plockas naftotieki statysiančios kompanijos akcininke. Dauguma šių ir kitų įvykiu yra susiję su Lietuvos santykiais su užsienio valstybėmis bei kompanijomis energetikos srityje.

Nuo 2006 m. vienas svarbesnių pokyčių Lietuvos užsienio ir energetikos politikoje yra intensyvesnis nei anksčiau bendradarbiavimas su Lenkija. Ši šalis jau daugiau nei dešimtmetį buvo laikoma Lietuvos „vartais" į Vakaru Europą ir galimybe Lietuvai užsitikrinti didesni energetinį saugumą - tokia nuostata vyravo visose Lietuvos nacionalinėse energetikos strategijose nuo 1994 metu. Tačiau visi bandymai padidinti lenkų suinteresuotumą plèsti jungtis su Lietuva buvo mažiau sèkmingi nei siekta. Esminis postūmis dvišaliam bendradarbiavimui energetikos srityje buvo 2006 m. „PKN Orlen“ įsigytas „Mažeikių nafta“ akciju paketas. Šis akcininkų pasikeitimas sužadino viltis, kad Lietuvos ir Lenkijos santykiai pereina i naują bendradarbiavimo ir tikros strateginès partnerystės etapą. Lietuvos Respublikos Prezidentas metiniame pranešime džiaugèsi bendradarbiavimu su kaimynais ir teigiamais poslinkiais 2006 m. - „Mažeikių nafta“ pardavimu ir susitarimu su Lenkija dèl dujotiekiu ir elektros tiekimo sistemų sujungimo ${ }^{1}$. Lietuvos Respublikos Vyriausybė 2006 m. veiklos ataskaitoje Lietuvos Respublikos Seimui teigè, kad „vis sparčiau plètojama Lietuvos ir Lenkijos strateginè partneryste்“, o tai ,irrodo konkretūs projektai““2. Tokios pačios nuomonès, kad „strateginè partnerystè su Lenkija igauna vis daugiau praktinių pavyzdžių", laikosi ir Lenkijos atstovai ${ }^{3} .2007$ $\mathrm{m}$. sausio $18 \mathrm{~d}$. Seimo nutarimu patvirtintoje Nacionalineje energetikos strategijoje (toliau - Nacionalinè energetikos strategija) numatyta valstybès misija „plètoti Lietuvos ir Baltijos šaliu, Lenkijos strateginę partnerystę bei glaudesnị tarpusavio bendradarbiavimą visuose energetikos sektoriuose (ypač elektros, dujų ir naftos)“4. 2007 m. pavasarị Lietuvos ministras pirmininkas Gediminas Kirkilas ir Lenkijos ministras pirmininkas Jaroslawas Kaczynskis pasirašè dvišali komunikatą, kuriame išreiškè paramą atominès elektrinės Lietuvoje statybai, elektros tilto tarp Lietuvos ir Lenkijos tiesimui, bendros ES energetikos politikos sukūrimui, galimybei sujungti Lietuvos ir Lenkijos dujotiekiu tinklus, siekiui spręsti naftos tiekimo į Lietuvą atnaujinimo klausimą ${ }^{5}$ Tokio

\footnotetext{
${ }^{1}$ Metinis Prezidento V. Adamkaus pranešimas (2007 m.), http:/ /www.president.lt/file/metinis2007. pdf, 20070826.

${ }^{2}$ Lietuvos Respublikos Vyriausybė, Nutarimas dèl Lietuvos Respublikos Vyriausybés 2006 metu veiklos ataskaitos pateikimo Lietuvos Respublikos Seimui, Nr. 307, 2007 m. kovo 21 d., http:/ / www.lrv. lt/14_vyr_dok/2006_veikl_atask.pdf, 20070904.

${ }^{3}$ Lietuvos Respublikos užsienio reikalu ministerija, Lietuvos ir Lenkijos strategine partnerysté igauna vis daugiau praktiniu pavyzdžiu, 2006 m. birželio 13 d., http:/ / www.urm.lt/index.php?1080257421, 20070806.

${ }^{4}$ Lietuvos Respublikos Seimas, Nutarimas dél Nacionalinès energetikos strategijos patvirtinimo, Nr. X-1046, 2007 m. sausio 18 d., http://www3.lrs.lt/pls/inter3/dokpaieska.showdoc 1?p id=291371, 20070901.

${ }^{5}$ Alfa.lt, Lietuva ir Lenkija spartina energetini bendradarbiavima, 2007 m. kovo 3 d., http:/ /alfa.lt/ straipsnis/127321, 20070805.
} 
plataus bendradarbiavimo užmojai kai kuriuos aukštus Lietuvos politikus net paskatino pradèti kalbèti apie „energetinès Žečpospolitos“ kūrimą - regiono energetinio saugumo garantą ${ }^{6}$.

Straipsnyje yra tikrinamos Lietuvos ir Lenkijos bendradarbiavimo energetikos sektoriuje galimybès bei tokio bendradarbiavimo pasekmès Lietuvos energetiniam saugumui. Tyrimui pasitelktas geoenergetinių subjektu tarpusavio santykių modelis, nusakantis pagrindinius geoenergetinių subjektu interesus ir energetinio saugumo kryptis, priklausomai nuo vyraujančios veiklos energetikos ūkiuose. Straipsnyje pateikiama Lietuvos ir Lenkijos santykiu gamtinių dujuc, elektros energetikos ir naftos sektoriuose analizė bei dvišaliu projektų vertinimai energetinio saugumo požiūriu. Straipsnyje nẻra vertinami Lietuvos santykiai su Lenkija ne energetikos srityje; vidaus energetikos politikos kryptys, kuriose nèra numatytas vaidmuo Lenkijai; Lietuvos santykiai energetikos sektoriuje su kitomis valstybėmis; Lenkijos energetikos politika su Lietuva nesusijusiose srityse. Išvadose teigiama, kad Lietuvos ir Lenkijos bendradarbiavimo energetikos srityje galimybès yra ribotos, todèl „energetinès Žečpospolitos" sukūrimas yra neįmanomas, o galbūt net ir netikslingas.

\section{Energetinio saugumo priklausomybè nuo geoenergetinès padèties}

\subsection{Geoenergetinių subjektų tarpusavio santykiai}

Energetinis saugumas neturi vieno konkretaus apibrèžimo. Energetinio saugumo samprata kinta priklausomai nuo subjekto (valstybės) geoenergetinès padèties. Valstybès geoenergetinę padèti nulemia jos energetikos sektoriaus vieta energetiniu išteklių ciklo grandinejje - gavyba/gamyba-transportavimas/perdirbimas-vartojimas. Vyraujanti veikla atskirame energetikos ūkyje (gamtinių duju, naftos, elektros energijos, anglies) gali būti: energetinių išteklių gavyba (gamtiniu duju, naftos) arba gamyba (elektros energija), energetiniu išteklių transportavimas (tranzitas), energetinių išteklių perdirbimas (gamtinių dujų suskystinimas, naftos perdirbimas) ir energetinių išteklių vartojimas (paskirstymo tinklai, atsargų talpyklos, mažmeninės prekybos tinklai). Atskiro energetikos ūkio vyraujančią veiklą nulemia, pirma, dominuojanti energetikos ūkyje infrastruktūra: gavybos, gamybos, transportavimo, perdirbimo ar vartojimo. Antras veiklos pobūdį nulemiantis veiksnys yra energetinių išteklių srautai, nes infrastruktūra gali būti ir nenaudojama (pavyzdžiui, naftos netiekiantis

\footnotetext{
${ }^{6}$ Žr. Tẻvynės Sajunga, Rusijos sulaikymo strategija. Rusijos ịtakos Lietuvoje mažinimo planas, $2007 \mathrm{~m}$. gegužès 9 d., http://www.visuomenei.lt/modules/document_publisher/documents/2/Rusijos \%20sulaikymo\%20strategijos\%20projektas\%2007\%2005\%2010.doc, 200709 03. Taip pat Kubilius A., "Mažeikiu nafta“ ir strategine partnerysté su Lenkija, 2006 m. gruodžio 18 d., http:/ / www3.lrs. lt/pls/inter/w5_show?p_r=4932\&p_d=62373\&p_k=1, 20070903.
} 
naftotiekis į Lietuvą): eksportas (gavyba), tranzitas (transportavimas), produktu eksportas (perdirbimas) ar importas (vartojimas). Dažniausiai viena valstybė atlieka skirtingas funkcijas skirtinguose energetikos ūkiuose. Dominuojanti funkcija visuose ūkiuose arba dominuojančio energetinio ištekliaus funkcija nulemia ir viso valstybės energetikos sektoriaus funkciją geoenergetinëje schemoje - jos geoenergetinę padètį. Valstybės funkcija geoenergetinèje schemoje yra tiesiogiai susijusi ir su jos geoekonomine padètimi.

Pagal vyraujančią veiklą energetikos ūkiuose valstybės gali būti skirstomos ị tiekèjas, transportuotojas ir/ar perdirbëjas bei vartotojas. Šis skirstymas yra sąlyginis, nes viena valstybe tuo pačiu metu gali atlikti ir visas funkcijas - tokiu atveju jai yra priskiriama dominuojanti veikla. Reikia atkreipti dėmesi, kad dominuojanti veikla gali kisti tiek dèl pasikeitusios infrastruktūros (pavyzdžiui, dèl pastatyto naftos eksporto terminalo), tiek dèl energetinių ištekliu srautu pokyčiu. Skirtingų geoenergetinių subjektų tarpusavio santykius lemia, pirma, subjektu geoenergetinis pobūdis ir, antra, tarpusavio ryšių intensyvumas. Tarpusavio ryšiu intensyvumas priklauso nuo energetinès infrastruktūros jungčių ir energetinių išteklių tarpusavio srautų.

Geoenergetinių subjektų santykius galima suskirstyti į šias grupes: santykiai tarp tiekejju, santykiai tarp transportuotoju ir perdirbèju, santykiai tarp vartotoju, santykiai tarp tiekèjų ir transportuotojų bei perdirbejju, santykiai tarp tiekèjų ir vartotoju, santykiai tarp vartotojų ir transportuotojų bei perdirbëjų. Geoenergetiškai reikšmingi tarpusavio ryšiai tarp skirtingu geoenergetinių subjektu yra tarpusavio priklausomybė. Tada, kai vienas geoenergetinis subjektas trumpuoju laikotarpiu negali išvengti kito geoenergetinio subjekto teikiamos paslaugos nesukeldamas grėsmės savo energetikos sektoriui. Pavyzdžiui, Lietuva negali išvengti/nutraukti gamtinių dujų importo iš Rusijos vamzdynais per Baltarusija, nes importo pajëgumai per Latviją yra nepakankami, todèl kiltu grėsmė jos energetiniam saugumui (nebūtụ patenkinta vidaus paklausa gamtinėms dujoms). Taip pat Lietuva negali nepirkti gamtinių dujų iš Rusijos, nes Lietuvą pasiekiančiais vamzdynais dujas tiekia tik "Gazprom“. Todèl Lietuva (vartotoja) yra priklausoma tiek nuo Baltarusijos (transportuotojos), tiek nuo Rusijos (tiekëjos). Geoenergetiškai reikšmingi tarpusavio ryšiai tarp tu pačiu geoenergetiniu subjektų (tarp vartotoju, tarp tiekejjų) yra tada, kai juos vienija tarpusavio priklausomybè nuo kito vieno (ar keliu) geoenergetinio subjekto (pavyzdžiui, dviejų ar daugiau tiekejju priklausomybė nuo vieno to paties vartotojo ar nuo tos pačios vartotoju grupès). 
1 lentelè. Geoenergetinių subjektų tarpusavio santykiai

\begin{tabular}{|c|c|c|c|c|}
\hline \multicolumn{2}{|c|}{$\begin{array}{l}\text { Objek- } \\
\text { tas } \\
\text { Subjek- } \\
\text { tas }\end{array}$} & Tiekèjas & $\begin{array}{c}\text { Transportuotojas ir/ar } \\
\text { perdirbejjas }\end{array}$ & Vartotojas \\
\hline \multirow[b]{3}{*}{ 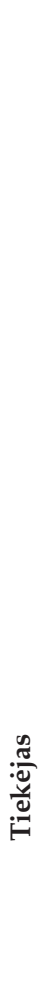 } & 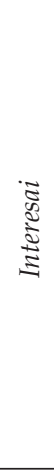 & $\begin{array}{l}\text { Išvengti konkuren- } \\
\text { cijos dèl vartotoju; } \\
\text { išvengti konkuren- } \\
\text { cijos dèl tranzito } \\
\text { valstybių }\end{array}$ & $\begin{array}{l}\text { Išvengti tranzito valstybiu } \\
\text { ir perdirbëjų; užsitikrinti } \\
\text { stabilų tiekimą; perimti } \\
\text { tranzito infrastruktūros } \\
\text { kontrolę ir nesudaryti salygu } \\
\text { transportuotojui daryti itaką } \\
\text { tiekèjui; užsitikrinti palan- } \\
\text { kiausias tiekimo sąlygas; jei } \\
\text { nepavyksta perimti tranzito } \\
\text { kontrolès - siekti diversifikuoti } \\
\text { tiekimo maršrutus arba iš viso } \\
\text { nutraukti ryšius su transpor- } \\
\text { tuotoju; perimti perdirbimo } \\
\text { kontrolę }\end{array}$ & $\begin{array}{c}\text { Monopolizuoti } \\
\text { tiekimą atskiriems } \\
\text { vartotojams; diversi- } \\
\text { fikuoti eksporto rinką; } \\
\text { didinti vartotojų } \\
\text { priklausomybę nuo } \\
\text { tiekëjo; plèsti i̇taką } \\
\text { energetiniu ištekliu } \\
\text { paskirstymo srityje }\end{array}$ \\
\hline & \multicolumn{4}{|c|}{ Lygiavertis subjektas } \\
\hline & 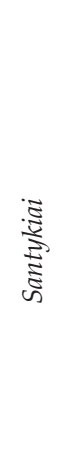 & $\begin{array}{l}\text { Konkurencija } \\
\text { Konkurencija dèl } \\
\text { vartotojų rinkos, } \\
\text { galimybe patekti } \\
\text { prie transportavimo } \\
\text { ir perdirbimo } \\
\text { infrastruktūros }\end{array}$ & $\begin{array}{c}\text { Bendradarbiavimas } \\
\text { Tiekèjas yra priklausomas } \\
\text { nuo tranzito infrastruktūros, } \\
\text { kuria energetiniai ištekliai yra } \\
\text { tiekiami vartotojams. Tiek } \\
\text { tiekëjas, tiek transportuoto- } \\
\text { jas yra suinteresuoti stabiliu } \\
\text { tiekimu ir tranzitu bei bend- } \\
\text { radarbiavimu su vartotojais. } \\
\text { Perdirbëjai yra priklausomi } \\
\text { nuo tiekimo, tiekèju santykiai } \\
\text { su perdirbëjais formuojasi taip } \\
\text { pat, kaip ir su vartotojais }\end{array}$ & $\begin{array}{l}\text { Bendradarbiavimas } \\
\text { Tiekëją ir vartotoją } \\
\text { sieja abipusė } \\
\text { priklausomybė. } \\
\text { Tiekëjas ir vartotojas } \\
\text { yra suinteresuoti } \\
\text { stabiliu tiekimu per } \\
\text { tranzito valstybes, } \\
\text { todèl plečia tranzito } \\
\text { maršrutu ivairovę. } \\
\text { Konkurencija dèl } \\
\text { galimybės patekti } \\
\text { prie perdirbimo } \\
\text { infrastruktūros }\end{array}$ \\
\hline \multicolumn{5}{|c|}{ Dominuojantis subjektas } \\
\hline & 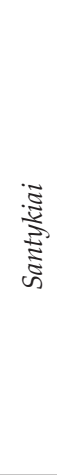 & $\begin{array}{l}\text { Kontrolès } \\
\text { perèmimas } \\
\text { Visu interesu } \\
\text { igyvendinimas }\end{array}$ & $\begin{array}{c}\text { Kontrolès } \\
\text { peremmimas } \\
\text { Visų interesu igyvendinimas }\end{array}$ & $\begin{array}{c}\text { Priklausomybès } \\
\text { didinimas } \\
\text { Tiekejjas riboja } \\
\text { vartotojo galimybę } \\
\text { diversifikuoti tiekimą, } \\
\text { siekia didinti vartotojo } \\
\text { priklausomybę ir mo- } \\
\text { nopolizuoti tiekimą. } \\
\text { Tai leidžia užsitikrinti } \\
\text { palankiausią tiekimo } \\
\text { kainą ir salygas, taip } \\
\text { pat - plèsti itaką } \\
\text { energetiniu išteklių } \\
\text { paskirstymo srityje }\end{array}$ \\
\hline
\end{tabular}




\begin{tabular}{|c|c|c|c|c|}
\hline \multirow{5}{*}{ 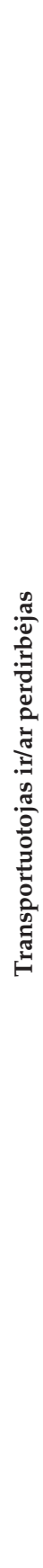 } & $\begin{array}{l}\tilde{\Xi} \\
\text { Jँ } \\
\text { I }\end{array}$ & $\begin{array}{c}\text { Didinti savo svarbą } \\
\text { tiekëju ir vartotoju } \\
\text { prekyboje energetin- } \\
\text { iais ištekliais; riboti } \\
\text { tiekëju galimybes } \\
\text { plësti perdirbimą; ri- } \\
\text { boti tiekejju galimybę } \\
\text { diversifikuoti } \\
\text { tiekimo maršrutą, } \\
\text { didinti tiekëju } \\
\text { priklausomybę nuo } \\
\text { tranzito ir perdirbi- } \\
\text { mo valstybëje }\end{array}$ & $\begin{array}{l}\text { Monopolizuoti tranzitą } \\
\text { ir perdirbimą; pašalinti } \\
\text { konkurentus, perimant jų } \\
\text { infrastruktūros kontrolę, } \\
\text { plečiant tranzito per } \\
\text { savo teritoriją galimybes; } \\
\text { užkirsti kelią glaudžiam } \\
\text { kitu transportuotoju ir/ar } \\
\text { perdirbëju bendradarbiavimui } \\
\text { su tiekėjais ir/ar vartotojais } \\
\text { energetinių ištekliu tranzito } \\
\text { ir/ar perdirbimo srityje, jei tai } \\
\text { gali sumažinti jo svarbą }\end{array}$ & $\begin{array}{c}\text { Didinti savo svarbą } \\
\text { tiekëjų ir vartotoju } \\
\text { prekyboje energetini- } \\
\text { ais ištekliais; } \\
\text { plèsti perdirbtos } \\
\text { produkcijos rinką; } \\
\text { riboti vartotoju } \\
\text { galimybę plèsti } \\
\text { perdirbimą; } \\
\text { riboti vartotoju } \\
\text { galimybę di- } \\
\text { versifikuoti } \\
\text { tiekimo maršruta, } \\
\text { didinti vartotojų } \\
\text { priklausomybę }\end{array}$ \\
\hline & \multicolumn{4}{|c|}{ Lygiavertis subjektas } \\
\hline & 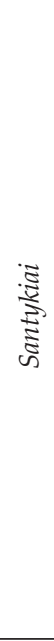 & $\begin{array}{c}\text { Bendradarbiavimas } \\
\text { Tiekejjas yra priklau- } \\
\text { somas nuo tran- } \\
\text { zito infrastruktūros, } \\
\text { kuria energetiniai } \\
\text { ištekliai yra tieki- } \\
\text { ami vartotojams. } \\
\text { Tiek tiekëjas, tiek } \\
\text { transportuotojas yra } \\
\text { suinteresuoti stabiliu } \\
\text { tiekimu ir tranzitu } \\
\text { bei bendradarbi- } \\
\text { avimu su vartotojais. } \\
\text { Perdirbëjai yra } \\
\text { priklausomi nuo } \\
\text { tiekimo, tiekèju san- } \\
\text { tykiai su perdirbëjais } \\
\text { formuojasi taip pat, } \\
\text { kaip ir su vartotojais }\end{array}$ & $\begin{array}{c}\text { Konkurencija } \\
\text { Transportuotojas ir/ar } \\
\text { perdirbejjas konkuruoja tar- } \\
\text { pusavyje dèl tu pačiu tiekejju } \\
\text { energetiniu ištekliu tranzito ir/ } \\
\text { arba perdirbimo vartotojams }\end{array}$ & $\begin{array}{c}\text { Bendradarbiavimas } \\
\text { Vartotojas yra prik- } \\
\text { lausomas nuo tranzito } \\
\text { infrastruktūros ir sta- } \\
\text { bilaus tiekimo. Trans- } \\
\text { portuotojas siekia } \\
\text { stabilių ir ilgalaikių } \\
\text { santykių }\end{array}$ \\
\hline & \multicolumn{4}{|c|}{ Dominuojantis subjektas } \\
\hline & 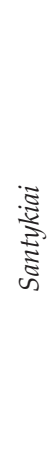 & $\begin{array}{l}\text { Priklausomybės } \\
\text { didinimas } \\
\text { Transportuotojas ir/ } \\
\text { ar perdirbëjas riboja } \\
\text { tiekejjo galimybes } \\
\text { diversifikuoti } \\
\text { tiekimo maršrutus ir } \\
\text { tiekimo rinkas, jei tai } \\
\text { sumažintu tranzito } \\
\text { ir perdirbimo svarbą }\end{array}$ & $\begin{array}{c}\text { Kontrolès perèmimas } \\
\text { Visų interesu igyvendinimas }\end{array}$ & $\begin{array}{l}\text { Priklausomybės } \\
\text { didinimas } \\
\text { Transportuotojas ir/ar } \\
\text { perdirbejjas riboja } \\
\text { vartotojo galimybes } \\
\text { diversifikuoti tiekimo } \\
\text { maršrutus, taip pat } \\
\text { diversifikuoti tiekëjus, } \\
\text { jei tai mažina jo } \\
\text { svarba. Energetiniu } \\
\text { ištekliu perdirbimo } \\
\text { srityje santykiai tokie } \\
\text { patys kaip tiekejo ir } \\
\text { vartotojo }\end{array}$ \\
\hline
\end{tabular}




\begin{tabular}{|c|c|c|c|c|}
\hline \multirow{5}{*}{$\frac{\stackrel{n}{*}}{\stackrel{0}{0}}$} & 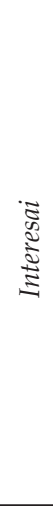 & $\begin{array}{l}\text { Stabilus tiekimas } \\
\text { priimtinomis kai- } \\
\text { nomis ir sąlygomis; } \\
\text { didinti tiekejjo } \\
\text { priklausomybę; } \\
\text { perimti gavy- } \\
\text { bos ir gamybos } \\
\text { infrastruktūrą }\end{array}$ & $\begin{array}{l}\text { Išvengti tranzito valstybių } \\
\text { ir perdirbejų; diversifikuoti } \\
\text { transportavimo maršrutą; } \\
\text { užsitikrinti stabilų tiekimą; } \\
\text { perimti tranzito infrastruktūros } \\
\text { kontrolę ir nesudaryti sąlygų } \\
\text { transportuotojui daryti įtaką } \\
\text { vartotojui; užsitikrinti pal- } \\
\text { ankiausias tiekimo sąlygas; } \\
\text { jei nepavyksta, tai perimti } \\
\text { tranzito kontrolę - siekti di- } \\
\text { versifikuoti tiekimo maršrutą } \\
\text { arba iš viso nutraukti ryšius } \\
\text { su transportuotoju; perimti } \\
\text { perdirbimo kontrolę }\end{array}$ & $\begin{array}{l}\text { Išvengti konkuren- } \\
\text { cijos dèl tiekëjų, } \\
\text { išvengti konkuren- } \\
\text { cijos dèl tranzito ir } \\
\text { perdirbimo - stabilus } \\
\text { tiekimas, priimtino- } \\
\text { mis sąlygomis }\end{array}$ \\
\hline & \multicolumn{4}{|c|}{ Lygiavertis subjektas } \\
\hline & 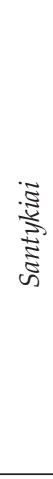 & $\begin{array}{l}\text { Bendradarbiavimas } \\
\text { Tiekëją ir vartotoją } \\
\text { sieja abipusè } \\
\text { priklausomybė. } \\
\text { Tiekëjas ir vartotojas } \\
\text { yra suinteresuoti } \\
\text { stabiliu tiekimu per } \\
\text { tranzito valstybes, } \\
\text { todèl plečia tranzito } \\
\text { maršrutų įvairovę. } \\
\text { Konkurencija dèl } \\
\text { galimybės patekti } \\
\text { prie perdirbimo } \\
\text { infrastruktūros } \\
\end{array}$ & $\begin{array}{l}\text { Bendradarbiavimas } \\
\text { Vartotojas yra priklausomas } \\
\text { nuo tranzito infrastruktūros ir } \\
\text { stabilaus tiekimo, todèl siekia } \\
\text { stabilių ir ilgalaikių santykių }\end{array}$ & $\begin{array}{l}\text { Konkurencija } \\
\text { Vartotojai konku- } \\
\text { ruoja dėl tiekëjų, } \\
\text { energetinių ištekliu } \\
\text { tiekimo keliu ir per- } \\
\text { dirbimo }\end{array}$ \\
\hline & \multicolumn{4}{|c|}{ Dominuojantis subjektas } \\
\hline & 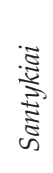 & $\begin{array}{c}\text { Kontrolès } \\
\text { perèmimas } \\
\text { Visų interesų } \\
\text { igyvendinimas } \\
\text { - konsolidacija }\end{array}$ & $\begin{array}{c}\text { Kontrolès perèmimas } \\
\text { Visų interesu igyvendinimas } \\
\text { - konsolidacija }\end{array}$ & $\begin{array}{l}\text { Kontrolès perèmimas } \\
\text { Visų interesų } \\
\text { igyvendinimas - kon- } \\
\text { solidacija }\end{array}$ \\
\hline
\end{tabular}

Kaip matyti 1 lentelëje, santykiai tarp geoenergetinių subjektu gali būti konkurencija, bendradarbiavimas, priklausomybės didinimas arba kontrolès perėmimas. Konkurencija dažniausiai sutinkama tarp lygiaverčių tų pačių geoenergetiniu subjektų (tarp tiekejuu, tarp transportuotoju, tarp vartotoju), pavyzdžiui: Irano ir Rusijos konkurencija dèl gamtinių dujų tiekimo į ES; Vengrijos ir Austrijos konkurencija dèl tapimo gamtinių dujų tiekëja i ES erdve; Indijos ir Kinijos konkurencija dẻl energetinių ištekliu tiekimo iš Artimujų Rytų. Bendradarbiavimas tikètinas taip pat tarp lygiaverčiu geoenergetiniu subjektu, tik skirtingų: tiekèju, transportuotojų ir/ar perdirbëjų bei vartotojų. Pavyzdžiui, bendradarbiavimas tarp Irano ir Kinijos naftos tiekimo srityje, tarp Turkijos ir Azerbaidžano tiekiant naftą į Vakaru Europą ir JAV. Kai bendradarbiauja visi trys skirtingi geoenergetiniai subjektai, galimas geoenergetinio regiono, 
apimančio visą energetinių išteklių ciklą, susiformavimas (kol kas vakarinė Eurazijos žemyno dalis yra vienintele geografine erdvė, kurioje toks regionas galètų susiformuoti). Tačiau jis turi apimti lygiaverčius partnerius, nes kitu atveju toks darinys bus trumpalaikis. Geoenergetiškai reikšmingi santykiai tarp skirtingų dydžių subjektų gali būti arba priklausomybès didinimas, arba kontrolès perėmimas. Priklausomybės didinimo pasekmė yra savarankiškumo mažèjimas ir pažeidžiamumo didejjimas, pavyzdžiui, Lietuvos priklausomybè nuo vienintelio gamtinių dujų tiekejjo ir dẻl to padidëjęs pažeidžiamumas Rusijos gamtinių dujų politikai. Kontrolès perèmimo pasekmė yra geoenergetinio subjektiškumo praradimas tam tikroje atskiro energetikos ūkio (arba viso energetikos sektoriaus) veikloje. Kontrolès perèmimas tai padariusiam subjektui (valstybei ar kompanijai) leidžia igyvendinti savo interesus, kurie yra determinuoti subjekto geoenergetinio pobūdžio. Kaip tik dèl šios priežasties beveik visos be išimčių valstybès daugiau ar mažiau riboja nekontroliuojamus nuosavybės santykių pokyčius energetikos sektoriuje. Energetikos sektoriaus įmonėms paprastai yra suteikiamas strateginiu įmonių statusas, nes nuo ju veiklos tiesiogiai priklauso ne tik energetinis, bet ir nacionalinis saugumas.

\subsection{Energetinio saugumo kriterijai}

Energetinis saugumas pirmiausia suponuoja energetinių išteklių tiekimo sąlygų neigiamų pokyčių rizikos minimizavimą. Energetinis saugumas santykiuose su kitais geoenergetiniai subjektais (arba kitaip - visada, kai geoenergetinis subjektas bendrauja energetikos sektoriuje su kitais subjektais) yra susijęs su savarankiškumu, diversifikacija, lankstumu ir stabilumu. Konkretesnis energetinio saugumo apibrèžimas priklauso nuo atskiro energetikos ūkio (arba viso energetikos sektoriaus) geoenergetinio pobūdžio. Tiekëjams energetinis saugumas yra diversifikuotų energetinių išteklių diversifikuotais keliais tiekimas į diversifikuotas ir stabilias rinkas priimtina kaina ir sąlygomis. Vartotojams energetinis saugumas yra diversifikuotų energetinių išteklių iš diversifikuotų ir stabilių šaltinių diversifikuotais keliais tiekimas priimtina kaina ir sąlygomis. Transportuotojams ir perdirbejjams energetinis saugumas yra diversifikuotu energetinių išteklių iš diversifikuotu ir stabilių šaltinių perdirbimas ir/ar tiekimas į diversifikuotas ir stabilias rinkas priimtina kaina ir sąlygomis. Be stabilumo ir energetinių išteklių diversifikacijos (priklausomybès nuo vieno energetikos ūkio), visi geoenergetiniai subjektai taip pat siekia išvengti energetikos sektoriaus išorinès monopolizacijos ir vertikalios integracijos.

Energetinis saugumas Lietuvoje taip pat yra siejamas daugiau su užsienio santykiais su kitomis valstybėmis nei su vidaus politika. Nacionalinėje energetikos strategijoje teigiama, kad energetinis saugumas yra grindžiamas šiomis nuostatomis ${ }^{7}$, pirma, energetinis saugumas yra sudètinė nacionalinio saugumo dalis. Antra, energetinio saugumo užtikrinimas reikalauja prognozuojamo,

${ }_{7}$ Žr. Nutarimas dèl Nacionalinès energetikos strategijos patvirtinimo. 
patikimo, ekonomiškai priimtino ir aplinką tausojančio energijos tiekimo. Trečia, energetinis saugumas aprépia visumą sąlygu, užtikrinančių tradicinių ir atsinaujinančių pirminių energijos šaltinių įvairovę, energijos tiekimo įvairovę ir patikimumą bei nepriklausomybę nuo monopolinio tiekèjo diktato, energijos pasiekiamumą vartotojui priimtinomis kainomis konkurencingoje energijos rinkoje. Ketvirta, Lietuva savo energetinị saugumą sieja su šalies energetikos sistemų integracija į ES energetikos sistemą ir su veiksminga ES ir nacionaline energetikos politika. Lietuvos energetinị saugumą galinčių užtikrinti strateginių uždaviniu igyvendinimui Nacionalinëje energetikos strategijoje didelis dèmesys yra skiriamas Lenkijai, be kurios ir Baltijos valstybių Lietuvai „būtų labai sunku arba beveik neįmanoma išspręsti“ energetinio saugumo problemųgamtinių duju tiekimo ilgalaikio patikimumo, būsimos naujos atominès elektrinès statybos ir elektros energijos sistemos integracijos ị ES sistemą?.

Siekiant numatyti tikètinas bendradarbiavimo su Lenkija pasekmes Lietuvos energetiniam saugumui, reikia ịvertinti, pirma, Lietuvos ir Lenkijos geoenergetinį pobūdi - vyraujančią veiklą atskiruose energetikos sektoriaus ūkiuose, antra, galimą santykių su Lenkija atskiruose energetikos sektoriaus ùkiuose krypti, trečia, santykiu atskirose kryptyse pobūdi, ketvirta, įvertinti tokių santykiu pasekmes Lietuvos energetiniam saugumui.

\section{Lietuvos ir Lenkijos santykiai gamtinių dujų sektoriuje}

\subsection{Lietuvos ir Lenkijos priklausomybè nuo importo iš Rusijos}

Nyderlandų energetikos tyrimų centro ir Tarptautinių santykių instituto "Clingendael" parengtoje studijoje apskaičiuoti energetinių ištekliu tiekimo saugumo indeksai9. Tiekimo saugumo indeksui apskaičiuoti buvo įvertintos visos galimos tiekimo nutraukimo ar sutrikimo priežastys visoje tiekimo grandinëje vidutiniu ir ilguoju laikotarpiu (nebuvo vertinti trumpojo laikotarpio sutrikimai ir valstybiu galimybės reaguoti į krizę). Tiekimo saugumo indeksas yra skirtas nustatyti ilgalaikę valstybės politiką energetiniam saugumui stiprinti,jis įvertina šalyje vartojamos pirminės energijos rūšis, šaltinius, nepriklausomybès laipsni, tiekimo keliu diversifikaciją, atsargas ir kitas stabiliam tiekimui būtinas sąlygas. Pagal šį rodiklį Lietuvos ir Lenkijos padètis skiriasi. 2005 m. Lietuvos tiekimo saugumo indeksas buvo šeštas (žemiausias ES - 45), Lenkijos buvo didesnis nei ES vidurkis (56) - 60. Studijoje, remiantis ES energijos vartojimo prognozėmis, buvo suskaičiuoti ir tiekimo saugumo indeksai 2020 metams.

\footnotetext{
${ }^{8}$ Ten pat.

${ }^{9}$ Plačiau žr. Scheepers M., Seebregts A., Jong J., Maters H., EU Standards for Energy Security of Supply. Updates on the Crisis Capability Index and the Supply/Demand Index Quantification for EU-27, http://www.ecn.nl/docs/library/report/2007/e07004.pdf, 20070816.
} 
Galima daryti išvadą, kad esant dabartinems tendencijoms, Lietuvos padètis mažai keisis, jos indeksas bus 43, o Lenkijos išliks didesnis nei ES vidurkis (2020 m. - 53) - 55. Ši situacija rodo skirtingą Lietuvos ir Lenkijos energetinị pažeidžiamumą, taip pat objektyviai prastesnę Lietuvos padètį Europos prekyboje energetiniais ištekliais.

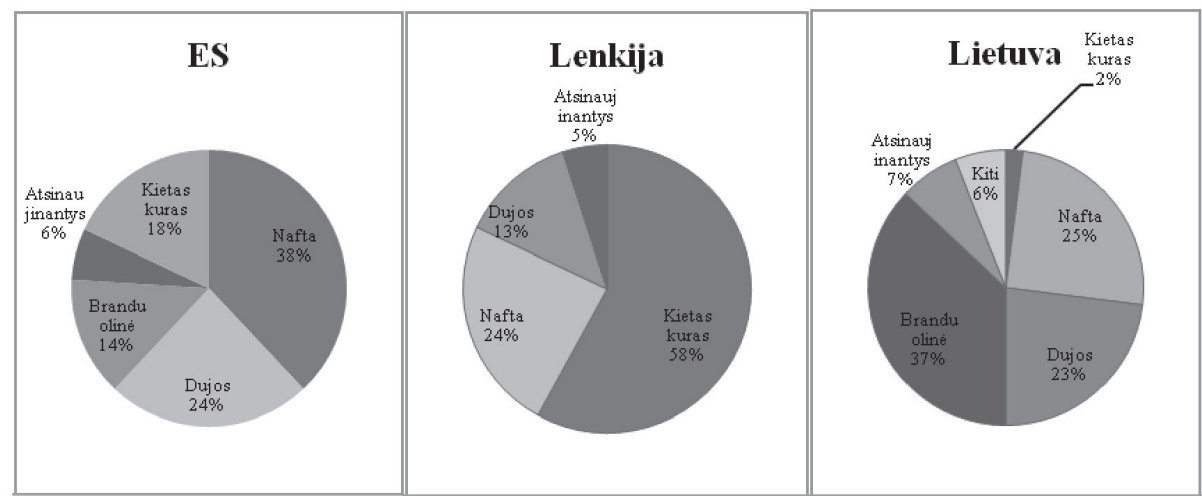

1 pav. ES, Lietuvos ir Lenkijos suvartojamų pirminès energijos šaltinių palyginimas, $2004 \mathrm{~m} .^{10}$

ES 2006 m. iš Rusijos importavo 39 proc. visų importuojamu gamtinių dujų. Rusijos dalis importo struktūroje nuolat auga, nors $2006 \mathrm{~m}$. ir buvo pastebètas $1 \%$ kritimas (2005 m. Rusijos gamtinès dujos sudarè $40 \%$ viso importo) ${ }^{11}$. Tačiau šis kritimas turètų būti siejamas su bendru gamtinių duju vartojimo smukimu 2006 m. (5,4 \%), kurị sukèlè tikriausiai šilta žiema. Rusijos gamtinių dujų eksporte ES dalis sudaro $54 \%{ }^{12}$, todèl ne visai teisinga yra teigti, kad tik ES priklauso nuo Rusijos - ES ir Rusiją objektyviai sieja abipuse priklausomybè.

\footnotetext{
${ }^{10}$ Commission of the European Communities, Commission Staff Working Document, EU Energy Policy Data, SEC(2007)12, 10 October, 2007, http:/ / ec.europa.eu/energy/energy_policy/doc/02_eu_energy_policy_data_en.pdf, 20070810.

${ }^{11}$ Jimenez A., "Statistical Aspects of the Natural Gas Economy in 2006", Eurostat Data in Focus, 14/2007, http:/ / epp.eurostat.ec.europa.eu/cache/ITY_OFFPUB/KS-QA-07-014/EN/KS-QA-07014-EN.PDF, 20070810.

${ }^{12}$ Rusija 2006 m. išgavo 556 mlrd. $\mathrm{m}^{3}$ duju, eksportavo $262,5 \mathrm{mlrd} . \mathrm{m}^{3}$, iš ju į $\mathrm{ES}-142 \mathrm{mlrd}$. kubinių metrų. Žr. OAO Gazprom, Annual Report 2006, http://www.gazprom.com/documents/Report_Eng.pdf, 20070715.
} 
2 lentelè. Gamtinių dujų importo priklausomybè Lietuvoje ir Lenkijoje, mln. $\mathrm{t}^{13}$

\begin{tabular}{|c|c|c|c|}
\hline & & Lietuva & Lenkija \\
\hline \multirow{3}{*}{ Gavyba } & 2005 & 0 & 4,3 \\
\hline & 2006 & 0 & 4,3 \\
\hline & $2005 / 2006, \%$ & 0 & $-0,7$ \\
\hline \multirow{3}{*}{ Importas } & 2005 & 2,8 & 9,5 \\
\hline & 2006 & 2,8 & 9,9 \\
\hline & $2005 / 2006, \%$ & $-1,6$ & 4,8 \\
\hline \multirow{3}{*}{$\begin{array}{l}\text { Resursai } \\
\text { (gavyba + importas) }\end{array}$} & 2005 & 2,8 & 13,8 \\
\hline & 2006 & 2,8 & 14,2 \\
\hline & $2005 / 2006, \%$ & $-1,6$ & 3,1 \\
\hline \multirow{2}{*}{ Atsargų pokyčiai } & 2005 & 0 & $-0,2$ \\
\hline & 2006 & 0 & $-0,5$ \\
\hline \multirow{3}{*}{ Eksportas } & 2005 & 0 & 0 \\
\hline & 2006 & 0 & 0 \\
\hline & $2005 / 2006, \%$ & 0 & 0,2 \\
\hline \multirow{3}{*}{$\begin{array}{l}\text { Vartojimas } \\
\text { (resursai+atsargos-eksportas) }\end{array}$} & 2005 & 2,8 & 13,5 \\
\hline & 2006 & 2,8 & 13,7 \\
\hline & $2005 / 2006, \%$ & $-1,6$ & 1,1 \\
\hline \multirow{2}{*}{$\begin{array}{l}\text { Energetinè priklausomybè } \\
\text { (importas-eksportas)/vartojimas }\end{array}$} & 2005, proc. & 100 & 69,7 \\
\hline & 2006, proc. & 100 & 72,2 \\
\hline
\end{tabular}

Visai kitokia nei ES yra Lietuvos ir Lenkijos padètis gamtinių dujų sektoriuje. Lenkija 2006 m. importavo 72,2 \% visų suvartojamu gamtinių dujų, Lietuva - 100 procentų (žr. 2 lentelę). Tačiau importuojamų išteklių dalies vartojime nustatymas mažai ką tepasako, būtina atsižvelgti ir į kitus faktorius: pirma, importo diversifikavimą, antra, importuojamų išteklių svarbą pirminiu valstybëje suvartojamų išteklių balanse ir, trečia, išteklius importuojančios šalies svarbą eksportuotojui (tiekëjo priklausomybę nuo vartotojo). ES priklausomybẻ nuo gamtinių dujų importo siekia $61 \%{ }^{14}$, tačiau importas yra diversifikuotas (žr. 2 paveikslą) - Rusijos dalis sudaro 39 procentus. Gamtinės dujos ES pirminiu energijos šaltinių balanse sudaro ketvirtadalį - 24 procentus (̌̌r. 1 paveikslą). Dar daugiau - Rusijai ES rinka yra strateginè, nes, kaip minèta, 54 \% iš viso gamtinių dujų eksporto keliauja į ES.

\footnotetext{
${ }^{13}$ Jiménez.

${ }^{14}$ Ten pat.
} 


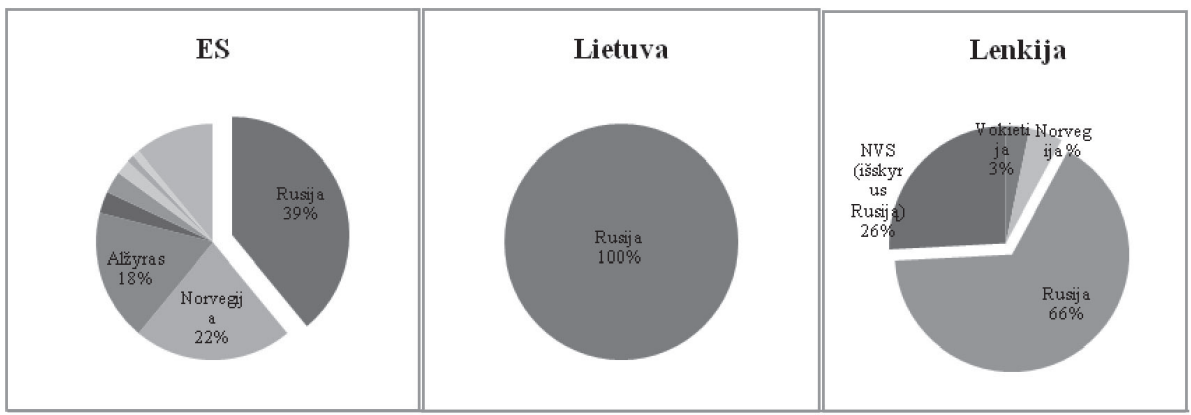

2 pav. ES, Lietuvos ir Lenkijos gamtinių dujų importas, 2006 m. $^{15}$

Lenkijos gamtinių dujų importas yra mažiau diversifikuotas nei ES Rusijos dalis sudaro 66 procentus. Tačiau gamtinės dujos šalyje suvartojamu energijos šaltinių balanse siekia vos 13 procentų. Dèl šių priežasčių Lenkijos energetikos ūkis yra mažiau pažeidžiamas per gamtinių dujų sektorių nei visos ES, nors Lenkija ir daugiau priklauso nuo gamtinių dujų importo iš $\mathrm{Ru}$ sijos. Tačiau Lenkijos situacija ateityje keisis, nes, pirma, dèl aplinkos saugos reikalavimų turès mažèti kieto kuro (pirmiausia anglies) naudojimas šalyje, todèl didès gamtinių dujų dalis pirminès energijos šaltinių balanse (2004 $\mathrm{m}$. Lenkijoje buvo prognozuojama ${ }^{16}$, kad $2010 \mathrm{~m}$. gamtiniu duju vartojimas padidès iki 18,5-19,3 mlrd. $\mathrm{m}^{3}$ ). Antra, dides importas, nes gamtinių duju gavyba šalyje neauga, atsargos mažëja, o vartojimas didëja (žr. 3 paveikslą). Galima prognozuoti, kad Lenkijos priklausomybè nuo gamtinių dujų importo apskritai ir nuo Rusijos konkrečiai ateityje tik augs.

\footnotetext{
${ }^{15}$ Ten pat. Taip pat The BP Statistical Review of World Energy 2007, http://www.bp.com/liveassets/bp_internet/globalbp/globalbp_uk_english/reports_and_publications/statistical_energy_review_2007/STAGING/local_assets/downloads/spreadsheets/statistical_review_full_report_workbook_2007.xls, 20070612.

${ }^{16}$ „Wintershall сделала предложение Польше“, РБК daily, 2007 m. gegužès 31 d., http://www.rbcdaily. ru/2007/05/31/tek/278103, 20070801.
} 


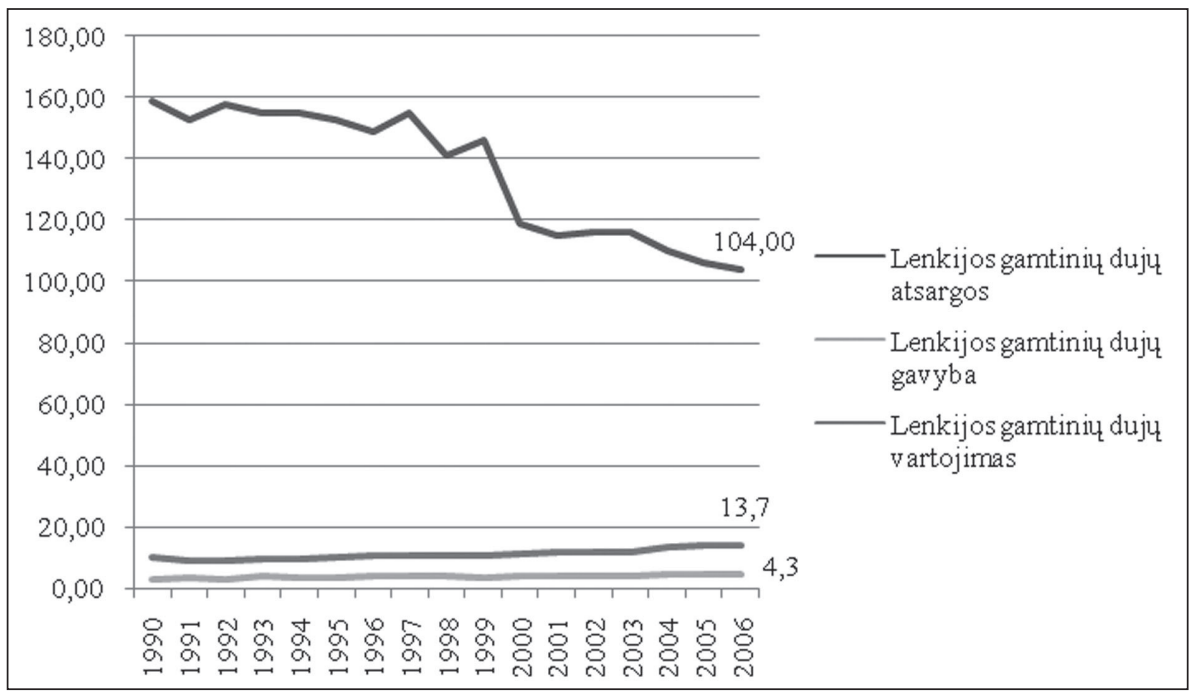

3 pav. Lenkijos gamtinių dujų gavyba, vartojimas ir atsargos ${ }^{17}$

Lietuvos situacija yra daug blogesnè nei ES ar Lenkijos. Gamtinės dujos 2006 $\mathrm{m}$. sudarė $28,5 \%$. pirminès energijos išteklių ${ }^{18} .100 \%$ ju importuojama iš Rusijos - importas yra visiškai nediversifikuotas. Be to, Lietuvos rinka yra nereikšminga Rusijos eksportui - Lietuva importuoja tik 1,4\% visų eksportuojamų Rusijos dujų. Ši kieki "Gazprom" be papildomu pastangu galètų nukreipti i dar pelningesnę rinką. Net ir drauge su Lenkija, dviejų šalių importas tesudaro 4,9\% viso eksporto (2006 m. Rusijos gamtinių dujų eksportas siekè 201,13 mlrd. $\left.\mathrm{m}^{3}\right)^{19}$.

\subsection{Lietuvos ir Lenkijos reikšmè Rusijos gamtinių dujų eksportui ị Vakarų Europą}

Lietuva nėra svarbi gamtinių dujų tranzito valstybė. Per Lietuvą tranzitu tiekiamos dujos tik į Kaliningrado sritic - $2006 \mathrm{~m}$. transportuota 1,2 mlrd. $\mathrm{m}^{3}$ gamtinių dujų. Nors šis dydis išaugo 66,9 \%, jei lygintume su 2005 m. (0,721 mlrd. $\left.\mathrm{m}^{3}\right)^{20}$, Lietuva negali būti laikoma tranzito erdve geoenergetine prasme (kaip transportavimo funkcijas atliekanti valstybė) jau vien todèl, kad tranzito dydis nesiekia vartojimo apimčių. Šiuo metu tranzito apimtys sudaro $42,9 \%$ vidaus

\footnotetext{
${ }^{17}$ The BP Statistical Review of World Energy 2007.

${ }^{18}$ Statistikos departamentas prie Lietuvos Respublikos Vyriausybès, Energetikos statistika 2006 m., http:/ / www.stat.gov.lt/lt/news/view/?id=1923, 20070620.

19 "Russian Oil Exports Down 1\%, Gas Exports 3\% in 2006-Ministry“ , RIA Novosti, 2007 m. vasario 1 d., http: / /en.rian.ru/russia/20070201/60026020.html, 20070830.

${ }^{20} \mathrm{AB}$ „Lietuvos dujos“, 2006 m. konsoliduotas metinis pranešimas, http:/ / www.vpk.lt/uploads/metinis_pranesimas_2006.pdf, 20070801.
} 
vartojimo. Kita vertus, jei būtų plečiami dujotiekio per Lietuvą į Kaliningrado sritį pajègumai, Lietuva taptų vis svarbesne gamtinių dujų tranzito erdve. Ši perspektyva tiesiogiai priklauso nuo mažiausiai dviejų faktoriu, pirma, gamtinių dujų paklausos Kaliningrado srityje ir, antra, nuo "Gazprom" ir Kremliaus sprendimo dèl Kaliningrado srities aprūpinimo gamtinėmis dujomis keliu. Kaliningrado srities paklausa $2012 \mathrm{~m}$. sieks ${ }^{21}$ beveik $2 \mathrm{mlrd} . \mathrm{m}^{3}$. Šis papildomas kiekis galès būti tiekiamas arba padidinus perdavimo pajègumus iš Lietuvos ị Kaliningrado sritį (iš Baltarusijos į Lietuvą jie yra pakankami), arba nutiesus dujotiekio "Nordstream" Baltijos jūros dugnu atšaką ị Kaliningrado sritị. Kaliningrado srities tolimesnio dujofikavimo klausimas yra politinis, todèl vargiai galima tikètis ekonominiais argumentais paremto jo sprendimo. Kaip tik dèl šios priežasties nèra atmetama iki $1 \mathrm{mlrd}$. JAV doleriu kainuosiančios „Nordstream" atšakos tiesimo į Kaliningrado sritį idejja ${ }^{22}$. Galima prognozuoti, kad blogejant Lietuvos ir Rusijos santykiams, politinè parama gamtinių dujų tiekimo didinimui aplenkiant Lietuvą stiprès, o Lietuvos perspektyvos tapti gamtinių dujų tranzito valstybe - mažès.

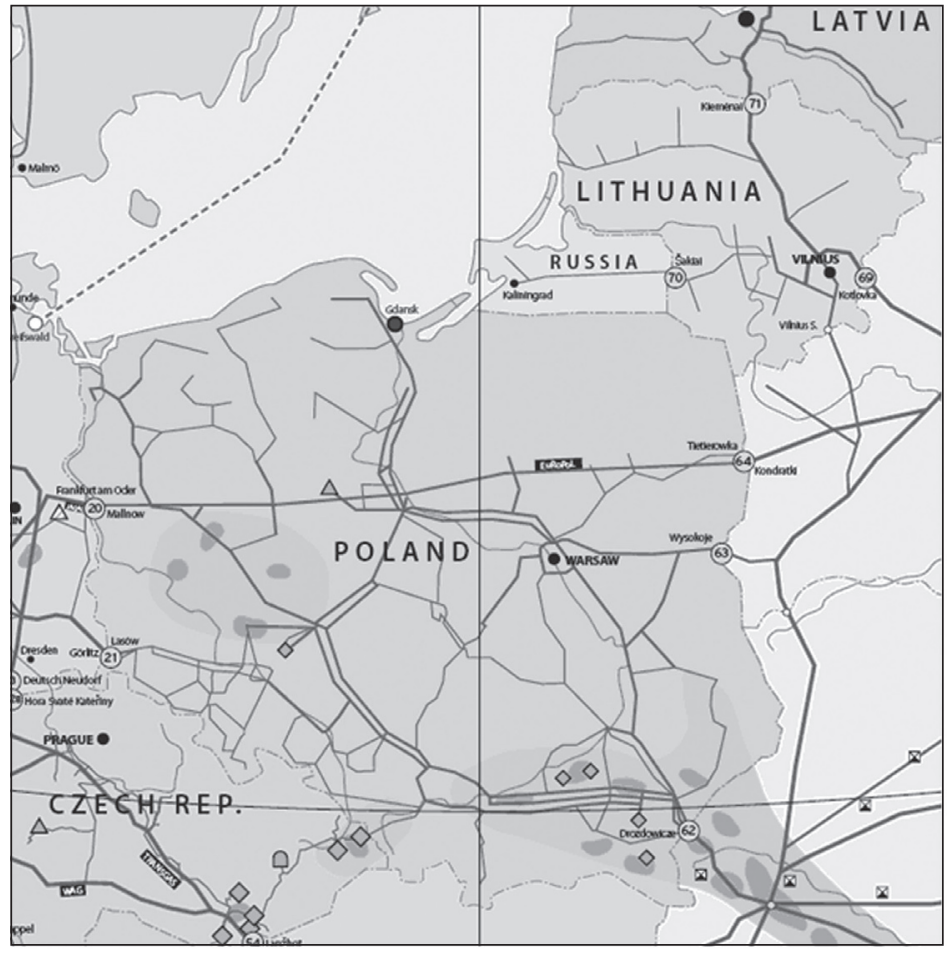

1 žemèlapis. Lietuvos ir Lenkijos dujotiekių tinklas ${ }^{23}$

\footnotetext{
${ }^{21}$ Рагузина Г., Калининград стал заложником амбиций энергетического и газового гигантов, http:// www.bellona.ru/articles_ru/chubais_tec, 20070623.

22 Ten pat.

${ }^{23}$ Gas Transmission Europe, Operational Procedures at major cross-border interconnection points, http://www.gie.eu.com/download/gridmap/GTE OP 150.pdf, 20070716.
} 
Lenkijos svarba Rusijos gamtinių dujų eksportui į Vakarų Europą Lenkijos kaip gamtinių dujų tranzito valstybès - šiuo metu yra didelè. Per Lenkiją į Vokietiją "Jamalas-Europa" dujotiekiu (projektinis pajėgumas 33 mlrd. $\mathrm{m}^{3}$ ) kasmet tiekiama apie 25-26 mlrd. $\mathrm{m}^{3}$ dujų ${ }^{24}$. Sis kiekis, palyginus su Lenkijoje suvartojamų gamtinių dujų kiekiu (2006 m. - 13,7 mlrd. m³), leidžia Lenkijai vadintis gamtinių dujų tranzito valstybe. Tai reiškia, kad Lenkija gali daryti įtaką Rusijos ir Vakarų Europos prekybai gamtinėmis dujomis, taip pat, kad Rusija neturi svertų paveikti Lenkijos gamtinių dujų ūkio, nepažeisdama partnerių Vakarų Europoje (pirmiausia Vokietijos) interesų. Kaip gamtinių duju tranzito valstybė gali išnaudoti savo padètį konflikte su tiekèju, puikiai parodė Baltarusijos ir Rusijos konfliktai dèl gamtinių dujų kainų 2004 ir 2006 m. - vienintelè Minsko garantija, kad Maskva ilgam neuždarys dujų tiekimo buvo tranzitas per Baltarusiją į Vakarų Europą.

\subsection{Tikètini Lietuvos ir Lenkijos nacionalinių gamtinių dujų sektorių geoenergetiniai pokyčiai}

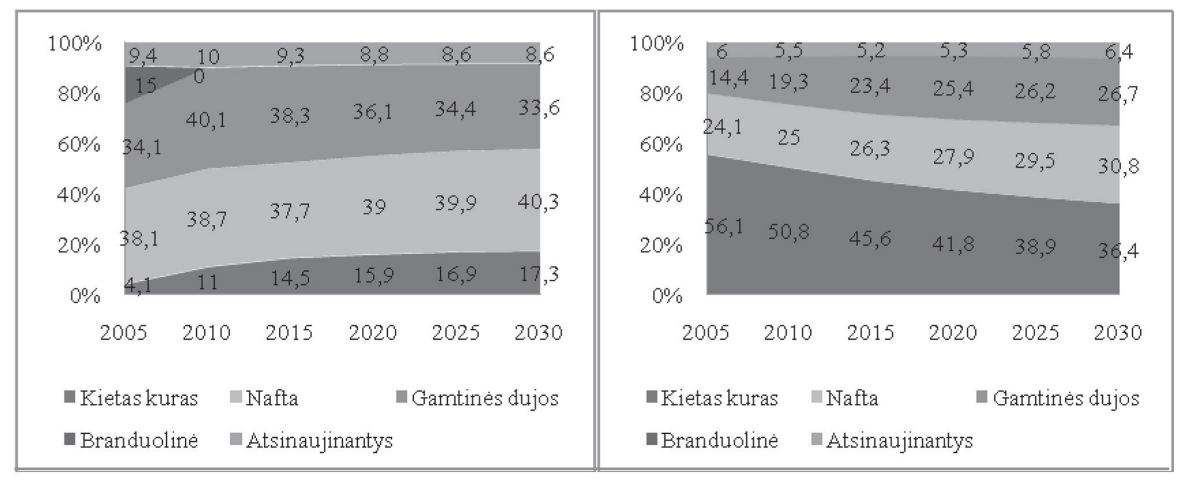

\section{4 pav. Lietuvos ir Lenkijos pirminių energijos šaltinių balanso prognozè $\dot{e}^{25}$}

Darant prielaidą, kad nebus igyvendinti Lietuvos ir Lenkijos padèti keičiantys energetikos projektai - statoma atominė elektrinė Lietuvoje, tiesiami nauji dujotiekiai, statomi suskystintu gamtinių dujų terminalai - turètų kisti abiejų šaliu pirminės energijos šaltinių balansai (žr. 4 paveikslą). Lietuvos balanse didžiausias pokytis būtų branduolinès energijos vartojimo išnykimas ir su tuo susijęs gamtinių dujų vartojimo santykinis didejjimas trumpuoju-vidu-

\footnotetext{
${ }^{24}$ Успенский А., „Поляки требуют от „Газпрома“ отдать долг. EuRoPol GAZ подсчитала разницу в тарифах“, РБК daily, 2007 m. sausio 17 d., http://pda.daily.rbc. $\mathrm{ru} / 2007 / 01 / 17 /$ tek/263467.shtml, 20070511.

${ }^{25}$ European Commission, Directorate-General for Energy and Transport, European Energy and Transport Trends to 2030, $2003 \mathrm{~m}$. sausio 30 d., http:/ / ec.europa.eu/dgs/energy_transport/figures/trends_2030/1_pref_en.pdf, 20070412.
} 
tiniu laikotarpiu. Tačiau gamtinių dujų dalis balanse turètų grižžti ị dabartinę padètị ilguoju laikotarpiu. Lietuvos gamtinių dujų vartojimo augimas yra reikšmingas tik nacionaliniu mastu - per 20 metų vartojimas išaugs apie 1 mlrd. $\mathrm{m}^{3}$ per metus. Tai yra jokios įtakos regiono gamtinių duju rinkai nedarantis kiekis. Lietuva išliks 100 \% priklausoma nuo Rusijos. Todèl galima daryti išvadą, kad Lietuvos gamtinių dujų sektoriaus padètis energetinio saugumo požiūriu (diversifikacijos, santykinès dalies pirminių energijos šaltinių balanse, reikšmès eksportuotojui) iš esmès nesikeis. Žinoma, gamtinių dujų vartojimo elektros energijos generavime augimas didins viso Lietuvos energetikos ūkio pažeidžiamumą.

Lenkijos gamtinių dujų ūkio prognozès energetinio saugumo požiūriu yra blogesnès nei Lietuvos. Gamtinių duju dalis pirminių energijos šaltiniu balanse turètų padidèti nuo 14,4\% 2005 m. iki 26,7 \% 2030 m. (žr. 5 paveikslą). Per ši laikotarpi vartojimas išaugs daugiau nei 2,5 karto, trečdaliu sumažės gavyba (žr. 3 paveikslą). Importas turètų išaugti daugiau nei 3 kartus, o Lenkijos priklausomybė nuo importo pasiekti 92,6 \% 2030 m. (2006 m. ji buvo 72,2 procento).

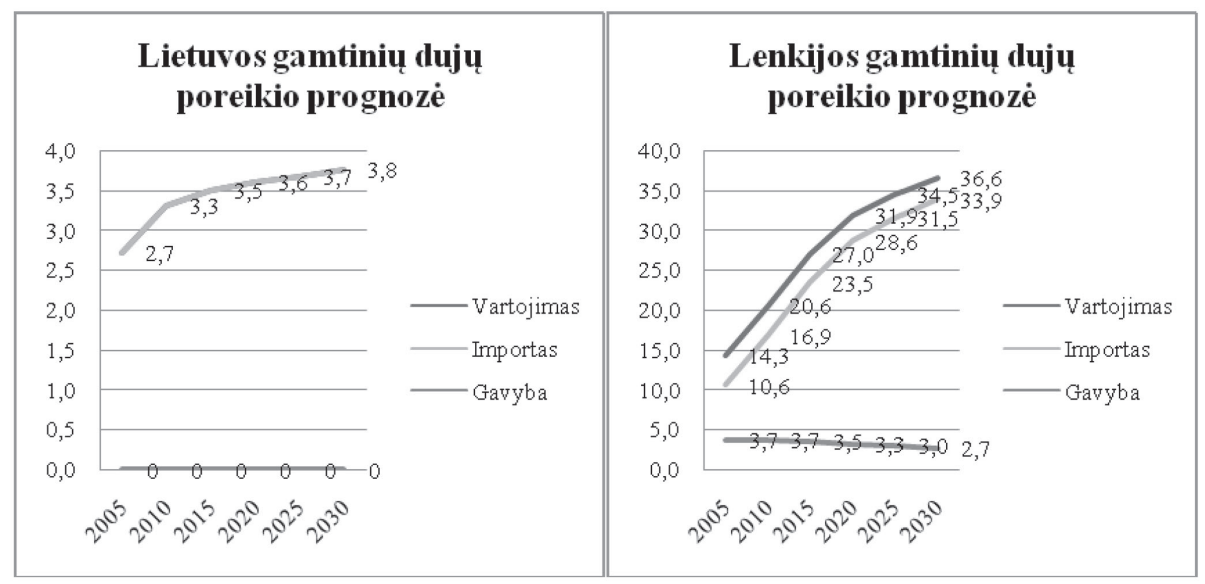

\section{5 pav. Lietuvos ir Lenkijos gamtinių dujų vartojimo, importo ir gavybos prognozé丶 26}

Nesikeičiant gamtinių dujų importo į Lenkiją struktūrai, Lenkija papildomas dujas turès importuoti iš Rusijos. Remiantis „Rusijos energetikos strategija iki 2020 m. ${ }^{\prime 27}$, Rusijos gamtinių dujų eksportas turètų didèti apie 30 \% 2000-2010 m., 4,5 \% 2010-2015 m., 1,4 \% 2015-2020 m. ir 2020 m. pasiekti $281 \mathrm{mlrd} . \mathrm{m}^{3}$. Netgi vadovaujantis nepagrịsta prielaida (per daug optimistine),

\footnotetext{
${ }^{26}$ Ten pat.

${ }^{27}$ Правительство Российской Федерации, Энергетическая стратегия России на период до 2020 года, No. 1234-p, 200308 28, http://www.minprom.gov.ru/docs/strateg/1/print, 20061125.
} 
kad Rusijos gamtinių dujų eksportas ir toliau didès taip sparčiai, kaip didejjo 2015-2020 m., $2030 \mathrm{~m}$. jis turètų siekti $290 \mathrm{mlrd} . \mathrm{m}^{3}$. Darant prielaidą, kad papildomas dujas Lenkija importuos iš Rusijos, Lenkijos dalis 2020 m. Rusijos gamtinių duju eksporte sudarytu 9,1\% (importuos 28,6 mlrd. $\mathrm{m}^{3}$, iš jų apie 25 mlrd. iš Rusijos), 2030 m. - 10,7 procento. Atrodytu, kad dešimtadalis iš viso Rusijos gamtiniu duju importo galètų suteikti Lenkijai daugiau svertu derantis su Rusija. Kita vertus, gamtiniu duju vartojimo augimas prognozuojamas ne tik Lenkijoje ar Lietuvoje, bet ir visoje Europoje. Todèl labai tikètina, kad vyks intensyvi konkurencija dèl Rusijos gamtinių duju. Mažai tikètina, kad Lenkija po keliolikos ar net po keliasdešimt metu atrodys patrauklesnė pagal jos ekonomiką ir politiką Rusijai nei, pavyzdžiui, Vokietija ar Prancūzija. Dèl šių priežasčiu Lenkijos energetinio saugumo būklè ateityje tik blogès, jei nebus imamasi radikaliu ir ją gerinančiu priemonių.

Šias negatyvias tendencijas, kaip buvo minèta, galètų neutralizuoti Rusijos gamtinių dujų tranzito augimas. Vienintelis tikras gamtinių dujų tranzito augimo per Lietuvą scenarijus - dujotiekio iš Lietuvos ị Kaliningrado sriti pajègumų didinimas. Tai yra numatyta ir 20070118 Lietuvos Nacionalinëje energetikos strategijoje: „plèsti ir modernizuoti šalies duju perdavimo tinklus ir užtikrinti, kad gamtinių dujų tranzitas per Lietuvą būtų didinamas ir jam būtu taikomos sąlygos, atitinkančios ES teisès aktus bei praktiką “228. Prognozuojama, kad, jei Kaliningradas laikysis nuosaikios srities ekonominès plètros scenarijaus, 2010 m. reikės 4,8 TWh elektros energijos, o 2020 m. - 5,8 TWh (2005 m. Kaliningrado sritis suvartojo 3,6 TWh elektros energijos) ${ }^{29}$. Atsižvelgiant i tai, kad, uždarius Ignalinos atominės elektrinès antraji bloką, po $2010 \mathrm{~m}$. Lietuva negalės eksportuoti elektros energijos į Kaliningrado sriti, šiam papildomam kiekiui elektros gaminti sritis statosi papildomą gamtinėmis dujomis kūrenamą bloką Kaliningrado šiluminëje elektrinèje. Pirmąji 450 MW bloką buvo leista eksploatuoti $2005 \mathrm{~m}$., jis per metus suvartoja apie $0,6 \mathrm{mlrd} . \mathrm{m}^{3}$ duju (dirbant visu pajègumu $\left.-0,75 \mathrm{mlrd} . \mathrm{m}^{3}\right)^{30}$. Pastačius naujajį bloką, srities poreikis gamtinėms dujoms išaugs mažiausiai 0,75 mlrd. $\mathrm{m}^{3}$, kurios turès būti tiekiamos arba per Lietuvą, arba nutiesus dujotiekio Baltijos jūros dugnu "Nordstream“ atšaką i Kaliningrado sritị. Labiausiai tikètina, kad ekonominè logika nusvers politinius išskaičiavimus ir "Gazprom“ dujomis aprūpins per Lietuvą. Tai padès išlaikyti Lietuvos reikšmę ne Rusijos gamtinių dujų eksportui, bet ir aprūpins Rusijos vidaus regionus. Energetinio saugumo požiūriu, vertinant tiekëjo galimybę apriboti tiekimą, tai yra ne mažiau svarbu nei būti eksportuojamų ištekliu tranzito valstybe.

\footnotetext{
${ }^{28}$ Nutarimas del Nacionalinés energetikos strategijos patvirtinimo.

${ }_{29}^{29}$ Баланс электроэнергии Калининградской энергосистемь на период до 2020 года, http://impera. ru/region/economics/electricity, 20070604.

30 „Калининградская ТЭЦ-2 полностью обеспечивает потребителей области собственной электроэнергией“, Пресс-релиз Калининградская ТЭЦ-2, 2007 m. rugpjūčio 28 d., http://www.ktec2. net/index.php?type=555\&subcat=146, 20070901.
} 
Lenkijos, kaip Rusijos gamtinių dujų tranzito valstybės, perspektyvos yra miglotos. Lenkijoje augsiantis gamtinių dujų vartojimas mažins tranzito apimtis. Galima prognozuoti, kad šiuo metu dujotiekiu Jamalas-Europa tiekiamas Vokietijai dujas (25-26 mlrd. $\mathrm{m}^{3}$ per metus) Lenkijai teks suvartoti pačiai (importas iki $2020 \mathrm{~m}$. turès padidèti $18 \mathrm{mlrd}$. $\mathrm{m}^{3}$ ), o tai mažins jos, kaip tranzito valstybės, reikšmę. Jei nebus Lenkijoje plečiama tranzitiniu dujotiekių infrastruktūra, šalis taps tik vartotoja - paskutiniu tašku gamtiniu duju tiekimo grandinèje. Energetinio saugumo požiūriu, jei bus plečiamas gamtinių dujų tiekimas per Lietuvą į Kaliningrado sritî, Lietuva turès geresnę padèti nei Lenkija, nors ir importuos $100 \%$ duju iš Rusijos. Šią abieju šaliu situaciją galètu pakeisti regione planuojami ir igyvendinami gamtinių duju infrastruktūros projektai.

\subsection{Gamtinių dujų infrastruktūros projektụ ịtaka šalių energetiniam saugumui}

\subsection{1. „Nord Stream“ dujotiekis}

Turbūt daugiausia aistru pastaruoju metu Europoje sukẻle šiuo metu Rusijos sausumos dalyje jau statomas dujotiekis „Nord Stream“ (anksčiau vadinosi „Śiaurès Europos“ dujotiekiu). Naujasis dujotiekis ${ }^{31}$ turètų sujungti Vakarų Sibiro telkinį ,Južno Russkoje“ su Vokietija ir nusidriekti Baltijos jūros dugnu (nuo Vyborgo Suomijos ịlankoje iki Greifsvaldo Vokietijoje). Neatmetama galimybė vèliau ji pratęsti ir iki Olandijos bei Jungtinės Karalystės krantu. Planuota, kad dujotiekio atšakos taip pat galetu pasiekti Švediją bei Suomija. Dujotiekis drieksis per penkiu šalių išskirtinę ekonominę zoną: Rusijos, Suomijos, Švedijos, Danijos ir Vokietijos ${ }^{32}$. Projektinis dujotiekio pajėgumas sieks $55 \mathrm{mlrd} . \mathrm{m}^{3}$ per metus, dujotiekio statybos kaina - daugiau nei 5 mlrd. euru. Projektas yra įtrauktas į Transeuropos energetikos tinklo (TEN-E) Europos intereso projektų sąrašą, kuriame nurodyti svarbiausi šaliu jungčių projektai, reikalaujantys kuo spartesnio igyvendinimo ir nuo kurių priklauso ES energetikos politikos uždavinių igyvendinimas ${ }^{33}$. „Nord Stream“ dujotiekis

31 Projektas igyvendinamas remiantis $2005 \mathrm{~m}$. sudaryta "Gazprom“, „BASF AG“ ir „E.ON AG“ sutartimi, kuria buvo ịkurta dujotiekio kompanija "North European Gas Company“", kuri vèliau pervadinta ì "Nord Stream AG". "Gazprom" priklauso $51 \%$ įmonès akcijų, likusius $49 \%$ po lygiai dalijasi „BASF AG“ ir „E.ON AG“. Prie dujotiekio statybos prisijungė ar išreiške norą tai padaryti taip pat ir kitos Europos kompanijos: Prancūzijos "Gaz de France“, Jungtinés Karalystès BP, Norvegijos "Norsk Hydro“, Nyderlandu „Gasunie“ ir kitos. Dujotiekio pagrindiniai statybos darbai turètu prasidèti $2008 \mathrm{~m}$. antroje pusëje.

${ }^{32}$ Plačiau apie projektą žr. Nord Stream, Project Information Document: Offshore Pipeline Through the Baltic Sea, November 2006, http:/ / www.nord-stream.com/uploads/media/PID_ENGLISH_01.pdf, 20070722.

${ }^{33}$ Commission of the European Communities, Communication from The Commission to The Council and The European Parliament. Priority Interconnection Plan, COM(2006) 846 final, 2007 m. sausio $10 \mathrm{~d}$., http://dete.parliament.bg/pub/ECD/COM_2006_846_EN_ACTE_f.pdf, 20070802. 
priskiriamas NG1 jungčiai - dujotiekiu jungtis tarp Didžiosios Britanijos, Šiaurinès kontinentinės Europos ir Rusijos. Tai pačiai NG1 jungčiai priskirtini ir kiti, konkuruojantys projektai - ,Jamalas-Europa“ antroji linija ir „Amber".

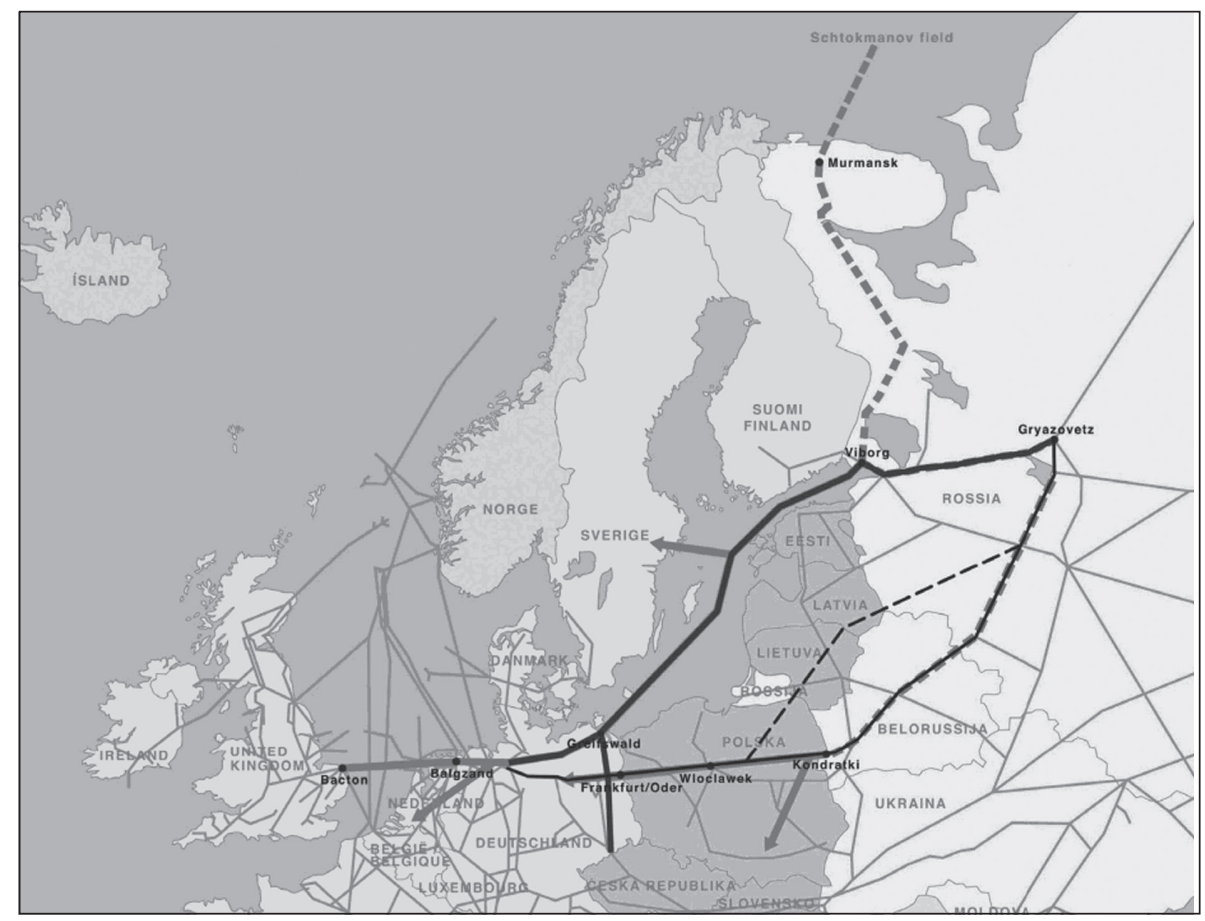

2 žemèlapis. Statomi ir planuojami dujotiekiai ${ }^{34}$

„Nord Stream" dujotiekiu „Gazprom“ siekia tiekti dujas į Vakarų Europa, o dèl politinių ir ekonominiu priežasčių aplenkti Vidurio Europos valstybes. Dujotiekiais aplenkti šias valstybes galima tik tiesiant vamzdynus jūromis. Deklaruojama, kad "Nord Stream “ projektas Rusijos dujų monopolininkei „Gazprom" leis igyvendinti du pagrindinius tikslus: pirma, išplèsti dujų transportavimo eksporto ị Europą pajègumus ir, antra, diversifikuoti dujų eksportą bei sumažinti tranzitinių šalių (Ukrainos, Baltarusijos bei Lenkijos) įtaką rusiškų dujų eksportui. Rusijos gamtines dujas perkančios Vakarų Europos šalys taip pat yra suinteresuotos, kad dujotiekių maršrutai kirstų kuo mažiau tranzitinių šalių. Tiesioginis (be tarpininkų) susisaistymas su tiekëju užtikrina ilgalaiki stabilų tiekima, nes, pirma, tiekimas nepriklauso nuo tiekejjo ir tranzito šalių santykių (Ukrainos ir Baltarusijos patirtis), antra, tiekëjas turi mažiau galimybių diversifikuoti eksportą ir perorientuoti tiekimą - tampa priklausomas nuo pirkëjo, trečia, sumažejja rizika, kad, išaugus gamtiniu dujų vartojimui tranzito šalyje, sumažès tiekiamų dujų kiekis.

\footnotetext{
${ }^{34}$ Морской газопровод через Балтийское море (проект), http://www.mnr.gov.ru/part/ ?act=more\&id=1291\&pid=781, 20070715.
} 
Labiausiai nesuinteresuotos dujotiekiu turètų būti Rusijos gamtinių dujų tranzito šalys: Ukraina, Baltarusija ir Lenkija. Šias šalis apeinančių dujotiekių plètra mažina jų įtaką Rusijos gamtinių dujų eksportui ir didina jų energetinị pažeidžiamumą. Tačiau viešai „Nord Stream“ prieštarauja tik Lenkija ir Lietuva. Lenkijos prieštaravimas yra puikiai suprantamas, nes ji bando įtikinti Vakaru Europą ir Rusiją, kad tiesti dujotieki sausuma yra pigiau. Lenkijos ekspertai visai pagristai baiminasi, kad, nutiesus dujotieki, bus atsisakyta vykdyti 1993 m. Rusijos ir Lenkijos vyriausybiu pasirašytą susitarimą dèl dujotiekio „Jamalas-Europa“ antrosios linijos statybos. Dẻl to Lenkija ne tik patirs finansinių nuostolių, bet ir sumažès jos geoenergetinè įtaka gamtiniu dujų eksportui į Vakarų Europą.

Lietuvai „Nord Stream“ dujotiekis grèsmę energetiniam saugumui kels tik tuo atveju (ekologiniam, kariniam saugumui pasekmès šiame straipsnyje nèra vertinamos), jei bus nuspręsta tiesti atšaką i Kaliningrado srití, ir eksklavas nebebūtų priklausomas nuo gamtinių dujų tranzito per Lietuvą. Tokia tikimybè kol kas yra minimali, tačiau, smarkiai pablogèjus Rusijos ir Lietuvos santykiams, Maskva gali ryžtis „apsaugoti“ savo sritį nuo „priešiškai nusiteikusių, savanaudžių" kaimynių.

Todèl Lietuva dujotiekio statybos atžvilgiu galètų būti lankstesnè nei Lenkija, nes abiejų šalių interesai šiuo klausimu ne visai sutampa. Lenkija siekia pastatyti "Jamalas-Europa" dujotiekio antrają liniją ir padidinti tranzitą. Per Lietuvą tranzitas nè vienu atveju nepadidètu, todèl Lietuvai, energetinio saugumo požiūriu, nèra didelio skirtumo, ar dujotiekis bus tiesiamas Baltijos jūros dugnu, ar per Lenkiją. Žinoma, su sąlyga, kad, kaip minèta, Kaliningrado sritis nebus sujungta su "Nord Stream".

\subsection{2. „Jamalas II“ ir „Amber“}

„Jamalas-Europa“ antrosios linijos projektas (dar vadinamas „Jamalas-Europa II" arba "Jamalas II") net ES Pirmenybinio sujungimo plane yra vadinamas „Nord Stream“ konkurentu, kuri „,remia Lenkija ir Baltijos valstybès ${ }^{\prime \prime 35}$. Lietuvos parama šiam projektui galètų būti pateisinama tik vienu atveju - jei jame būtų numatyta atšaką i Lietuvą, taip Lietuvai sudarant galimybes diversifikuoti gamtinių dujų tiekimo į šalį maršrutus (tiekẻjas išliktų tas pats) ir sumažinti gamtinių dujų tiekimo nutraukimo galimybę. Tačiau tokių nuostatų projekte nèra.

„Jamalas II" projektas numato dujotiekio iš Rusijos į Vokietiją statybą per Baltarusiją ir Lenkiją greta pirmosios "Jamalas-Europa“ linijos. Dujotiekio ilgis turètų būti $700 \mathrm{~km}$, pajègumas -43 mlrd. $\mathrm{m}^{3}$, kaina $-1,5 \mathrm{mlrd}$. eurų ${ }^{36}$. Tokio kiekio tranzitas per Lenkiją (turint omenyje, kad pirmaja linija gabenamas dujas Lenkija suvartotų pati) užtikrintų jai svarbios tranzito valstybės statusą ir paja-

\footnotetext{
${ }^{35}$ Priority Interconnection Plan.

${ }^{36}$ Ten pat.
} 
mas iš tranzito mokesčio, Lenkija taptų Vakarų Europos energetinio saugumo veiksniu, o tai jai suteiktų ir politinės galios. Lenkijos dujų kompanija PGNiG pateikè paraišką Europos Komisijai atlikti projekto galimybių studiją. Europos Komisija sutiko ją finansuoti su sąlyga, kad bus įtrauktos suinteresuotų šaliu narių kompanijos. Tačiau Lenkijai pavyko užsitikrinti tik Baltijos valstybių vyriausybiu paramą. Nè viena dar kompanija neprisijungė prie PGNiG, kuri buvo priversta 20060127 atsiimti paraišką. Tokią projekto baigti (nors jis vis dar ir yra Pirmenybinio sujungimo plane) lèmé pirmiausia "Gazprom“ ir Vokietijos „E.ON AG" nesuinteresuotumas projektu. Šios kompanijos sutarè igyvendinti alternatyvu - „Nord Stream“ - projektą, numatanti panašaus kiekio gamtiniu dujų transportavimą į tą pačią rinką.

Galima prognozuoti, kad „Jamalas II" dujotiekis greičiausiai bus tiesiamas tik po to, kai, pirma, pradès visa galia veikti "Nord Stream", antra, sparčiau nei prognozuojama augs Vakarų Europos gamtinių duju paklausa, trečia, Rusijoje sparčiau nei prognozuota didès gamtinių duju gavyba, ketvirta, Vakarų Europa bus linkusi didinti gamtinių dujų importą iš Rusijos, penkta, Baltarusija ir Lenkija nebus Maskvoje laikomos valstybėmis, kurias geriau aplenkti plètojant vamzdynų infrastruktūrą. Mažai tikètina, kad kada nors visos šios sąlygos būtų igyvendintos, tačiau net jei taip atsitiktų, prie "Jamalas II" projekto nebus grižta anksčiau nei 2015-2020 metais.

Nors ES alternatyva „Nord Stream“ yra laikomas Lietuvos energetinio saugumo nesustiprinsiantis "Jamalas II", Lietuvoje kaip alternatyva "Nord Stream“ pateikiamas dujotiekis „Amber" ${ }^{\prime \prime 37}$. Pavyzdžiui, Nacionalinèje energetikos strategijoje įtvirtinta nuostata, kad vienas pagrindinių veiksniu, darančiu įtaką stabiliai energetikos veiklai Lietuvoje, yra „naujo dujotiekio i̇ Europą tiesimas ne per Baltijos valstybiu teritorijas, bet Baltijos jūros dugnu“38. Tačiau "Amber" net nèra ES Pirmenybinio sujungimo plane, jis pažymètas tik kaip „bendro intereso" projektas ${ }^{39}$. Lenkijoje dujotiekis turètų driektis lygiagrečiai „Jamalas-Europa“" pirmajai linijai, todèl ji galima būtų laikyti tam tikra alternatyva "Jamlas II".

„Amber" galètų padidinti Lietuvos energetinį saugumą. Pirma, Lietuva galètų integruotis į ES dujotiekių tinklą ir būti laikoma vieningos ES gamtiniu dujų rinkos dalimi. Antra, būtų diversifikuoti gamtinių dujų tiekimo iš Rusijos keliai, o tai sumažintų tiekimo nutrūkimo (ar nutraukimo) galimybes. Trečia, "Amber" padarytų Rusijos gamtinių dujų eksportą priklausomą nuo Lietuvos stabilus tiekimas į Vakarų Europą priklausytų nuo stabilaus tranzito per

\footnotetext{
${ }^{37}$ „Amber" dujotiekiu iš pradžių buvo vadintas kitas projektas, parengtas Danijos gamtinių duju kompanijos DONG ir turejęs Daniją per Lenkiją sujungti su Baltijos valstybėmis. Tačiau jo dar $2003 \mathrm{~m}$. buvo atsisakyta.

${ }^{38}$ Nutarimas del Nacionalinés energetikos strategijos patvirtinimo.

${ }^{39}$ The European Parliament and The Council Of The European Union, Decision of The European Parliament and of The Council. Laying Down Guidelines for Trans-European Energy Networks and Repealing Decision 96/391/EC and Decision No 1229/2003/EC, No 1364/2006/EC, 2006 m. rugsëjo 6 d., http://eur-lex.europa.eu/LexUriServ/site/en/oj/2006/1_262/1_26220060922en00010023. pdf, 20070115.
} 
Lietuvą. Tai sumažintų Rusijos galimybes manipuliuoti gamtinių dujų tiekimo i Lietuvą kiekiu ir kaina. Ketvirta, padidètų Lietuvos svarba aprūpinant energetiniais ištekliais Kaliningrado sritị. Penkta, Lietuva gautų pajamų už gamtinių dujų tranzitą.

Projekto perspektyva atrodo patraukliai, tačiau „Amber" igyvendinimo galimybės yra minimalios. Jis negali konkuruoti net su "Jamalas II“ projektu: antrosios "Jamalas" linijos statybai nereikètu papildomai išpirkti žemès, gauti įvairiausių leidimu, taip pat užtektu padidinti jau esančių kompresorinių pajègumus ir panašiai. Jei dèl kažkokių priežasčių būtų atsisakyta "Nord Stream" projekto, mažai tikètina, kad "Gazprom“ ir Vokietijos kompanijos nuspręstu derètis su Baltijos valstybėmis, tapti nuo jų priklausomomis, mokèti joms tranzito mokesčius vien dèl to, kad išvengtų tranzito per Baltarusiją. „Amber" projektas galètų būti įgyvendintas tik tada, kai, pirma, pilnu pajègumu pradès veikti „Nord Stream“ ir "Jamalas II", antra, šiais dujotiekiais tiekiamos dujos vis dar nepatenkins Vakarų Europos šaliu paklausos, trečia, Rusija vis dar turès galimybiu didinti gamtinių dujų gavybą Vakarų Sibire, ketvirta, Rusija vis dar norès didinti eksportą i Vakaru Europą ir nesieks jo diversifikuoti, penkta, Vakaru Europos šalys norės didinti importą iš Rusijos tuo pačiu koridoriumi, šešta, Rusija norės paversti Baltijos valstybes gamtinių dujų tranzito erdve ir tapti nuo ju priklausoma. Darant prielaidą, kad neįmanomų dalykų nebūna, visos šios sąlygos galètų būti igyvendintos už bent kiek patikimo prognozuojamumo ribos - ne anksčiau nei 2030 metais. Todèl ši alternatyva negali būti laikoma pagrịstu projektu, su ja neturètų būti siejamos Lietuvos energetinio saugumo stiprinimo viltys.

\subsubsection{Lietuvą ir Lenkiją jungiantis dujotiekis}

Lietuvos Nacionalinëje energetikos strategijoje teigiama, kad viena iš Lietuvos energetikos sektoriaus silpnybiu yra tai, kad „Lietuvos elektros ir duju tinklai neturi jokių tiesioginiu ryšių su Vakarų Europos energetikos sistemo$\mathrm{mis}^{\prime \prime 40}$. Kaip galimybès yra nurodytos, pirma, suskystintu gamtinių duju (toliau - SGD) terminalo Baltijos regione statyba (nebūtinai Baltijos valstybèse). SGD terminalo statyba yra įvardijama ir tarp Lietuvos interesų ir uždaviniu Baltijos regione: "gamtinių dujų tiekimo sistemos plètra bei jungtys tarp sistemų su ES dujų tinklais, numatant kartu su Latvijos, Lenkijos ir Estijos ekspertais išnagrinėti regioninio suskystintu gamtinių dujų importo terminalo statybos tikslingumą “41. Antra, Lietuvos ir Lenkijos dujotiekiu tinklų sujungimas, leisiantis tiekti gamtines dujas iš alternatyvių šaltinių (Kaspijos jūros regiono ir Norvegijos).

Nacionalinëje energetikos strategijoje minimas dujotiekis galètų sujungti Lietuvos dujotiekių sistemą su, pirma, Rusijos gamtines dujas transportuojančiais tranzitiniais vamzdynais per Lenkiją, antra, Lenkijoje planuojamu statyti suskystintų gamtinių dujų importo terminalu, trečia, alternatyvių Rusijai šalių -

\footnotetext{
${ }^{40}$ Nutarimas dél Nacionalinés energetikos strategijos patvirtinimo.

${ }^{41}$ Ten pat.
} 
Norvegijos, Kaspijos šaliu - išteklius transportuojančiais dujotiekiais Lenkijoje. Visi šie projektai -SGD terminalas, tranzitiniai dujotiekiai iš Rusijos, dujotiekiai iš Norvegijos ar Kaspijos - yra arba sunkiai igyvendinami, arba per maži, kad prie ju galètu jungtis Lietuva. Vienintelis projektas, numatantis Rusijos gamtines dujas transportuojančio dujotiekio tiesima, yra "Jamalas II“. Tačiau jis, pirma, greitai nebus igyvendinamas, jeigu iš viso bus, antra, nèra numatytas Lietuvos prisijungimas prie šio dujotiekio. Lietuva galètų prisijungti prie suskystintu gamtinių dujų terminalo Lenkijoje, jei, pirma, šis terminalas būtų Lenkijoje pastatytas, antra, importo pajègumų užtektų ir Lietuvai, trečia, terminalas būtų netoli Lietuvos sienos, nes kitu atveju dujotiekio tiesimo nauda nepateisins išlaidų. Taip pat ir dèl Lietuvos prisijungimo prie dujotiekių iš Norvegijos ir/ar Kaspijos: pirma, jie turi Lenkiją pasiekti, antra, jais transportuojamų duju turi užtekti ir Lietuvai, trečia, jie neturi būti per daug nutolę nuo Lietuvos-Lenkijos sienos. Todèl Lietuvos ir Lenkijos „energetinę strateginę partnerystę“ galintis įtvirtinti dujotiekis galètų būti tiesiamas tik tada, kai bus nuspręsta prie kokio iš šių projektų Lietuva prisijungs. Beje, šie projektai turi būti iš tikrujų iggyvendinami.

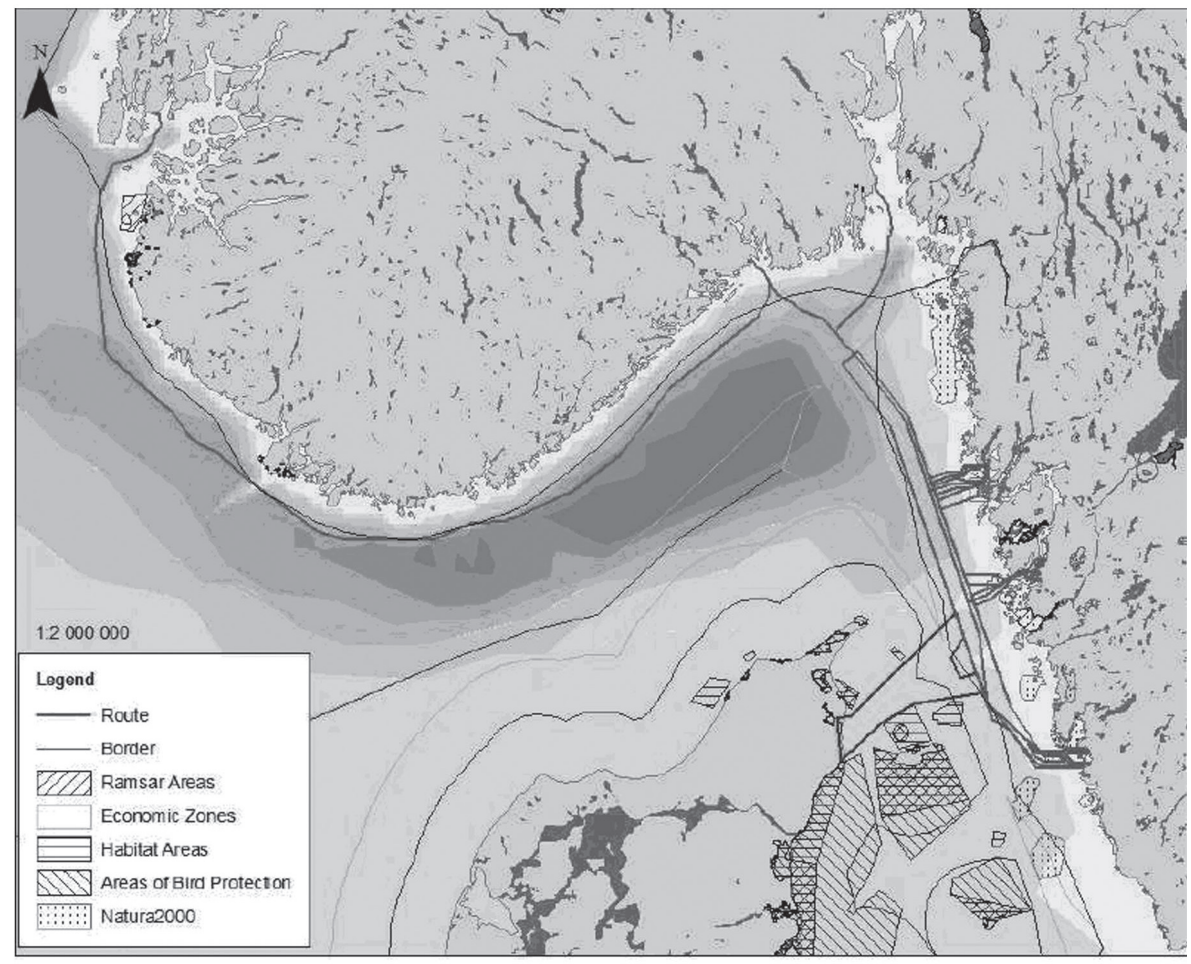

3 žemèlapis. „Skanled“ dujotiekis ${ }^{42}$

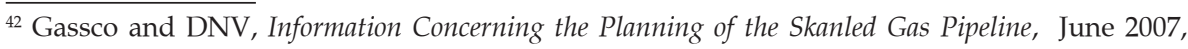
http:/ / www.energinet.dk/NR/rdonlyres/E7D26121-FE5C-46C9-9DCB-7BE95E65CD38/0/ TheSkanledgaspipelineprojectsummaryver_02_250607.pdf, 20070905. 
Lenkija gamtinių dujų importo diversifikavimo siekius sieja su gamtiniu duju importu iš Norvegijos. Lenkija dar $2001 \mathrm{~m}$. buvo sudariusi susitarimą su Danija ir Norvegija dèl "Baltic Pipe“ dujotiekio projekto igyvendinimo, kuriuo turëjo gamtinės dujos iš Norvegijos per Daniją pasiekti Lenkiją. Tačiau dèl įvairiu priežasčiu, susijusių tiek su Rusijos spaudimu, tiek su Danijos neaiškia pozicija, tiek su Lenkijos vidaus politinemis problemomis, projektas nebuvo pradètas igyvendinti. Naują impulsą Lenkijos gamtiniu dujų Skandinavijos šalyse paieškoms davė $2007 \mathrm{~m}$. pradžioje sudaryta PGNiG ir "ExxonMobil“ sutartis dèl $15 \%$ akcijų dviejuose telkiniuose Norvegijos kontinentiniame šelfe"Skarv“ ir "Snadd“ -isigijimo ${ }^{43}$. Telkinių eksploatacijos pradžia numatoma 2011 m., laikotarpis - 20-25 metai. $15 \%$ akcijų lenkams turètu garantuoti ne tiek jau ir daug duju - apie 0,2-0,6 mlrd. $\mathrm{m}^{3}$ per metus ${ }^{44}$. Toks kiekis dujų leistų tik , politiškai" diversifikuoti importa, nes jokios ịtakos gamtinių dujų importo balansui jis neturètų. Be to, vis dar išliko šių dujų atgabenimo iki Lenkijos problema.

Dèl transportavimo pajëgumu nebuvimo, Lenkija siekia prisijungti prie Skandinavijos šalių dujotiekiu infrastruktūros. $2007 \mathrm{~m}$. birželio 20 d. Lenkijos duju kompanija "Polskie Gornictwo Naftowe i Gazownictwo“ (toliau - PGNiG) prisijungè prie Norvegijos „Gassco“ vadovaujamo konsorciumo, kuris stato „Skanled" dujotiekį iš Karsto Norvegijoje į Švediją ir Daniją (žr. 3 žemèlapi). PGNiG įsigijo 15 $\%$ dujotiekio akciju $u^{45}$. Dujotiekis turètų būti pradètas statyti 2009, o veikti - 2011 metais. Jo pajejgumai turètų siekti $7 \mathrm{mlrd} . \mathrm{m}^{3}$ per metus ${ }^{46}$. Atsižvelgiant į tai, kad Karsto telkinio Norvegijoje maksimalūs gavybos pajëgumai siekia apie $9 \mathrm{mlrd} . \mathrm{m}^{3}$ duju, 2 mlrd. $\mathrm{m}^{3}$ galètų būti padidintas ir „Skanled“ pralaidumas.

2007 m. gegužès mèn. PGNiG taip pat sudarė susitarimą su Danijos „Energinet.dk“ ištirti galimybę statyti dujotieki „,Baltic Pipe“ iš Danijos į Lenkiją Baltijos jūros dugnu. „Baltic Pipe“ dujotiekis turètų sujungti „,Skanled“ dujotiekị su Lenkija, kuri turètu galimybes importuoti Norvegijos gamtines dujas. Kompanijos sutaré, kad dujotiekio projektą pirminiame etape finansuos ir jo savininku bus $\mathrm{PGNiG}^{47}$. Kaip pažymi PGNiG atstovai, „Skanled“ ir „Baltic Pipe“ dujotiekiai leis Lenkijai padidinti energetinį saugumą, pašalins dujų tiekimo sutrikimus, sumažins priklau-

\footnotetext{
${ }^{43}$ PGNiG sumokëjo $360 \mathrm{mln}$. JAV doleriu už dali telkiniuose, kuriuose, be kitu produktu, yra apie 35,8 mlrd. $\mathrm{m}^{3}$ duju. PGNiG to Acquire Stake in Norwegian Shelf Licences, http:/ / www.rigzone. com/news/article.asp?a_id=41995, 20070906.

${ }^{44}$ PGNiG Will Acquire Hydrocarbon Reserves on the Norwegian Shelf, http://reakkt.wordpress. $\mathrm{com} / 2007 / 03 / 01 /$ pgnig-will-acquire-hydrocarbon-reserves-on-the-norwegian-shelf/, 200709 06.

${ }^{45}$ Likę akcininkai yra: „E.ON Ruhrgas" - 20 \%, Skagerak Energi“ - 20 \%, „Ostfold Energi“ , „Hafslund ASA" ir „Energinet.dk" - po $10 \%$, „Agder" ir "Swedgas" - 5 \%, Goteborg Energi - 8 \%, „Preem Petroleum" - $2 \%$.

${ }^{46}$ Herron J., „Expansion Likely on Norway-Denmark Gas Pipeline“, Dow Jones Newswires, 2007 m. rugsëjo 7 d., http://www.downstreamtoday.com/News/ArticlePrint.aspx?aid=5854, 2007 0906 .

${ }^{47}$ Watson C., "Denmark and Poland Considering Gas Pipeline“, Energy Business Review Online, http:/ / www.energy-business-review.com/article_news.asp?guid=464FFA34-5CEC-4DFA-A80C5D0DC8312455, 20070906.
} 
somybę nuo vieno tiekèjo ir leis padidinti gamtinių dujų importą ${ }^{48}$. İdomu yra tai, kad kompanijos svarsto galimybę statyti dujotieki galintį veikti abiem kryptimis, $t$. y. transportuoti dujas tiek iš Danijos į Lenkija, tiek iš Lenkijos į Daniją ${ }^{49}$. Tai sudarytų galimybę ne tik Lenkijai importuoti dujas iš Norvegijos, bet ir, sumažëjus gavybos apimtims Norvegijoje, būti tranzitine valstybe Rusijos gamtinėms dujoms. Tokia perspektyva galètų tapti vienu iš argumentų Rusijai peržiūrèti ateities planus dèl gamtinių dujų eksporto maršrutų.

Lenkijos ketinimai importuoti Norvegijos gamtines dujas iš esmès neišspręs didėsiančios priklausomybès nuo Rusijos problemos. PGNiG dalis „Skarv“ ir "Snadd“ telkiniuose neužtikrins pakankamų išgaunamų dujų kiekio. Taip pat, nors ir turèdama dali ",Skanled“ dujotiekio projekte, Lenkija negalès juo transportuoti daugiau nei 1-1,5 mlrd. $\mathrm{m}^{3}$ duju per metus. Dẻl šiuc priežasčių vis dar lieka neaišku, kokias dujas Lenkija ketina importuoti „Baltic Pipe“ dujotiekiu.

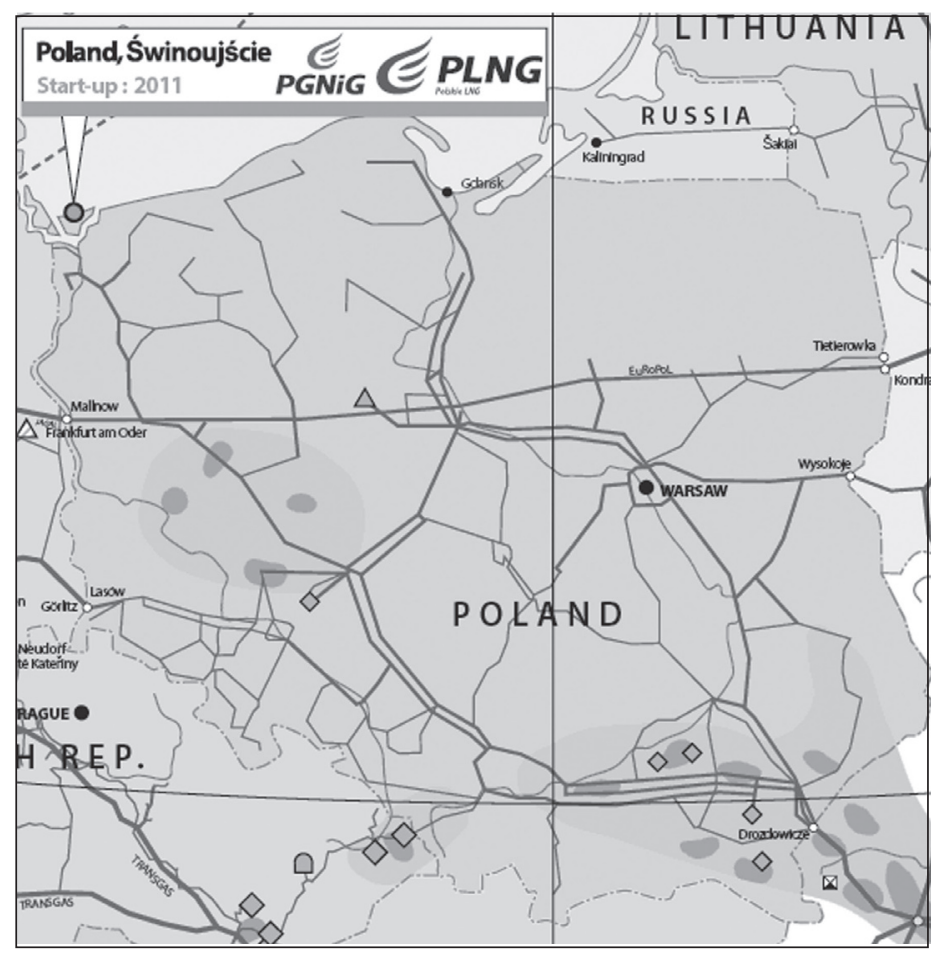

4 žemèlapis. Planuojamas suskystintų gamtinių dujų terminalas Lenkijoje ${ }^{50}$

\footnotetext{
${ }^{48}$ Polish Oil and Gas Company Joins Skanled Consortium, http://www.en.pgnig.pl/316_2414.htm, 20070906.

49 „PGNiG and Energinet.dk reached agreement on Baltic Pipe“, Scandinavian Oil-Gas Magazine, http://www.scandoil.com/moxie-bm2/news/contracts_world/pgnig-and-energinetdk-rea. shtml, 20070906.

${ }^{50}$ LNG Map. Information by Entry Point, http:/ / www.gie.eu.com/download/gridmap/GLE_LNG_ 207.pdf, 20070810.
} 
Dar viena Lenkijos energetinio saugumo stiprinimo gamtinių duju srityje kryptis yra SGD importo terminalo statyba. Tokio terminalo Gdanske projektas yra minimas Pirmenybinio sujungimo plane prie NG4 prioritetinès ašies projektų. 2005-2006 m. buvo manoma, kad $500 \mathrm{mln}$. eurų vertės 3-5 mlrd. $\mathrm{m}^{3}$ pajègumo terminalas bus pradètas statyti jau $2007 \mathrm{~m}$. ir pradès veikti 2010 metais $^{51}$. Tačiau $2006 \mathrm{~m}$. PGNiG paskelbẻ konkursą atlikti SGD terminalo statybos Lenkijoje galimybiu studiją. Buvo vertinamos dvi galimybès - statyti terminalą Gdanske (Pirmenybinio sujungimo plane minimas projektas) ir Svinouščje uoste (žr. 4 žemèlapi), esantį šalia Lenkijos ir Vokietijos sienos (300 km į Vakarus nuo Gdansko). PGNiG pasirinko antraji variantą, nes, pirma, SGD tanklaiviams reikètų plaukti mažesnį atstumą nei iki Gdansko, antra, Šiaurès Rytiniai Lenkijos regionai yra mažiau dujofikuoti, trečia, regiono elektrinès galès pereiti nuo anglies prie gamtiniu dujų vartojimo ${ }^{52}$, ketvirta, tinkamesnè uosto infrastruktūra ${ }^{53}$. Akivaizdu, kad galimos gamtiniu dujų reeksporto galimybès į Lietuvą nebuvo tarp pasirinkimo kriterijų.

Numatytas terminalo bazinis pajėgumas sieks $2,5 \mathrm{mlrd} . \mathrm{m}^{3}$ per metus, vèliau jis bus didinamas iki 5 ir 7,5 mlrd. kubiniu metru ${ }^{54}$. Toks kiekis gamtinių dujų leistų Lenkijai diversifikuoti importą ir aprūpinti dujomis Šiaurès vakaru regionu pramonès objektus. Lietuvos prisijungimas prie šio projekto, net neturint jo ekonominio pagrindimo analizès, yra sunkiai igyvendinamas vien dèl dujotiekio tiesimo kainos (priklausomai nuo sąlygu, apie $1 \mathrm{mln}$. euru už dujotiekio kilometrą), kurios našta Lenkijos kompanijos nežinia ar sutiktu dalytis vien tik vardan "strateginès partnerystès". Be to, jei Lietuvos įmonès būtų pajėgios investuoti tokią sumą į dujotiekị, ekonomiškai efektyviau būtu statyti tokị terminalą Lietuvoje.

\footnotetext{
${ }^{51}$ Signing of a Letter of Intent Regarding the Construction of the Maritime Gas Terminal in the Port of Gdansk, http:/ / www.portgdansk.pl/events/a-letter-of-intent-regarding-the-construction-of-thelng-terminal, 20070810.

${ }^{52}$ Jeziorski M., „Alternative Access“, The Warsaw Voice, 2006 m. sausio 18 d., http:/ /www.warsawvoice.pl/view/10305, 20070810.

${ }^{53}$ Management Board of PGNiG selects the Location for LNG Terminal on the Polish Coast, http: / / www. en.pgnig.pl/cp/news/478_2208.htm, 20070810.

${ }^{54}$ Poland Moves in New Directions Regarding Liquid Natural Gas Import, http:/ /www.ilf.de/index. php?id=63\&L=1\&tx_ttnews\%5Btt_news\%5D=131\&tx_ttnews $\% 5 B$ backPid $\% 5 \mathrm{D}=18 \& c H a s h=b 67$ 5b13948, 20070810.
} 


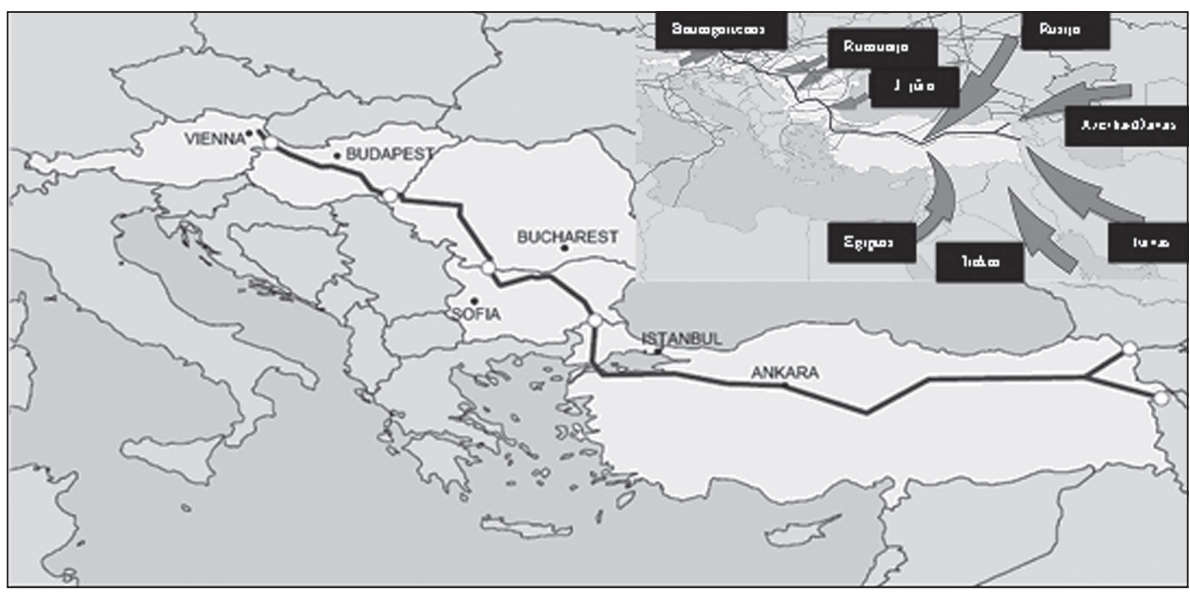

5 žemèlapis. „Nabucco“ dujotiekio maršrutas ir galimi gamtinių dujų šaltiniai ${ }^{55}$

Trečioji minima galimybė Lietuvai yra prisijungti prie Kaspijos jūros gamtines dujas tiekiančių dujotiekių Lenkijoje. Siuo metu vienintelis bent kiek tikresnis gamtinių dujų tiekimo iš Kaspijos jūros baseino į Europą projektas yra "Nabucco" dujotiekio projektas ${ }^{56}$. Dujotiekis turètu sujungti Kaspijos jūros baseino ir Artimujų Rytų gamtinių dujų tiekëjus per Turkiją, Bulgariją, Rumuniją, Vengriją ir Austriją su Vakarų Europos gamtinių dujų rinka. Vamzdyno ilgis turètu siekti $3300 \mathrm{~km}$, pajègumas $-31 \mathrm{mlrd} . \mathrm{m}^{3}$, kaina $-5 \mathrm{mlrd}$. euru ${ }^{57}$. Dujotiekio pradžia numatoma ties Turkijos-Gruzijos siena ir ties Turkijos-Irano siena, pabaiga - Baumgarteno dujotiekių mazgas Austrijoje. Projekto pagrindime nurodomi keturi strateginiai dujotiekio tikslai: pirma, sukurti naują duju tiekimo koridoriu ic Europą ir ì projektą įsitraukusias šalis, antra, padidinti valstybiu, per kurias drieksis dujotiekis, tranzitinę reikšmę, trečia, padidinti projekte dalyvaujančiu valstybių ir visos Europos tiekimo saugumą ir, ketvirta, sustiprinti projekte dalyvaujančių valstybių dujotiekių tinklų jungtis su Euro-

\footnotetext{
${ }^{55}$ Nabucco Gas Pipeline International GmbH, Nabucco Gas Pipeline Project. Gas Bridge Between Caspian Region/Middle East/ Egypt and Europe, February 2007, http:/ /www.nabucco-pipeline.com/cms / upload/Partner_Logos/Nabucco_presentation_web_Feb_2007.pdf, 20070705.

${ }^{56} 2002$ m. "Nabucco" dujotiekio idejją parengė Austrijos ir Turkijos energetikos kompanijos - OMV ir BOTAS. Vèliau prie ju prisijungè Bulgarijos „Bulgargaz", Rumunijos „Transgaz" ir Vengrijos MOL. Šios penkios kompanijos 2002 m. spalio mẻn. pasirašẻ bendradarbiavimo susitarimą, kuriame numatė atlikti projekto galimybiu studiją. 2003 m. Europos Komisija sudarė finansavimo susitarimą su dujotiekio statyba suinteresuotomis kompanijomis ir įsipareigojo padengti $50 \%$ galimybių studijos lëšų. Galimybių studijos išvados teigè, kad toks dujotiekis pagal techniką ir pagal ekonomiką yra pagrịstas. $2005 \mathrm{~m}$. birželio mèn. 5 kompanijos pasirašè susitarimą dèl bendros įmonès dujotiekio statybai steigimo. Vamzdyno statyba turètu prasidèti 2009 m., o dujos juo tekèti turètu pradèti - 2012 metais.

${ }_{57}$ Nabucco Project Description, http:/ / www.nabucco-pipeline.com/project/project-descriptionpipeline-route/index.html, 20070705.
} 
pos dujotiekių tinklu ${ }^{58}$. „Nabucco“ turètų sujungti milžiniškus gamtinių duju telkinius su nepasotinama Europos gamtinių dujų rinka per Juodosios jūros regioną ir sutvirtinti Vidurio Europos kaip tranzito erdvės reikšmę.

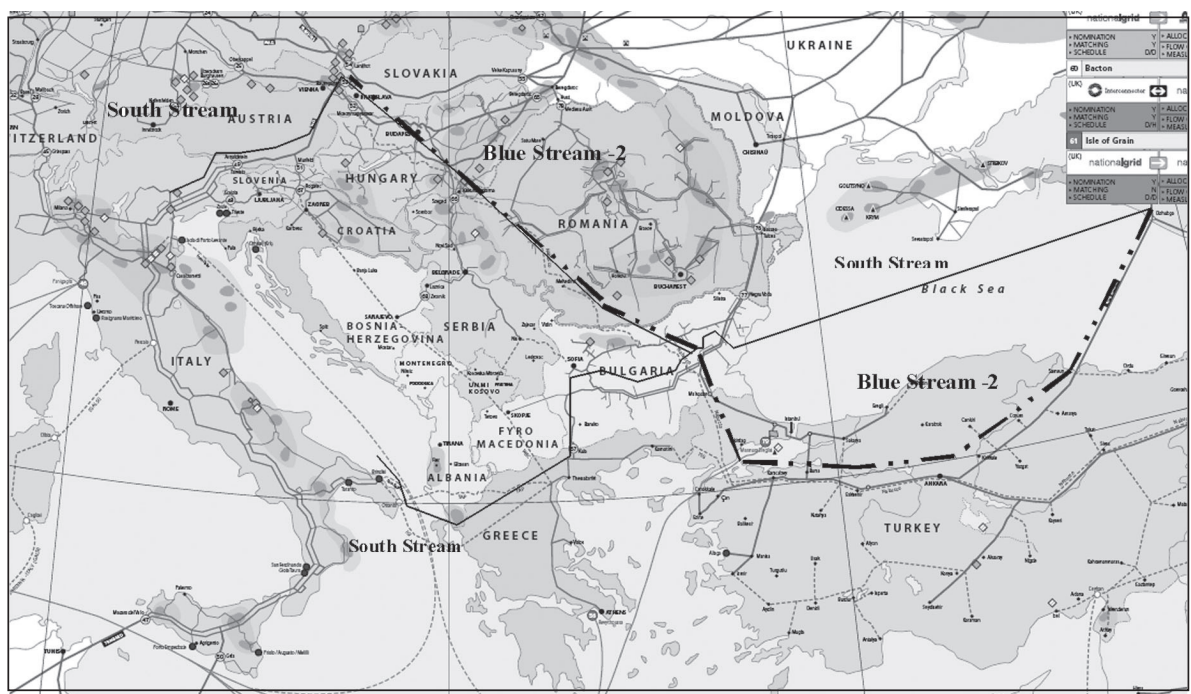

6 žemèlapis. Konkuruojantys su „Nabucco“ dujotiekiai59

Tačiau visame „Nabucco“ projekte trūksta pagrindinės grandies - tiekimo. Visos penkios projekte dalyvaujančios kompanijos atstovauja tranzito ir vartojimo valstybėms - nėra kompaniju, kurios išgauna pakankamą kieki gamtinių duju Kaspijos jūros baseine ar Artimuosiuose Rytuose. Tai yra svarbiausias iššūkis dujotiekiui, prie kurio norètu prisijungti ir Lenkija. Antras iššūkis "Nabucco“ dujotiekiui yra alternatyvūs projektai regione, kuriuos inicijavo ir siekia igyvendinti gamtinių duju tiekimą garantuojanti Rusija. Šie konkuruojantys projektai yra: pirmasis - „Žydrosios srovès“ dujotiekio iš Rusijos i Turkiją Juodosios jūros dugnu pratęsimas ị Vidurio Europą - projektas "Žydroji srovė 2“; antrasis - „Gazprom“ ir Italijos ENI remiamas dujotiekis iš Rusijos į Bulgariją Juodosios jūros dugnu, iš kurios pasieks Italiją - „South Stream“ (žr. 6 žemèlapì). Be didelès ES politinès paramos "Nabucco“ dujotiekiui, jo pozicijos yra silpnesnès jau vien todèl, kad Rusija, siūlydama analogiško pajejgumo dujotiekiu projektus, pirma, siūlo ir gamtines dujas, antra, yra užsitikrinusi potencialių pirkëju Vakaruose paramą, trečia, yra pajejgi pervilioti į savo pusę svarbiausias tranzito valstybes (Bulgariją ",South Stream“ atveju ar Vengriją "Blue Stream 2“ projekte).

Jei kuris nors, išskyrus Rusiją, tiekejjas (ar tiekejjai) įsipareigotų $2020 \mathrm{~m}$. visiškai užpildyti „Nabucco“ (30 mlrd. $\left.\mathrm{m}^{3}\right)$, nèra jokių garantiju, kad šios dujos

${ }^{58}$ Nabucco Project. Mission Statement/Strategic Goals, http:/ / www.nabucco-pipeline.com/company/mission-statement-strategic-goals/index.html, 20070705.

${ }^{59}$ Operational Procedures at major cross-border interconnection points. 
kada nors pasieks Lenkiją. Pirma, Lenkijos kompanijos nedalyvauja projekte. Antra, dalis transportuojamu dujų liks tranzito valstybėse, todèl nèra aišku, kiek jų Baumgartene liks laisvų parduoti kitoms šalims. Trečia, Lenkijos ir Čekijos (iki kurios galètų pasiekti dujos iš Austrijos) dujotiekių jungtys nèra pakankamos, todèl reikètų statyti naujus vamzdynus. Jei „Nabucco“ būtų pastatytas, o juo tiekiamų dujų užtektų ir Lenkijai (be to, ju kaina būtų palanki statyti dujotiekį), labai abejotina, kad jų dar liktų ir Lietuvai. Atsižvelgiant į tai, kad Baumgarteno dujų saugyklos Austrijoje (kur turètų baigtis „Nabucco“) turi puikias jungtis su Vakarų Europos dujotiekių infrastruktūra, bet koks tolimesnis dujų transportavimas, tiesiant naujus vamzdynus būtų nekonkurencingas. Dẻl šiu priežasčių Lietuvos viltys per Lenkiją importuoti Kaspijos dujas yra nepagrįstos. Jei Lietuva turètų galimybių tapti gamtinių dujų tranzito į Vakarų Europą šalimi, jai energetinio saugumo požiūriu „Nabucco“" projektas net būtų žalingas, nes sustiprintų Pietryčių Europos reikšmę gamtinių dujų tranzitui ir susilpnintų Vidurio ir Šiaurès Rytų Europos pozicijas prekyboje energetiniais ištekliais.

\section{Lietuvos ir Lenkijos santykiai elektros energetikos sektoriuje}

\subsection{Lietuvos ir Lenkijos elektros energetikos ūkių skirtumai}

Lietuvos ir Lenkijos elektros energetikos sektoriai skiriasi elektros energijos gamybos šaltiniais. Lietuvoje daugiau nei $70 \%$ visos elektros energijos pagaminama Ignalinos atominejje elektrinejje (toliau - Ignalinos AE). Lenkijoje elektros energijos gamyboje vyrauja anglis - daugiau nei $90 \%$ pirminių šaltinių. Antras skirtumas - Lenkija nuo $2001 \mathrm{~m}$. yra Elektros perdavimo koordinavimo sajungos (ang. Union for the Coordination of Transmission of Electricity, toliauUCTE) narè (tinklus sujungè 1995 metais). UCTE vienija beveik visų Vakaru ir Vidurio Europos valstybiu tinklus. Lenkija taip pat turi jungtis su UPS/IPS tinklo, vienijančio visas buvusias Sovietų Sąungos respublikas, narèmis Ukraina ir Baltarusija. Lietuva yra prijungta tik prie UPS/IPS tinklo ir neturi prisijungimo prie Vakarų Europos. Vienintelè Lietuvos sąsaja su Lenkija yra per Baltarusiją, kuri turi dvi jungtis su Lenkija.

Pagrindinis elektros energetikos sektoriuc panašumas yra tai, kad tiek Lietuva, tiek Lenkija yra elektros energijos eksportuotojos (žr. 3 lentelę). Tačiau jų negalima laikyti konkurentemis, nes šalys parduoda elektros energiją skirtingoms rinkoms ir nèra tarpusavyje sujungtos. Lietuva daugiausia elektros energijos 2006 m. eksportavo į Latviją (0,7 TWh), Baltarusiją (0,63 TWh) ir Rusiją (0,46 TWh), importavo - iš Rusijos (1,39 TWh) ${ }^{60}$. Lenkija yra šešta ir beveik

\footnotetext{
${ }^{60}$ Lietuvos Respublikos ūkio ministerija, Tiekimo saugumas Lietuvos elektros energijos rinkoje. Monitoringo ataskaita, 2007, http:/ / www.ena.lt/pdfai/Monitoringas_2007.pdf, 20070906.
} 
didžiausia ES elektros energijos eksportuotoja ${ }^{61}$. 2005 m. Lenkija daugiausia elektros energijos eksportavo į Čekiją (11,1 TWh), Slovakiją (2,8 TWh), Svediją (1,2 TWh) ir Vokietiją (1 TWh), importavo daugiausia iš Vokietijos (2,3 TWh), Ukrainos (1 TWh), Baltarusijos (0,9 TWh) ir Švedijos (0,8 TWh $)^{62}$.

3 lentelè. Elektros energijos sektoriaus struktūra Lietuvoje ir Lenkijoje, TWh $^{63}$

\begin{tabular}{|c|c|c|c|c|c|c|c|c|c|c|}
\hline & \multicolumn{5}{|c|}{ Lietuva } & \multicolumn{5}{|c|}{ Lenkija } \\
\hline & ષ્ત & ஜి & ఫి & 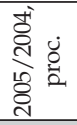 & 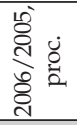 & ఫ্ণ & ஜి & §ัి & 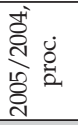 & 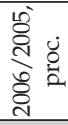 \\
\hline Gamyba & 17,7 & 13,6 & 11,0 & $-23,2$ & $-19,1$ & 140,8 & 143,6 & 147,3 & 2,0 & 2,6 \\
\hline $\begin{array}{l}\text { Konvencinė } \\
\text { šiluminė }\end{array}$ & 2,7 & 3,0 & 2,5 & 11,1 & $-16,7$ & 137,0 & 139,7 & 144,0 & 2,0 & 3,1 \\
\hline Branduolinè & 13,9 & 9,5 & 7,9 & $-31,7$ & $-16,8$ & & & & & \\
\hline $\begin{array}{l}\text { Hidro } \\
\text { energija } \\
\text { ir kita }\end{array}$ & 1,1 & 1,1 & 0,6 & & $-45,5$ & 3,8 & 3,9 & 3,3 & 2,6 & $-15,4$ \\
\hline Importas & 4,3 & 5,6 & 5,8 & 30,2 & 3,6 & 5,3 & 5,0 & 4,8 & $-5,7$ & $-4,0$ \\
\hline Eksportas & 11,5 & 8,6 & 6,2 & $-25,2$ & $-27,9$ & 14,6 & 16,2 & 15,8 & 11,0 & $-2,5$ \\
\hline $\begin{array}{l}\text { Energijos } \\
\text { praradimai }\end{array}$ & 0,7 & 0,5 & 0,6 & $-28,6$ & 20,0 & 2,3 & 2,2 & 1,6 & $-4,3$ & $-27,3$ \\
\hline Vartojimas & 9,8 & 10,1 & 10,0 & 3,1 & $-1,0$ & 129,2 & 130,2 & 134,7 & 0,8 & 3,5 \\
\hline \multicolumn{11}{|c|}{ Elektros energijos gamybos šaltiniai, $\%$} \\
\hline $\begin{array}{l}\text { Konvencinė } \\
\text { šiluminé }\end{array}$ & 15,3 & 22,1 & 22,7 & & & 97,3 & 97,3 & 97,8 & & \\
\hline Branduolinè & 78,5 & 69,9 & 71,8 & & & & & & & \\
\hline $\begin{array}{l}\text { Hidro ir } \\
\text { kita }\end{array}$ & 6,2 & 8,1 & 5,5 & & & 2,7 & 2,7 & 2,2 & & \\
\hline
\end{tabular}

Lenkija yra didžiausia elektros energijos gamintoja ir vartotoja visoje Vidurio Europoje. Nors prognozuojama, kad ateityje išaugs elektros energijos vartojimas, reikès uždaryti arba renovuoti senstančias anglimi kūrenamas elektrines, Lenkija turès pakankamą elektros galios rezervą ir išliks elektros

\footnotetext{
${ }^{61}$ Panorama of the European Union. Gas and Electricity Market Statistics, 2006 Edition, Luxembourg: Office for Official Publications of the European Communities, 2006, http:/ / ep.eurostat.ec.europa. eu/cache/ITY_OFFPUB/KS-76-06-289/EN/KS-76-06-289-EN.pdf, 20070822.

${ }^{62}$ UCTE, Statistical Yearbook 2005, http://www.ucte.org/_library/statsyearbook/Statistical_Yearbook_2005.pdf, 20070903.

${ }_{63}^{63}$ Bassan M., "Electricity Statistics - Provisional data for 2006,. Eurostat Data in Focus, 4/2007, http:/ / epp.eurostat.ec.europa.eu/cache/ITY_OFFPUB/KS-QA-07-004/EN/KS-QA-07-004EN.PDF, 20070802.
} 
energijos eksportuotoja ${ }^{64}$. Lietuva elektros energijos eksportuotoja išliks tik iki Ignalinos atominès elektrinès uždarymo - $2009 \mathrm{~m}$. pabaigos. Nacionalinëje energetikos strategijoje teigiama, kad, uždarius antraji Ignalinos AE bloką, turimu generuojančiu galiu, įskaitant planuojamas pastatyti nedidelès galios termofikacines elektrines, pakaks iki 2013 metu $^{65}$. Tačiau elektros energiją Lietuvai gali tekti importuoti jau anksčiau, nes Lietuvos elektrinëje gaminamos elektros energijos kaina bus nekonkurencinga. Lietuva iš elektros energijos eksportuotojos taps elektros energijos importuotoja. Šiuo metu labiausiai tikètinas importuojamos elektros tiekèjas yra Rusija (nors svarstomos galimybès importuoti elektros energiją ir iš kitų UPS/IPS sistemos šalių, pavyzdžiui, $\mathrm{Ukrainos}^{66}$ ), o tai dar labiau padidins Lietuvos energetikos ūkio priklausomybę nuo Rusijos. Lietuvos priklausomybè nuo elektros energijos importo iš vieno šaltinio (neturint jungčių su Skandinavijos šalimis ir/ar Lenkija), Lietuvos nacionalinėje strategijoje įvardijama kaip grèsmė stabiliam apsirūpinimui elektros energija.

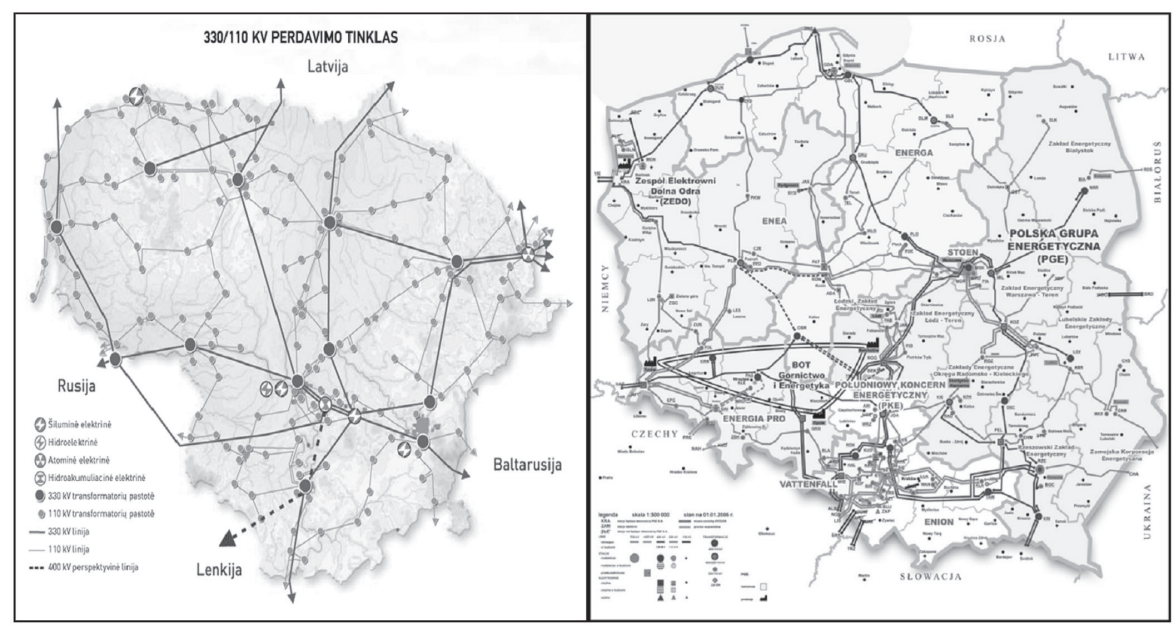

7 žemèlapis. Lietuvos ir Lenkijos elektros perdavimo tinklai ${ }^{67}$

\footnotetext{
${ }^{64}$ Plačiau žr. R. Deksnys (darbo vadovas), Atominés elektrinés konkurencingumo Baltijos, Skandinavijos, Vakaru Europos šaliu ir Rusijos elektros energijos rinkose analize (galutine ataskaita), Kauno technologijos universiteto Elektros ir valdymo inžinerijos fakulteto Elektros sistemų katedra, $2005 \mathrm{~m}$. gruodžio $1 \mathrm{~d}$.

${ }^{65}$ Nutarimas dèl Nacionalinés energetikos strategijos patvirtinimo.

${ }^{66}$ Apie tikslingumą išnagrinèti elektros energijos importo iš Ukrainos per Baltarusiją galimybes žr. Ten pat.

${ }^{67}$ 330/110kV perdavimo tinklas, http://www.lietuvosenergija.lt/lt/main/system/network, 200708 15. Polish Energy Group, http://www.pse.pl/galeria/pge_01.jpg, 20070815.
} 


\subsection{Bendri Lietuvos ir Lenkijos projektai elektros energetikos srityje}

Siekiant sumažinti grėsmes energetiniam saugumui elektros energijos ūkyje, Nacionalinëje energetikos strategijoje be kitų priemonių (naujų termofikacinių elektrinių statyba, senų elektrinių renovavimas, elektros energijos perdavimo tinklų Lietuvoje stiprinimas ir kt.) yra numatyti šie uždaviniai: pirma, ne vèliau kaip 2015 m. pradèti eksploatuoti naują atominę elektrinę Lietuvoje. Antra, iki naujos atominès elektrinės veiklos pradžios ir ne vèliau kaip iki 2012 m. sujungti Lietuvos aukštos įtampos elektros tinklus su Skandinavijos šaliu ir Lenkijos tinklais - „visomis galimomis ekonominemis ir politinėmis priemonemis būtina skatinti ir kuo skubiau pastatyti galingas jungtis su Lenkijos ir Švedijos elektros energetikos sistemomis" "68. Trečia, iki 2015 m. igyvendinti technines priemones, reikalingas Lietuvos elektros energetikos sistemos sinchronizuotam darbui su UCTE sistema. Visų šių uždavinių igyvendinimas yra neatsiejamas nuo Lietuvos ir Lenkijos bendradarbiavimo.

\subsubsection{Elektros tiltas tarp Lietuvos ir Lenkijos}

Lietuvos planai sujungti elektros tinklus su Lenkija gyvuoja nuo 1993 m., tačiau iki šiol tilto statyba nèra pradèta. Lietuvai tinklų sujungimas su Lenkija yra strategiškai svarbus, nes, pirma, padidintų tiekimo patikimumą Lietuvoje - sudarytų sąlygas stabiliam elektros energijos importui uždarius Ignalinos AE. Antra, leistu prisijungti prie ES vidaus elektros energetikos rinkos. 2003 m. Europos rekonstrukcijos ir pletros banko finansuotoje studijoje, kurioje ivvertinamos projektui reikalingos investicijos ir finansavimui būdai, teigiama, kad Lietuvos ir Lenkijos elektros tinklus tikslinga sujungti dvigrande $400 \mathrm{kV}$ 1000 MW pralaidumo elektros linija su nuolatinès srovės intarpu ${ }^{69}$. Lenkijos puse vilkino statybos darbu pradžią, nes baiminosi Ignalinos AE pagamintos pigios elektros energijos konkurencijos iš Lietuvos. Vèliau, kai buvo priimtas sprendimas dèl Ignalinos AE uždarymo ir lyg turëjo išnykti „pigios lietuviškos energijos" grèsmė, Lenkijos energetikai vilkino projektą, nes manė, kad per Lietuvą Lenkiją pasieks pigi Rusijos elektros energija ${ }^{70}$. Elektros energijos generavimo kompanijoms Lenkijoje dèl padidejusios konkurencijos būtų sudètinga užsitikrinti plètrą, o tai pakirstų Lenkijos, kaip elektros energijos eksporto valstybės, pozicijas. Lenkijai nèra naudinga, kad Lietuva taptų elektros energijos tranzito šalimi į Lenkiją, nes tai keltų grèsmę šalies energetiniam

\footnotetext{
${ }^{68}$ Nutarimas dél Nacionalinés energetikos strategijos patvirtinimo.

${ }^{69}$ Projekto kaina tuo metu buvo įvertinta $434 \mathrm{mln}$. eurų. Siekiant, kad projektas būtų komerciškai tikslingas, jo igyvendinimui reikia ES finansinės paramos - $267 \mathrm{mln}$. eurų. Juozaitis R., Ilgas lietuviškos elektros kelias $\dot{i}$ Vakarus, http:/ / neris.mii.lt/mt/straipsniai/20055/ilg.doc, 20070909.

${ }^{70}$ Komaras J. J., „Lenko pozicija: kodèl nèra elektros tilto į Vakarus?“ , Lrytas.lt, 2006 m. kovo 14 d., http: / / www.lrytas.lt/?id=11422625581141696756\&view=4, 20070115.
} 
saugumui (nepriklausomumui elektros energetikos sektoriuje). Lenkijai elektros tiltas yra ne Lietuvos ir Baltijos valstybių vartai į Vakarų Europą, bet Rusijos vartai į Lenkiją.

Tačiau Lietuvos ir Lenkijos elektros jungtis nèra vien dvišalis klausimas. Sujungus šalių tinklus būtų užbaigtas Baltijos žiedas, apimantis Baltijos valstybes, Skandinavijos šalis ir Lenkiją bei Vokietiją. Dėl šios priežasties elektros tilto projektas buvo įtrauktas į ES Pirmenybinio sujungimo planą. UCTE plètra į Rytus yra laikoma reikšminga galimybe ES padidinti prekybą elektros energija ir perdavimo pajejgumus ${ }^{71}$. To nebus galima pasiekti neprijungus Baltijos valstybiu prie UCTE, todèl elektros tiltas ES yra svarbus ne tik dèl vidaus elektros energijos rinkos plètros, bet ir kaip ES prekybos su kaimynèmis priemonè.

Kita vertus, ne Baltijos valstybès ir Lietuva turètų tapti pagrindiniu elektros energijos iš UPS/IPS sistemos iz UCTE tranzito koridoriumi. Tokia perspektyva nusimato pačiai Lenkijai. Europos Komisija prognozuoja, kad 2030 m. apsikeitimas tarp ES-Baltarusijos, Ukrainos ir Rusijos sieks 40 TWh per metus, o tarp Baltijos valstybiu, Suomijos ir Rusijos - 30 TWh. Didžioji dalis šio kiekio į Vakarų Europą ir iš jos (jei Rusijoje bus elektros energijos deficitas) keliaus per Lenkiją ${ }^{72}$. Pagrindinis skirtumas tarp Lietuvos-Lenkijos elektros tilto ir UCTE ir UPS/IPS sistemų plataus sujungimo yra tai, kad, igyvendinus tik elektros tilto projektą, Lietuva taptų elektros energijos tranzito šalimi, o Lenkija - potencialia jos vartotoja. UCTE sujungus su UPS/IPS ne tik per Baltijos valstybes, bet ir per Baltarusiją ir Ukrainą, taip pat padidinus perdavimo tinklu Lenkijoje galią, tranzito valstybe taptų Lenkija, o elektros energijos vartotojai - kitos Vidurio ir Vakarų Europos šalys. Todèl greičiausiai ir buvo priimtas sprendimas Lietuvos ir Lenkijos elektros tilto projektą išplèsti ir į ji įtraukti Lenkijos ir Vokietijos jungčių bei Lenkijos elektros tinkluc plètrą73. Lietuvos ir visų Baltijos valstybiu prisijungimo prie Vakarų Europos energetikos tinklu sąskaita Lenkija siekia išspręsti ir savo elektros energetikos sektoriaus problemas, neutralizuodama galimas grėsmes energetiniam saugumui. Tačiau net projekto išplètimas nepadëjo greičiau jo iggyvendinti.

\footnotetext{
${ }^{71}$ European Commission, Directorate-General for Research, Energy Corridors. European Union and Neighbouring Countries, 2007, http://www.ecn.nl/docs/library/report/2007/b07016.pdf, 2007 0820.

${ }^{72}$ Ten pat.

${ }^{73}$ Toks projektas yra įtrauktas ị Pirmenybinio sujungimo planą. Žr. Priority Interconnection Plan.
} 


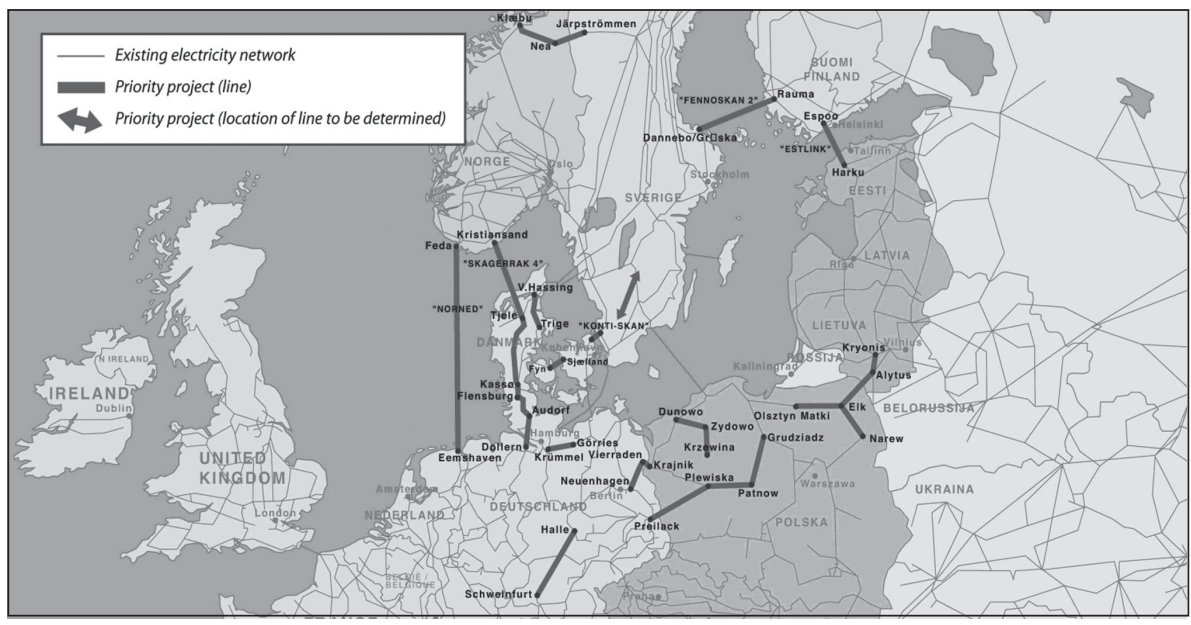

8 žemèlapis. Danijos, Vokietijos, Baltijos žiedas ${ }^{74}$

Lietuvą ir Lenkiją jungiančios elektros perdavimo linijos, įskaitant Lenkijos elektros perdavimo ir paskirstymo sistemos modernizavimą (plečiant jungtis Lenkija-Vokietija), projektas buvo įtrauktas į ES Pirmenybinio sujungimo planą kaip „,svarbi jungtis, leisianti Baltijos šalių elektros energijos perdavimo ir paskirstymo sistemas sujungti su UCTE tinklu“"75. Projektas buvo priskirtas prie EL7 ašies: Danija-Vokietija-Baltijos žiedas (žr. 8 žemėlapi). Prie projekto taip pat yra nurodytos ir kliūtys jo igyvendinimui: pirma, koordinavimo stoka ir nepakankama politinė parama praeityje, antra, pakeistas projekto pobūdis - jo išplètimas, trečia, neapibrèžtumas, kylantis dèl skirtingų sinchronizavimo rajonu, ketvirta, Lenkijos energijos perdavimo ir paskirstymo sistemos stabilumas, penkta, elektros perdavimo linija būtų tiesiama per gamtiniu atžvilgiu saugomą teritoriją, šešta, siekiant visuomenės reikmėms nusavinti žemę, kuria būtų tiesiama elektros linija, Lenkijoje reikètų keisti įstatymus, septinta, reikia kryžmiškai sujungtos transformatorių pastotės. Dalis šių problemų yra technikos, tačiau dalis jų neišvengiamai yra susiję su ,,strateginès partnerystės dvasia": politinės valios stoka, istatymu keitimu, aplinkos saugos problemu sprendimu ir kitos. Europos Komisija 2007 m. rugsëjo mėn. net paskyrẻ koordinatorių energijos tilto tarp Lietuvos, Lenkijos ir Vokietijos statybai, kaip sunkiai igyvendinamam Europos intereso projektui ${ }^{76}$. Beje, sunkiausia igyvendinama

${ }^{74}$ Priority Projects for Electricity, http:/ /ec.europa.eu/ten/energy/studies/doc/2004_brochure/ electricity_network_07_en.jpg, 20070812.

${ }^{75}$ Priority Interconnection Plan.

${ }^{76}$ BNS, Europos Komisija paskyré koordinatoriu energijos tilto iš Lietuvos i Lenkija projektui, $2007 \mathrm{~m}$. rugsëjo 13 d., http://www.euro.lt/lt/naujienos/apie-lietuvos-naryste-europos-sajungoje/ naujienos/1471/?print=1, 20070913. 
projekto dalimi Europos Komisija įvardija linijos Alytus-Elkas statybą ${ }^{77}$. Tačiau didžiausia projekto problema yra ne koordinacijos stoka, bet nesuderinamumas su Lietuvos ir Lenkijos geoenergetiniais interesais.

2007 m. liepos mèn. „Lietuvos energija“ ir „Polskie Sieci Elektroenergetyczne" pasirašytoje galutineje elektros energijos tinklų sujungimo galimybiu studijoje teigiama, kad linija kainuos 818,3 mln. litų ir ją statyti apsimokès, jei ES finansuotų $75 \%$ projekto igyvendinimo. Perdavimo galios ir tarpsisteminiu srautų tarp abiejų šalių užtikrinimui būtinos papildomos investicijos: 1,28 mlrd. litų Lenkijoje ir $328 \mathrm{mln}$. litų Lietuvoje ${ }^{78}$. Investicijas vidaus tinklu plètrai turès užtikrinti pačios projekto šalys, t. y. elektros energijos kompanijos „Lietuvos energija“ ir "Polskie Sieci Elektroenergetyczne“. Jei Lenkija toliau laikysis pozicijos, kad nepradès elektros tilto statybos nemodernizavusi vidaus tinklu, jo statyba gali taip ir neprasidèti. Taip pat Lenkija turès svertą santykiuose su Lietuva, leidžiantị daryti spaudimą dèl kitų klausimu, kurie gali būti tiek susiję su energetikos sektoriumi, tiek nesusiję.

\subsubsection{Naujos atominès elektrinès Lietuvoje statyba}

Dar vienas svarbus Lietuvos energetinio saugumo stiprinimo projektas yra naujos atominės elektrinės Lietuvoje statyba. Šis uždavinys yra numatytas Nacionalineje energetikos strategijoje. Lietuvos Respublikos Seimas 2007 m. birželio mėn. prièmė Atominės elektrinès ịstatymą ${ }^{79}$, kuriuo pritarẻ jos statybai ir nurodè, kad elektrinę statys projekto igyvendinimo bendrovè, kurioje Lietuvos nacionaliniam investuotojui turi priklausyti ne mažiau $34 \%$ akciju. Šiuo i̊statymu buvo padèti atominès energetikos tęstinumo Lietuvoje pagrindai.

Atominès elektrinès projekto pradžia galima laikyti $2006 \mathrm{~m}$. vasario mèn. Lietuvos, Latvijos ir Estijos vyriausybiu vadovų komunikatą, kuriuo jie išreiškè pritarimą naujos elektrinès statybai ir pakvietè nacionalines kompanijas investuoti i projektą. Po kelių savaičiu, 2007 m. kovo 8 d. „Lietuvos energija“, "Latvenergo" ir "Eesti Energia“ vadovai pasirašè susitarimo memorandumą dèl naujos elektrinės statybos igyvendinamumo studijos rengimo. Baltijos valstybių vadovai ir energetikai yra suinteresuoti naujos elektrinės statyba, nes po Ignalinos AE uždarymo visos trys šalys pajus elektros energijos deficitą ir turès arba didinti importą iš Rusijos (tuo pačiu ir priklausomybę), arba investuoti i nauju elektrinių statymą savo šalyse. Atlikus projekto igyvendinamumo stu-

\footnotetext{
${ }_{77}$ European Commission, Directorate-General for Transport and Energy, Trans-European Energy Networks, 1st TEN-E Information Day, 2007 March 30, http:/ / ec.europa.eu/ten/energy/documentation/doc/2007_03_30_ten_e_infoday_presentation_en.pdf, 20070815.

${ }^{78}$ BNS, Lietuvos ir Lenkijos elektros tiltas apsimokés, jei ES dengs 75 proc. investiciju, $2007 \mathrm{~m}$. liepos $31 \mathrm{~d} .$, http:/ / www.euro.lt/lt/naujienos/apie-lietuvos-naryste-europos-sajungoje/naujienos/1219/, 20070802.

${ }^{79}$ Žr. Lietuvos Respublikos Seimas, Lietuvos Respublikos atominés elektrinés isstatymas, X-1231, $2007 \mathrm{~m}$. birželio 28 d., http:/ / www3.lrs.lt/pls/inter3/dokpaieska.showdoc_l?p_id=301267, 20070710.
} 
diją, buvo prieita išvados, kad, palyginus su kitomis alternatyvomis, Ignalinos AE pakeitimas nauja atomine elektrine yra priimtiniausias, nes leistų išlaikyti elektros energijos gamybai naudojamų kuro rūšių ir įvairių generavimo šaltinių įvairovę, padidintų tiekimo saugumą, leistų sumažinti aplinkos taršą, taip pat projektas yra įmanomas ir finansiniu požiūriu ${ }^{80}$. Studijoje buvo siūloma statyti 800-1600 MW galios elektrinę. Baltijos valstybiu sprendimas bendradarbiauti, statant naują elektrinę, visiškai atitiko globalias ir ES tendencijas plèsti atominę energetiką.

Projekto raidą pakeitė 2006 m. pabaigoje Baltijos valstybių ir Lenkijos ministru pirmininkų deklaracija dèl galimybẻs Lenkijai prisijungti prie atominès elektrinès Lietuvoje statybos ${ }^{81}$. Lenkijos įsitraukimą i projektą Baltijos valstybės pirmiausia siejo su galinčia pagreitèti elektros tilto statyba ${ }^{82}$, antra, sumažèsiančia finansine našta projekto dalyviams, trečia, galimybe statyti galingesnę elektrinę. Lenkijos vyriausybės norą prisijungti prie projekto galima paaiškinti, pirma, siekiu investuoti į elektros generavimo pajẻgumus Baltijos valstybėse, antra, galimybe igauti patirties atominės energetikos srityje, kurią vẻliau galès plèsti savo šalyje ${ }^{83}$, trečia, užsitikrinti, kad elektros tiltu į Lenkiją būtų tiekiama elektra, kuri pagaminta taip pat ir lenkų valdomoje elektrinejje, ketvirta, patenkinti Rytinių regionų paklausą elektros energijai ir daugiau Lenkijoje pagamintos elektros energijos eksportuoti į Vidurio ir Vakarų Europą.

Po Lenkijos deklaruotų ketinimų įsitraukti i projektą, buvo padidinta atominès elektrinès būsima galia iki 3200 MW. Tuo pačiu Lenkijos vyriausybès atstovai pateikè ultimatumą Lietuvai, kad sutiks investuoti i projektą tik su sąlyga, kad jiems atiteks ne mažiau trečdalio atominės elektrinès įmonès akcijų ir ne mažiau trečdalio elektrinès pagaminamos energijos (Lenkija norètų disponuoti 1200 MW galia) $)^{84}$. Tai Lenkijos įmonėms užtikrintų elektros tilto iš Lietuvos į Lenkiją apkrovą santykinai brangesne nei Rusijos elektros energija pagaminta naujoje atominejje elektrinejje ir priklausančia Lenkijos investuotojams. Trečdalio įmonės akcijų kontrolẻ leistų įmonės valdyme turèti tiek pat itakos, kiek ir Lietuvos nacionalinis investuotojas, o kitų Baltijos valstybių dalis turètų būti sumažinta iki 16 procentų. Atominės elektrinės statyba iš esmès būtų dvišalis Lenkijos ir Lietuvos projektas, kuriame dalyvautų ir Latvija bei

\footnotetext{
${ }^{80}$ Naujos atominés elektrines statybos Lietuvoje igyvendinamumo studijos rezultatu apibendrinimas, 2006 m. spalio 25 d., http:/ / www.lpc.lt/repository/Summary\%20Report\%20for\%20Media\%20-\%20LT. pdf, 20070813.

${ }^{81}$ Naujos atominés elektrinés statyba. Projekto chronologija, http://www.lpc.lt/lt/main/atom/ Events_nuclear, 20070901.

${ }^{82}$ Pakalkaite V., „Lenku bilietas į Ignaliną - ir elektros tiltas“, Verslo žinios, 2007 m. sausio 9 d., http://vz.lt/Default2.aspx?ArticleID=79a120d9-7ac6-4912-a499-c129d1ab9edf, 20070215.

${ }^{83}$ Lenkijos ministras pirmininkas Jaroslawas Kaczynskis apie siekius plètoti atominę energetiką Lenkijoje kalbëjo net savo inauguracinëje kalboje Parlamente 2006 m. liepos mėn. Žr., „World Nuclear Review - Week Ending 21st July 2006", The Nuclear Communication Network, No. 29/06, http://www.analys.se/lankar/Internat/NucNet/internatNucRew29_06.htm, 20070215.

${ }^{84}$ „Pokalbyje dèl naujos elektrinès - Lenkijos spaudimas“, Bernardinai.lt, 2007 m. liepos 21 d., http:/ / www.bernardinai.lt/index.php?url=articles/65476, 20070725.
} 
Estija. Tokia perspektyva, turint omenyje strateginès partnerystès su Lenkija patirti (pavyzdžiui, elektros tilto statybą), gali baigtis projekto žlugimu. Jei projekto dalyviai sutiks su Lenkijos reikalavimais, 3200 MW galios elektrinëje 1200 MW priklausys Lenkijos investuotojui, o Baltijos valstybėms liks 2000 MW. Atsižvelgiant ị tai, kad šis kiek yra panašus į planuotą pradžios projekte (1600 MW), Lenkijos dalyvavimo galima būtų ir atsisakyti. Tačiau tada iškiltu grèsmė elektros tilto statybai, o šis aspektas dar kartą patvirtina išvadą, kad Lenkija gali puikiai manipuliuoti Lietuvos poreikiais, užsitikrinant energetinį saugumą.

\section{Lietuvos ir Lenkijos santykiai naftos sektoriuje}

Naftos sektoriuje visa ES, ypač po plètros 2004 m., darosi panaši į tam tikrą perdirbimo zoną, jungiančią Rusiją su Šiaurès Amerika: trečdalis viso ES naftos importo tenka Rusijai, o ketvirtadalis naftos produktų eksporto $\mathrm{JAV}^{85}$. Lenkija ir Lietuva neatitinka šio ES šalių vidurkio. Lietuva importuoja naftą iš Rusijos, ją perdirba ir naftos produktus daugiausia eksportuoja i Vakaru Europą. Todèl Lietuvą pagrịstai galima laikyti naftos perdirbejja tarp Rusijos ir Vakaru Europos. Lenkija nepriklauso šalių naftos perdirbèju grupei, jungiančiai Rusiją ir Vakaru Europą, nes jos naftos perdirbimo pajègumų net neužtenka vidaus paklausai patenkinti. Kita vertus, tiek Lietuva (iki 2006 m. vidurio), tiek Lenkija priklauso Rusijos naftos transportuotojoms ì Vakarų Europą.

\subsection{Lietuvos ir Lenkijos naftos ūkis}

\subsubsection{Lietuvos ir Lenkijos naftos ūkio raidos tendencijos}

Lietuvoje naftos vartojimas pastaraji dešimtmetį buvo stabilesnis nei Lenkijoje, kur per pastaruosius dešimt metų naftos vartojimas išaugo 30 \% (žr. 6 paveikslą). Auganti vidaus paklausa neleidžia Lenkijai plèsti naftos produktu eksporto, Lenkija net yra priversta juos importuoti. Lietuvos stiprioji naftos ūkio pusè yra naftos perdirbimas ir naftos produktų eksportas (žr. 4 lentelę). $2006 \mathrm{~m}$. Lietuva importavo tik 2,5 karto mažiau naftos nei Lenkija, tačiau eksportavo 2 kartus daugiau naftos produktu.

\footnotetext{
${ }^{85}$ Kröppl C., "Oil Economy 2006“, Eurostat Data in Focus, 13/2007, http:/ / epp.eurostat.ec.europa. eu/cache/ITY_OFFPUB/KS-QA-07-013/EN/KS-QA-07-013-EN.PDF, 20070823.
} 


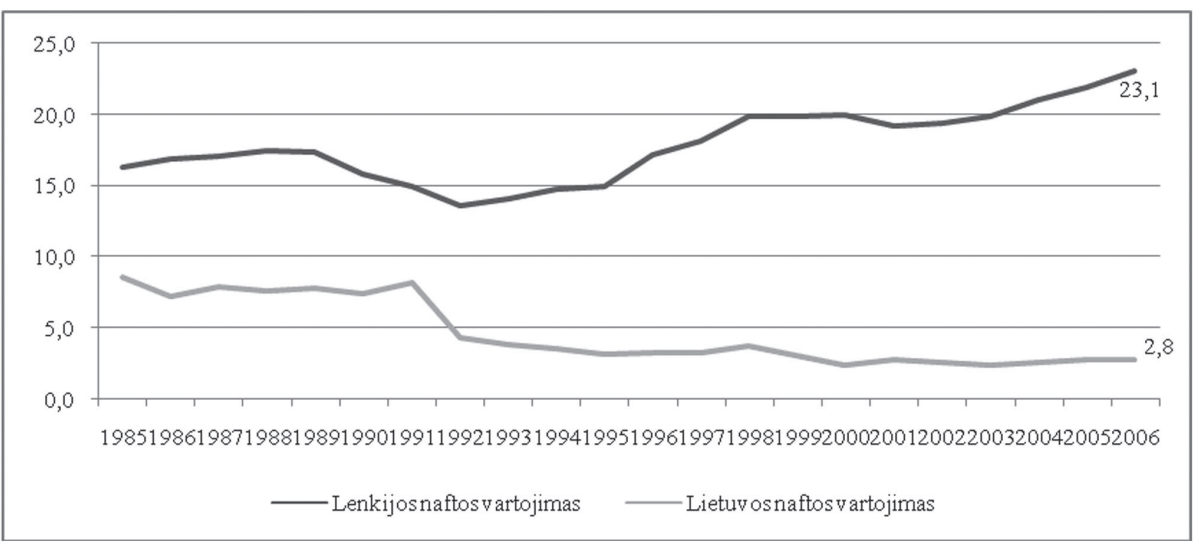

6 pav. Lenkijos ir Lietuvos naftos vartojimas ${ }^{86}$

Kita vertus, pastaraisiais metais naftos perdirbimo ir naftos produktu eksporto apimtys Lietuvoje mažejo. Pagrindinè naftos perdirbimo apimčiu pokyčių priežastis buvo ir yra Lietuvos naftos perdirbimo gamyklos „Mažeikiu nafta" savininkų santykiai su naftos tiekëjais - Rusijos naftos kompanijomis.

4 lentelè. Lietuvos ir Lenkijos naftos importo priklausomybè, tūkst. tonų ${ }^{87}$

\begin{tabular}{|c|c|c|c|c|}
\hline & & & Lietuva & Lenkija \\
\hline \multirow{16}{*}{ Žaliavos nafta } & \multirow{4}{*}{ Gavyba } & 2004 & 302 & 879 \\
\hline & & 2005 & 216 & 857 \\
\hline & & 2006 & 180 & 769 \\
\hline & & 2006/2005, proc. & $-16,7$ & $-10,3$ \\
\hline & \multirow{4}{*}{ Importas } & 2004 & 8756 & 17930 \\
\hline & & 2005 & 9000 & 18281 \\
\hline & & 2006 & 8518 & 20680 \\
\hline & & 2006/2005, proc. & $-5,4$ & 13,1 \\
\hline & \multirow{4}{*}{ Eksportas } & 2004 & 193 & 178 \\
\hline & & 2005 & 147 & 237 \\
\hline & & 2006 & 116 & 283 \\
\hline & & 2006/2005, proc. & $-21,1$ & 19,4 \\
\hline & \multirow{4}{*}{ Perdirbimas } & 2004 & 8682 & 18867 \\
\hline & & 2005 & 9227 & 18822 \\
\hline & & 2006 & 8251 & 21548 \\
\hline & & 2006/2005, proc. & $-10,6$ & 14,5 \\
\hline
\end{tabular}

\footnotetext{
${ }^{86}$ The BP Statistical Review of World Energy 2007.

${ }^{87} \mathrm{Kröppl}$.
} 


\begin{tabular}{|c|c|c|c|c|}
\hline \multirow{12}{*}{ Naftos produktai } & \multirow{4}{*}{ Vartojimas } & 2004 & 1907 & 19574 \\
\hline & & 2005 & 2022 & 19803 \\
\hline & & 2006 & 2059 & 21268 \\
\hline & & 2006/2005, proc. & 1,8 & 7,4 \\
\hline & \multirow{4}{*}{ Importas } & 2004 & 441 & 5025 \\
\hline & & 2005 & 421 & 5527 \\
\hline & & 2006 & 498 & 5783 \\
\hline & & 2006/2005, proc. & 18,3 & 4,6 \\
\hline & \multirow{4}{*}{ Eksportas } & 2004 & 6558 & 2334 \\
\hline & & 2005 & 6697 & 2496 \\
\hline & & 2006 & 6245 & 2851 \\
\hline & & 2006/2005, proc. & $-6,7$ & 14,2 \\
\hline
\end{tabular}

Lenkijos ir Lietuvos naftos vartojimo prognozių palyginimas (žr. 7 paveikslą) rodo, kad, pirma, Lietuvoje ir Lenkijoje naftos vartojimas augs apie $2 \%$ kasmet. Antra, naftos gavyba Lietuvoje augs taip pat apie $2 \%$ kasmet, o Lenkijoje - pasiekusi piką $2015 \mathrm{~m}$. pradės mažèti. Tačiau abejose šalyse naftos gavyba išliks minimali - nesieks $1 \mathrm{mln}$. tonu per metus. Trečia, smarkiai didès naftos importas. Lenkijai $2020 \mathrm{~m}$. reikès $6 \mathrm{mln}$. tonų daugiau nei $2005 \mathrm{~m}$., Lietuvai $-2 \mathrm{mln}$. tonų daugiau. Ketvirta, Lietuvos naftos importo augimas bus daugiausia susijęs su naftos perdirbimu ir naftos produktų eksportu. Lenkija ateityje vis daugiau importuos tiek naftos, tiek naftos produktu. $2020 \mathrm{~m}$. Lietuva, jei visą naftos produktų eksportą nukreiptų į Lenkiją, galètų beveik patenkinti Lenkijos paklausą naftos produktų importui.

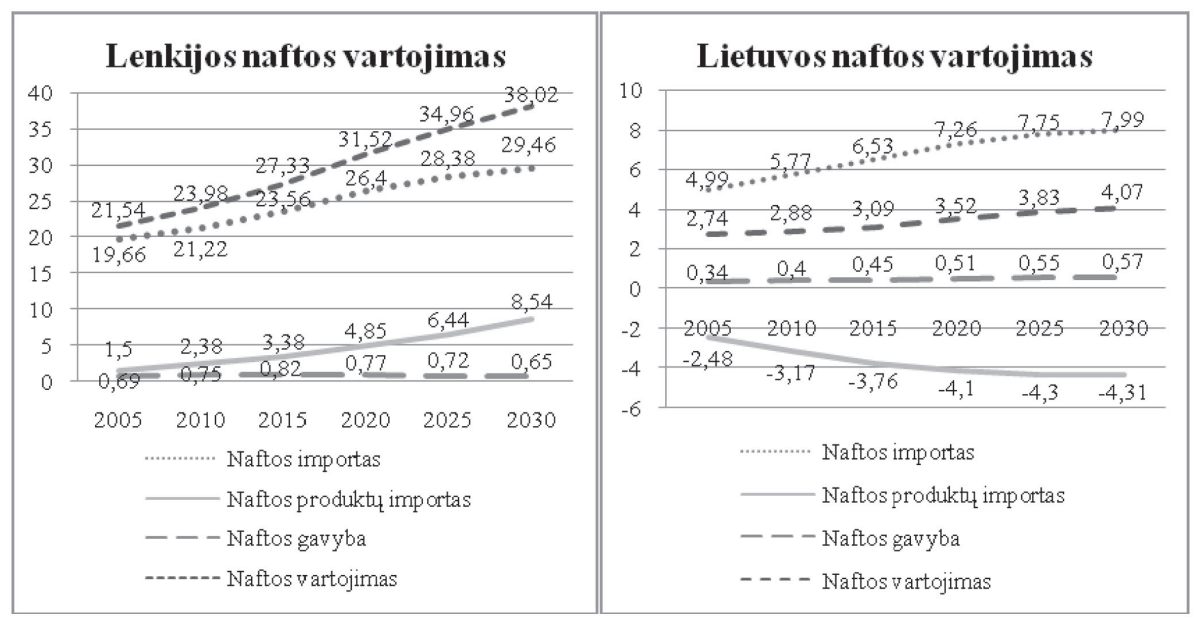

7 pav. Lietuvos ir Lenkijos naftos vartojimas, $\mathrm{mln} . \mathrm{t}^{88}$

$\overline{{ }^{88} \text { European Energy and Transport - Trends } 2030 .}$ 
Abiejų šalių naftos importo struktūra yra panaši (žr. 8 paveikslą): Lietuva iš Rusijos 2006 m. importavo 97 \% naftos, Lenkija - 92 \%. Atsižvelgiant į tai, kad Rusijos naftos eksportas 2006 m. smuko $1 \%$ ir sudarè 249,91 mln. tonu ${ }^{89}$, eksportas į Lietuvą ir Lenkiją sudarè 10,36 \% iš viso eksporto (Lenkija - 9,24 \%). Šios apimtys rodo vienpusę Lietuvos ir Lenkijos priklausomybę nuo Rusijos. Kita vertus, prekyba nafta dèl įvairesnių transportavimo būdų (vamzdynais, geležinkeliais, tanklaiviais) yra lankstesnè nei prekyba gamtinėmis dujomis, todèl šie kiekiai gali kisti ir kinta.

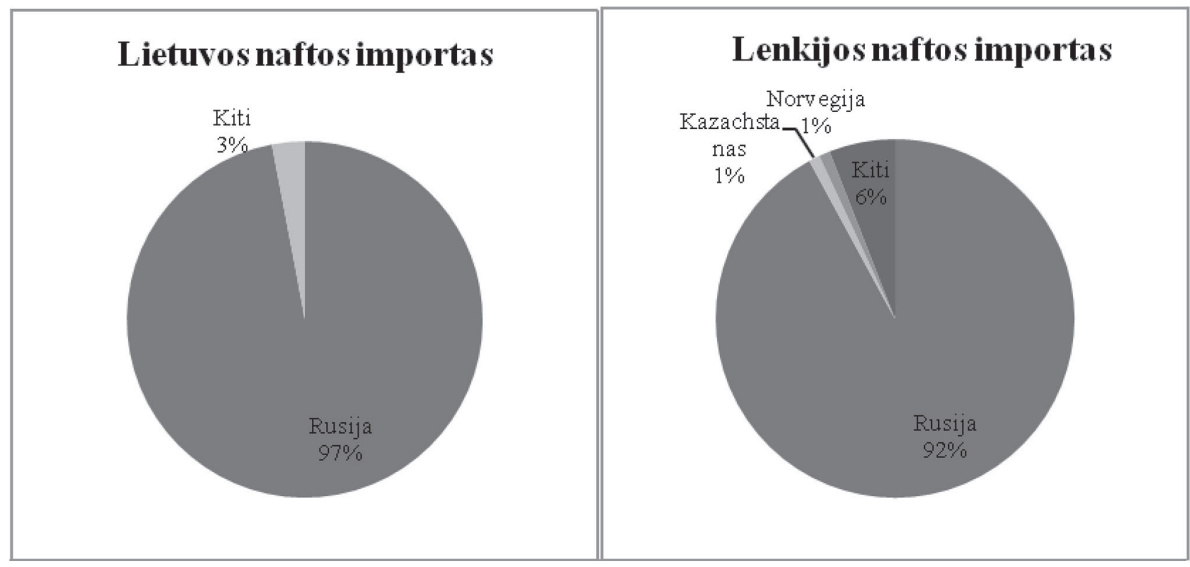

8 pav. Lietuvos ir Lenkijos naftos importas ${ }^{90}$

Lietuva naftos perdirbimo srityje iki paskutinio „Mažeikių nafta“ savininku pasikeitimo buvo Lenkijos konkurentè tik trumpuoju laikotarpiu - vidutiniu laikotarpiu Lietuva galejo tapti svarbia naftos produktų tiekèja Lenkijai. Tai būtų Lenkijai leidę diversifikuoti naftos produktų importą. Žinoma, tokia diversifikacija būtų efektyvi tik tuo atveju, jei „Mažeikių nafta“ nepriklausytu Rusijos kompanijoms.

\subsubsection{Naftos tranzitas per Lietuvą ir Lenkiją}

Naftos tranzito versle Lietuva ir Lenkija iki 2006 m. vidurio buvo konkurentès. Per Lenkijos teritoriją kasmet naftotiekiu „Družba“ (žr. 9 žemèlapi) transportuojama apie 20-22 mln. tonų naftos į Vokietiją ${ }^{91}$ - šiek tiek daugiau

\footnotetext{
89 "Russian Oil Exports Down 1\%, Gas Exports 3\% in 2006-Ministry“ , RIA Novosti, 2007 m. vasario 1d., http:/ /en.rian.ru/russia/20070201/60026020.html, 20070205.

${ }^{90}$ Kröppl.

${ }^{91}$ AFP, Russian Oil Supplies to Poland, Germany Caught in Belarus Dispute, 2007 m. sausio 8 d., http:/ / www.breitbart.com/article.php?id=070108124819.kkhgowaq\&show_article=1, 20070205.
} 
nei Lenkija pati suvartoja (žr. 6 paveikslą). Taip pat per Gdansko uostą yra eksportuojama apie $10 \mathrm{mln}$. tonų naftos per metus ${ }^{92}$.

Lietuva iki avarijos „Družba“ naftotiekio atšakoje (žr. 9 žemèlapi) per Būtingès naftos terminalą eksportuodavo apie 6-7 mln. tonų Rusijos žaliavinès naftos (2004 m. - 7,1 mln. t, 2005 - 6,2 mln. t, iki 2006 m. vidurio - 2,8 mln. t) ${ }^{93}$ apie 2 kartus daugiau nei vidaus vartojimas ${ }^{94} .2006$ m. liepos 29 d. „Družba“ naftotiekio atšakoje į Lietuvą (naftotiekio Uneča-Primorskas pirmojoje linijoje) Rusijos Federacijos Briansko srityje įvyko naftotiekio avarija - iš vamzdyno išsiliejo 48 kubiniai metrai naftos (apie 40 tonų). Vamzdyne buvo sumažintas spaudimas ir Lietuva liko be naftos ${ }^{95}$.

Po avarijos Rusijos Federalinė ekologinès, technologinès ir atominės priežiūros tarnyba (toliau - „Rostechnadzor") atliko vamzdyno techninès būklès patikrinimą ir rado 7853 naftotiekio pažeidimus, kuriuos būtina likviduoti prieš pradedant vèl eksploatuoti vamzdyną. 2007 m. rugsëjo mèn. „Rostechnadzor" patvirtino, kad yra pasirengę atlikti visus remonto darbus su sąlyga, kad juos finansuos "Transneft"

\footnotetext{
${ }_{92}$ Baltic Maritime Outlook 2006. Goods Flows and Maritime Infrastructure in the Baltic Sea Region, March 2006, http://ec.europa.eu/transport/intermodality/motorways_sea/doc/potential/2006_03_baltic_maritime_outlook.pdf, 20070205.

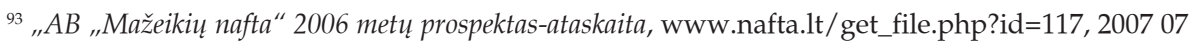
05.

94 "Mažeikių nafta“ priklauso: Būtingės naftos terminalas (pajègumas $-14,1 \mathrm{mln}$. t per metus), naftos perdirbimo gamykla, $83 \mathrm{~km}$ atkarpa naftotiekio Polockas - Ventspilis (pajègumas - 14,3 mln. t per metus), $225 \mathrm{~km}$ atkarpa naftotiekio Polockas - „Mažeikių nafta“ perdirbimo gamykla (pajėgumas 16,4 mln. t per metus), 91 km dvipusis naftotiekis „Mažeikių nafta“ - Būtingès naftos terminalas (eksporto pajègumai - 14,1 mln. t, importo - 10,8 mln. t per metus), $87 \mathrm{~km}$ produktotiekis Biržai Alūkstos (pajëgumas $7,8 \mathrm{mln}$. $\mathrm{t}$ per metus).

${ }^{95}$ Tokio pobūdžio nedideli (iki 100 tonu) naftos išsiliejimai nėra išskirtinis įvykis $30-40$ metu senumo vamzdyne (pirmoji vamzdyno linija buvo pastatyta 1968 m., antroji - 1974 m.). Kaip teigiama Jungtinès Jungtinių Tautu vystymo programos ir Pasaulio banko paramos energetikos sektoriaus valdymui programos $2003 \mathrm{~m}$. atliktoje studijoje Russia Pipeline Oil Spill Study nustatyta aiški koreliacija tarp vamzdynų amžiaus ir avariju - daugiau nei 30 \% visų naftos išsiliejimu ịvyksta senesniuose nei 20 metų naftotiekiuose. Žr. Joint UNDP / World Bank Energy Sector Management Assistance Programme, Russia Pipeline Oil Spill Study, April 2003, http:/ /www.esmap.org/filez/ pubs/03403RussiaPipelineOilSpillStudyReport.pdf, 20070205.
}

${ }^{96}$ Newsru, „Дружбе“ конец: трубопровод в Литву не будет отремонтирован, 2007 m. rugsèjo 7 d., http://www.newsru.com/finance/07sep2007/druzhba.html, 20070907. 


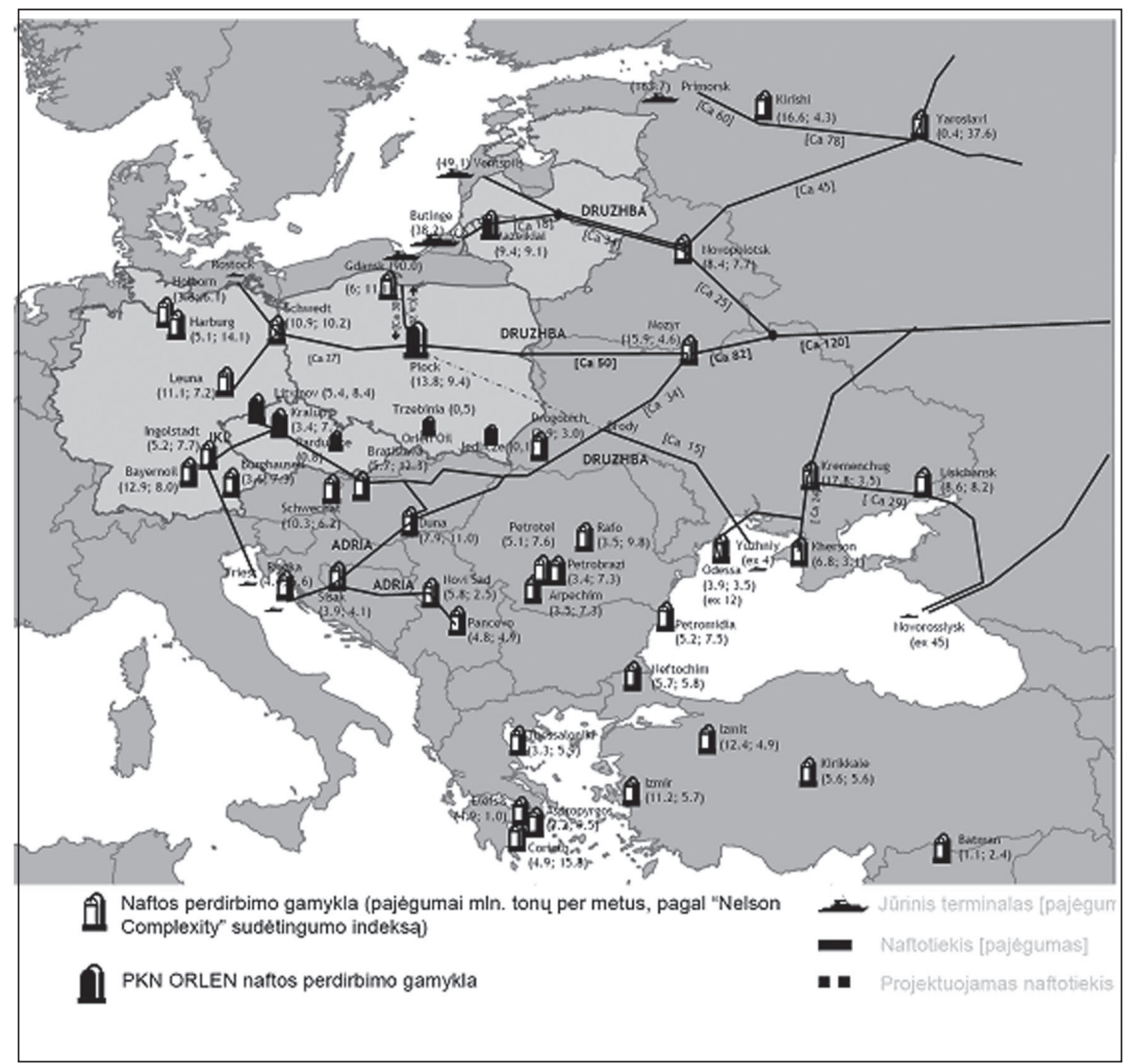

\section{9 žemèlapis. Vidurio ir Rytų Europos naftos pramonès infrastruktūra97}

Šis sprendimas leidžia daryti prielaidą, kad naftotiekis nebus remontuojamas, o Lietuva nebebus naftos tranzito šalimi. Pirma, Rusija vadovaujasi principu „Rusijos kroviniai į Rusijos uostus“ - naftos eksportas didinamas per Rusijos terminalus, kurių pajėgumai yra nuolat plečiami. $7 \mathrm{mln}$. tonų naftos, kurie būdavo eksportuojami per Lietuvą, nėra didelis kiekis Rusijai. Antra, Rusija siekia kuo daugiau naftos perdirbti savo teritorijoje ir eksportuoti daugiau naftos produktų. Trečia, Rusija siekia diversifikuoti naftos eksportą Rytu kryptimi. Todèl, ypač po to, kai Būtingès naftos terminalo kontrolè perëjo ne Rusijos, o Lenkijos kompanijai, tiek dèl politiniu, tiek dèl ekonominių priežasčiu Rusijai nėra prasmès renovuoti naftotiekį i Lietuvą ir atnaujinti naftos tiekimą. Galima teigti, kad naftos tranzito per Lietuva praradimas buvo dalis Lietuvos kainos sumokètos už įmonės pardavimą „PKN Orlen“.

\footnotetext{
${ }^{97}$ Chalupec I., "Mažeikiu naftos" isigijimas - stiprios regioninès grupés Centrinëje Europoje formavimas, 2006 m. gruodžio 15 d., http:/ / www2.orlen.pl/pub/files/MN_Closing_IR_v15122006_LT.pdf, 20070705 .
} 
Atsižvelgiant į naftotiekio „Družba“ amžių, Rusija ateityje vis dažniau susidurs su dilema remontuoti senstantį naftotiekį ar statyti naujus. Akivaizdu, kad atsakymas dažnai priklausys ne tik nuo ekonominiu, bet ir nuo geoenergetiniu argumentu - Rusijos, kaip tiekejjos, santykių su tranzito ir vartojimo valstybėmis. Dẻl šios priežasties galima prognozuoti, kad Rusijos naftos tranzito valstybiu kiekis ateityje mažès ir ne tik Lietuva, bet ir Lenkija gali likti tik Rusijos naftos vartotoja. Remdamasi naftotiekio techninės būklès argumentu, Rusija 2003 m. nutraukè naftos tranzitą per Latviją (tai leido padaryti naftos eksporto per Būtingès naftos terminalą galimybè), o 2006 m., padidëjus Primorsko naftos terminalo pajėgumams, per Lietuvą. Jei/kai atsiras galimybė nukreipti šiaurinès naftotiekio „Družba“ linijos (Baltarusija-Lenkija-Vokietija) kieki kita kryptimi, Baltarusija ir Lenkija gali likti ne tik be naftos tranzito pajamu, bet ir bus priverstos ieškoti galimybių importuoti naftą iš alternatyviu šaltinių: Rusijos kompanijoms gali pasirodyti pelningiau naftą parduoti Vakaru Europos ar Azijos šalims, o ne kaimynems. Taip pat atsiras galimybè vykdyti dar aktyvesnę „skaldyk ir valdyk" politiką - Rusijos kompanijos galès rinktis tarp „patrauklesnių“ partneriu prekybai Vidurio Europoje. Ženklu, kad Lenkija nebebus naftos tranzito valstybė jau yra - nuo 2007 m. antrojo ketvirčio „Transneft" nutraukė Rusijos naftos eksportą per Gdansko naftos terminalą ${ }^{98}$.

\section{2. „PKN Orlen“ investicijų Lietuvoje pasekmès Lietuvos energetiniam saugumui}

\subsection{1. „PKN Orlen“ investicijų Lietuvoje priežastys}

Naftos tranzito funkcijos praradimas sumažino Lietuvos ir Lenkijos geoenergetinių santykių naftos ūkyje intensyvumą (to paties tiekejjo išteklių transportavimas). Kita vertus, „PKN Orlen“ įsigijus „Mažeikių naftą" (toliau $\mathrm{MN}$ ) ir Būtingès naftos terminalą ${ }^{99}$, abiejų šalių naftos sektoriai tapo neišvengiamai susiję. Lietuvos naftos perdirbimo ūkio perspektyvos nuo šiol priklausys ne tik nuo „PKN Orlen“ gebejjimų aprūpinti naftos perdirbimo gamyklą nafta, bet ir nuo „PKN Orlen“ tarptautiniu poziciju - gebejjimo konkuruoti Vidurio ir Rytų Europoje su Vengrijos MOL ir Austrijos OMV.

Kaip teigia „PKN Orlen", tai didžiausias pirkimo sandoris Lenkijos istorijoje $\mathrm{e}^{100}$. Tačiau ir energetinio saugumo požiūriu MN pirkimas buvo svarbesnis Lenkijai nei Lietuvai jos pardavimas „PKN Orlen“. Lenkijos kompanijos

\footnotetext{
${ }^{98}$ Zhdannikov D., „,Russia sets flat Q2 oil export schedule“, Reuters, 2007 m. kovo 21 d., http:/ / uk.reuters.com/article/oilRpt/idUKL213035720070321, 20070515.

${ }^{99} 2006$ m. gruodžio mèn. „PKN Orlen“ iš „,Yukos International UK B.V.“ už 1,492 mlrd. JAV doleriu įsigijo 53,7 proc., o už 0,851 mlrd. JAV dolerių iš Lietuvos Vyriausybės $-30,66$ proc. MN akcijų. Visas $84,36 \%$ akciju paketas Lenkijos kompanijai kainavo 2,34 mlrd. JAV doleriu (likusias akcijas valdo: Lietuvos Vyriausybe் - $10 \%$, smulkieji akcininkai - 5,64 procento).

${ }^{100}$ Chalupec.
} 
motyvus pirkti MN ir pasiūlyti didžiausią kainą Rusijos teisėsaugos persekiojamiems „Yukos International UK B.V.“ savininkams lèmé, kaip teigia „PKN Orlen" vadovai ${ }^{101}$, pirma, natūrali kompanijos plètra, ieškant perspektyviu įsigijimų ir orientavimasis ị rinką, turinčią didelio augimo potencialą. Antra, MN gamykloje nafta perdirbama aukštu sudètingumo lygiu, tai yra vienintelis naftos perdirbẻjas Baltijos šalyse. Trečia, MN valdo Lietuvos žaliavos naftos ir naftos produktų vamzdynų sistemą, taip pat jai priklauso Būtingès naftos ir naftos produktų eksporto-importo terminalas. Ketvirta, MN naftos produktu eksporto rinkos apima Baltijos valstybes, Vakarų Europą ir JAV. Šalia oficialių tikslų galima nurodyti ir dar kelis - „PKN Orlen“ poziciju sutvirtinimas Lenkijoje ir Lenkijos rinkos apsauga nuo Rusijos kompanijų plètros ${ }^{102}$.

MN kontrolè yra vartai ne tik į Baltijos valstybių naftos produktų rinką, bet ir į Lenkijos (ypač atsižvelgiant i išaugsiančią naftos produktų paklausą Lenkijoje). Jei MN būtų atitekusi naftos kompanijai, išgaunančiai naftą, pagrindinė „Mažeikių nafta" produkcijos plètros rinka būtų Lenkija. Naftą išgaunanti kompanija galètų sumažinti naftos perdirbimo kaštus (dẻl mažesnès žaliavos kainos) ir sèkmingai konkuruoti su naftos neišgaunančiomis kompanijomis - pirmiausia „PKN Orlen“. Jei naftą išgaunanti kompanija būtų iš Rusijos, grèsmè „PKN Orlen" būtų dar didesnè (nei, pavyzdžiui, MN įsigijus Kazachstano „Kazmunaigaz"), nes Lenkija (ne tik rinka, bet ir naftos perdirbimo bendrovès) visada buvo Rusijos kompanijų taikinys. Kai kurie Lenkijos naftininkai manė, kad „PKN Orlen“ negalètų atlaikyti pigių naftos produktų konkurencijos ir kompanija būtų subankrutavusi, o tada ir ją perimtų Rusijos įmonès ${ }^{103}$. Dèl šios priežasties MN pirkimas tiek „PKN Orlen“, tiek Lenkijos vyriausybei turëjo būti vienas svarbesnių energetinio saugumo užtikrinimo uždavinių. Lietuvai MN pardavimas energetinio saugumo požiūriu turèjo remtis pagrindine sąlyga, kad MN neatitektų tiekëjui - Rusijos kompanijoms, kurios būtų pajėgios monopolizuoti rinką ir išplèsti savo įtaką visame Lietuvos energetikos sektoriuje.

\subsubsection{Energetinio saugumo iššūkiai Lietuvos naftos sektoriui}

Padètis Lietuvos naftos ūkyje yra saugiausia visame energetikos sektoriuje (net praradus naftos tranzito funkciją ir likus tik perdirbëja). Siekdama užtikrinti stabilų jo veikimą, Lietuva turètų būti suinteresuota MN savininku stabilumu, kad nebūtų sudarytos sąlygos Rusijos kompanijoms dar kartą pretenduoti sustiprinti savo įtaką Lietuvoje. Taip pat reikia plèsti nepriklausomo apsirūpinimo naftos produktais pajègumus. Lietuva naftos produktais gali

\footnotetext{
${ }^{101}$ Chalupec.

${ }^{102}$ Plačiau apie „PKN Orlen“ motyvus pirkti „Mažeikių naftą“ žr. BRE Bank Securities, PKN Orlen. Expansion to Lithuania, 2006 June 5, http:/ /i.wp.pl/a/dibre/aspolek/pkn_050606_eng.pdf, 2007 0705 .

${ }^{103}$ Komaras J. J., „Kodèl lenkai bijo rusų Mažeikiuose?“, Lrytas.lt, 2006 m. balandžio 9 d., http:/ / www.lrytas.lt/?id=11445789341142311187\&view=4, 20070825.
} 
apsirūpinti arba iš MN, arba juos importuodama. Jei MN dèl vienų ar kitų priežasčių nutrauktų veiklą, diversifikuotas ir lankstus importas leistų išlaikyti stabilumą naftos produktų tiekime.

Neutralizavusi grèsmes iš Šiaurès Rytų, „PKN Orlen“ gali saugiau plèsti įtaką Vidurio Europoje, kurioje veikia du pagrindiniai kompanijos konkurentaiVengrijos MOL ir Austrijos OMV (žr. 9 paveikslą). Nuo sėkmingos „PKN Orlen“ konkurencinės kovos priklausys ir MN plètros galimybės (Lenkijos kompanijos investiciniai pajègumai). Kita vertus, energetinio saugumo požiūriu, Lietuvai svarbiausia yra tai, kad nepasikeistų MN savininkai ir vẻl nekiltų Rusijos kompaniju dominavimo grèsmè, t. y., kad bent vidutiniu laikotarpiu „PKN Orlen“ nebūtų priversta gamyklos parduoti. Sèkminga Lenkijos kompanijos verslo plètra Lietuvai turètų rūpèti tik tiek, kiek „PKN Orlen“ bus pajègi igyvendinti investicinius įsipareigojimus. Žinoma, ši motyvacija pasikeistų, jei Lietuvos Vyriausybè nuspręstų tapti dalies „PKN Orlen“ akcijų savininke, tačiau toks žingsnis yra mažai tikètinas dèl abejotino investicinio tikslingumo.

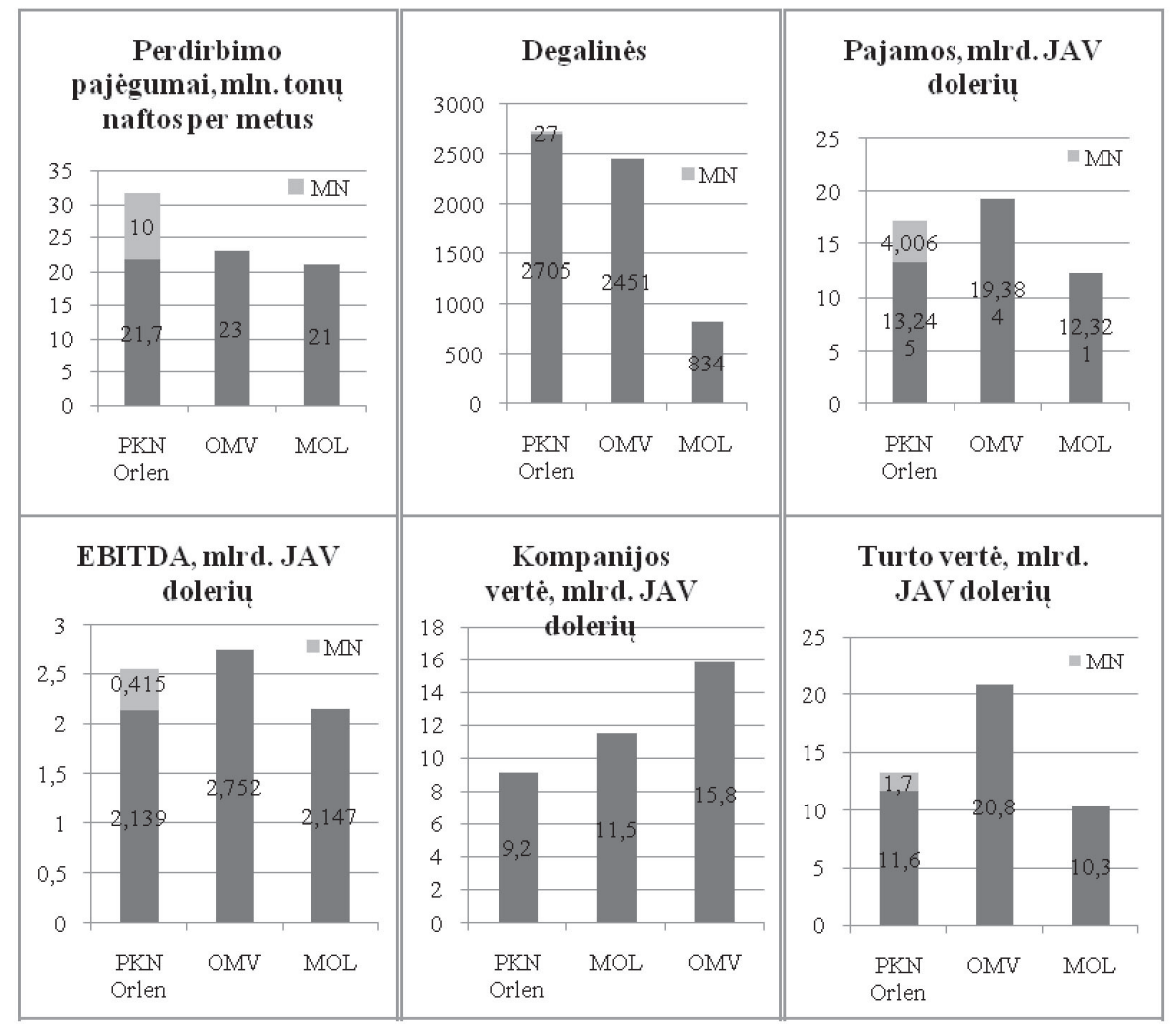

9 pav. „PKN Orlen“, OMV ir MOL veiklos palyginimas, 2005 m. ${ }^{104}$

${ }^{104}$ Chalupec. 
„PKN Orlen“ plètra galima trimis kryptimis, pirma, stiprinant pozicijas Lenkijoje, antra, didinant įsigijimus Vidurio ir Rytų Europoje, trečia, susijungiant su kita Vidurio ir Rytų Europos kompanija. Pozicijų Lenkijoje stiprinimas siejamas su susijungimu su valstybès kontroliuojama (51,9\% akcijų) „Lotos Group" , kuri valdo Gdansko naftos perdirbimo gamyklą ir 400 degalinių tinklą. Tokią kompaniju perspektyvą remia „PKN Orlen“" vadovybe் ${ }^{105}$. Susijungusiu kompanijų kapitalizacija siektų 13 mlrd. JAV dolerių ${ }^{106}$ ir tai būtų daugiau už MOL vertę (žr. 9 paveikslą). Antroji kryptis - didinti naftos perdirbimo ir prekybos naftos produktais kompaniju įsigijimą Europoje, kurių lieka vis mažiau. Trečioji kryptis - susijungimas su kita naftos kompanija. Apie galimą „PKN Orlen“ susijungimą su Vengrijos MOL nuolat svarste tiek kompanijų vadovai, tiek Lenkijos ir Vengrijos Vyriausybès. Susijungus kompanijoms, naujo koncerno kapitalas siektų daugiau nei 20 mlrd. JAV doleriu, kompanija turètu degalinių Lenkijoje, Vengrijoje, Čekijoje, Slovakijoje, Vokietijoje ir Lietuvoje. Tokia kompanija galètų atlaikyti išorès spaudimą - ne tik iš OMV, bet ir iš Rusijos įmonių pusès. Tai taip pat leistų susitelkti dar didesnei Vidurio ir Rytų Europos naftos perdirbimo erdvei. Lietuvai „PKN Orlen“ galimas susijungimas su MOL, taip pat MN priklausymas didesniam koncernui tiesiogiai svarbūs tiek, kiek tai sustiprins įsipareigojimus išlaikyti MN nuosavybę, plèsti naftos perdirbimo ūkį Lietuvoje ir aprūpinti Lietuvos rinką naftos produktais.

Lietuva apsirūpinti naftos produktais gali arba gaudama juos iš $\mathrm{MN}$, arba importuodama. Importuoti Lietuva taip pat gali arba geležinkeliu, arba per „Klaipėdos nafta" terminala.. Atsižvelgiant į tai, kad jūros importas yra lankstesnis ir leidžia labiau diversifikuoti tiekëjus, Lietuvai yra ypač svarbu išlaikyti jo kontrolę. Kaip teigiama Nacionalinëje energetikos strategijoje, Lietuva diversifikavo naftos produktų tiekimo galimybes ir „,techniškai yra apsaugota nuo galimų tiekimo iš kurios nors vienos šalies sutrikimų. Naftos produktu poreikiams tenkinti Lietuva turi pakankamai transportavimo, perdirbimo, saugojimo ir paskirstymo pajėgumų “107.

„Klaipėdos nafta“ kontrolinis akciju paketas (70,6 \%) priklauso Lietuvos Vyriausybei, kompanija valdo reversinį (galintį tiek eksportuoti, tiek importuoti) naftos produktu terminalą, kurio pajëgumas viršija Lietuvos rinkos poreiki ir siekia 7,1 mln. tonu per metus. $2006 \mathrm{~m}$. terminalas perpylè 5,5 mln. tonų naftos produktu, pagrindinis „Klaipėdos nafta“ klientas yra „Mažeikių nafta“ (76 \% visos naftos produktų krovos) ${ }^{108}$. Dèl šios priežasties „Klaipėdos nafta“ veikla šiuo metu priklauso nuo „Mažeikių nafta“" perdirbimo apimčių ir šios produkcijos eksporto. Kita vertus, terminalas potencialiai galètų tapti naftos produktų importo vartais, jei „Mažeikių nafta“ veikla pradètų strigti. Taip pat „Klaipėdos nafta“ terminalas gali būti naudojamas ir naftos importui į tą pačią „Mažeikių nafta“. Dèl šio daugiafunkciškumo terminalo valstybinè kontrolè leidžia išlaikyti balansą ir stabilumą

\footnotetext{
${ }^{105}$ Interfax, Polish PKN Orlen plans to merge with Lotos, no Warsaw listing for Czech Unipetrol, 2007 September 4, http:/ / www.interfax.com/5/309376/news.aspx, 20070905.

106 „PKN Orlen ambicijos“, Versus, 2007 m. gegužès 7 d., http://www.lrytas.lt/ ?id=11785581771176340376\&view=4\&p=4, 20070905.

${ }^{107}$ Nutarimas dél Nacionalinés energetikos strategijos patvirtinimo.

${ }^{108}$ AB "Klaipédos nafta“, Metinis pranešimas 2006 m., 2007 m. kovas, http://www.oil.lt/uploads/ media/Metinis_pranesimas_2006_patvirtintas.pdf, 20070705.
} 
Lietuvos naftos produktų rinkoje. Terminalo savininkų pasikeitimas apribotų ši lankstumą: jei „Klaipedos naftą“ valdytų Rusijos kompanijos, jos priklausomai nuo situacijos ir santykių su „PKN Orlen" būtų suinteresuotos arba naftos produktų eksportu per Lietuvą (mažindamos MN eksporto galimybes), arba importu i Lietuvą ir konkurencija su MN produkcija. Jei terminalą valdytų MN savininkas, jis turètų visišką naftos sektoriaus kontrolę (importas, perdirbimas, eksportas). Atsižvelgiant į tai, kad „PKN Orlen“ ketina kontroliuoti nuo 30 iki 50 \% Baltijos valstybių mažmeninès prekybos degalais rinkos, kompanijos intencijos nusipirkti ir „Klaipėdos nafta" terminalą ${ }^{109}$ turètų būti vertinamos atsargiai. Imonès kontrolès praradimo pasekmė Lietuvai būtų taikstymasis su dominuojančia naftos sektoriuje kompanija ir jau minèto lankstumo praradimas.

\subsubsection{Lenkijos ir Lietuvos energetiniam saugumui įtaką turintys naftotiekių projektai}

Siekdama išlaikyti naftos perdirbimo kieki, „PKN Orlen“ savo perdirbimo gamykloms per metus turès pirkti $30 \mathrm{mln}$. tonų naftos. Jei visa ši nafta būtų perkama iš Rusijos kompaniju, tai sudarytų 12 \% iš viso Rusijos naftos eksporto. Tai yra pakankamai didelis kiekis turèti tvirtas derybines pozicijas. Kita vertus, „PKN Orlen“ pozicijos yra silpnos, nes kompanijos naftos tiekimo sistema perdirbimo gamykloms priklauso nuo Rusijos (žr. 10 žemẻlapi). Atsižvelgiant i tai, kad Rusija vis labiau diversifikuoja eksporto kryptis, „PKN Orlen“ gali kilti problemų apsirūpinant nafta. Tačiau šios problemos yra labiau tikètinos importo jūra galimybės neturinčioms naftos perdirbimo gamykloms nei MN.

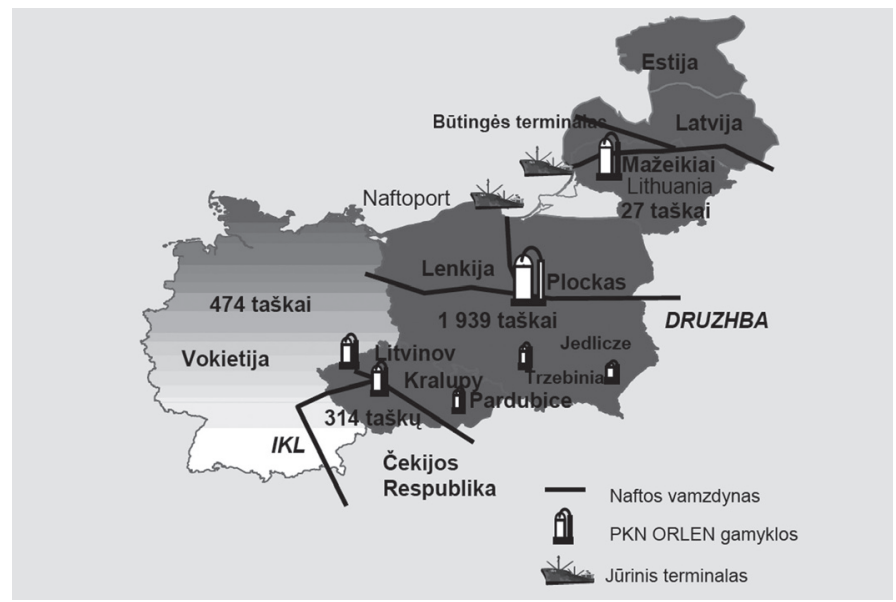

10 žemèlapis. „PKN Orlen“ valdoma infrastruktūra110

109 „PKN Orlen“ taikinys - „Klaipėdos nafta“, Balsas.lt, 2007 m. kovo 28 d., http:/ / balsas.lt/naujienos/verslas/straipsnis68637, 20070822.

${ }^{110}$ Chalupec. 
„PKN Orlen" valdomos įmonès ir visos Vidurio Europos valstybės gali susidurti su naftos tiekimo problema, jei Rusija igyvendins ketinimus aplenkti nereikalingus tarpininkus - „Družba“ naftotiekio tranzito valstybes. Sunkiai tikètina, kad naftos tiekimas bus iš viso nutrauktas, tačiau gali sumažèti tranzito apimtys ir pakisti naftos tiekimo vidaus poreikiams sąlygos. Kaip tik toks projektas yra Rusijos „Baltijos vamzdynų sistemos-2“ su naftos terminalu Primorske plètra, nutiesiant naftotiekį Uneča-Primorskas (žr. 9 žemėlapi). Po 2007 m. pradžioje ivykusio konflikto tarp Baltarusijos ir Rusijos dèl naftos kainos, muitų už eksportuojamą naftą pasidalijimo ir naftos tranzito per Baltarusijos teritoriją mokesčiu, Rusijos naftotiekių monopolininkas „Transneft" pristatè programą prieš krizę. Vienas jos punktų yra „Baltijos vamzdynų sistema-2“ naftotiekio „Uneča-Primorskas" statyba ${ }^{111}$. $1157 \mathrm{~km}$ ilgio naftotiekis kainuos 2,5 mlrd. JAV dolerių ${ }^{112}$. Už šią sumą Rusija nusipirks galimybes: pirma, niekada neatnaujinti naftos tranzito per Lietuvą (nebent MN savininkais taptų „draugiškesnès“ kompanijos), antra, visiškai nutraukti naftos eksportą naftotiekio „Družba“ atšaką per Lenkija, trečia, manipuliuoti naftos eksporto apimtimi tarp visų naftotiekio "Družba“ atšakų ir tranzito valstybiu, ketvirta, didinti eksportuojamos naftos kainą. Lenkijai naujasis naftotiekis bus milžiniškas iššūkis, nes gali tekti naftą importuoti per šiuo metu eksportui skirtą terminalą (kaip atsitiko Būtingès naftos terminalui), o tai padidintų importuojamos naftos kainą ir mažintu „,PKN Orlen“ "konkurencingumą. Lietuvos situacijos, skirtingai nei Lenkijos, naujasis vamzdynas iš esmės nekeičia.

Alternatyva pristatytai neoptimistinei perspektyvai yra Lenkijos planai diversifikuoti naftos importą vamzdynais, pirmiausia pritraukiant Kaspijos jūros baseino naftą. Toks uždavinys yra iškeltas Odesa-Brodai-Plockas naftotiekio projekte. Odesa-Brodai naftotiekio ${ }^{113}$ tolimesnė plètra iki Lenkijos Plocko naftos perdirbimo gamyklos (o iš ten į Gdansko naftos terminalą) būtų leidusi ne tik Ukrainai, bet ir Lenkijai diversifikuoti importą ir tapti svarbia naftos tiekimo

\footnotetext{
${ }^{111}$ Newsru, Россия может быстро построить трубу в обход Белоруссии и отказаться от поставок нефти в Литву, 2007 m. vasario 13 d., www.newsru.com/finance/13feb2007/vainshtock.html, 200706 10. Naftotiekio pajėgumas pirmajame etape turètų siekti $50 \mathrm{mln}$. tonų naftos per metus, taip pat būtų didinamas Primorsko naftos terminalo pajègumas iki $130 \mathrm{mln}$. tonų per metus. Pramonès ir energetikos ministerijai ir „Transneft“ Rusijos Federacijos vyriausybė 2007 m. pirmoje pusèje pavedẻ per 18 mẻn. (iki 2009 m. pradžios) pastatyti naujajį vamzdyną. Newsru, ,„Дружба ” врозь-правительство одобрило план строительства обходного нефтепровода, 2007 m. gegužès 22 d., www.newsru.com/finance/22may2007/druzhba.html, 20070610.

112 ИА Regnum, Вайншток: Стоимость проекта БТС-2 - около 2,5 млрд долларов, 2007 m. birželio 10 d., www.regnum.ru/news/841614.html, 20070610.

${ }^{113}$ Odesa $674 \mathrm{~km}$ ilgio, 14,5 mln. tonų naftos per metus pajègumo naftotiekis Odesa-Brodai buvo pradètas tiesti 1996 m. ir baigtas 2001 metais. Juo turèjo būti tiekiama Kaspijos jūros baseino nafta i „Južnyj“ terminalų kompleksą, iš kurio tekètų i Brodus, kur susijungtų su „Družba“ naftotiekiu. Iš Brodų dalis naftos turẻjo atitekti Vakarų Ukrainos naftos perdirbimo gamykloms (apie $4 \mathrm{mln}$. tonų per metus), likusi nafta turejjo išnaudoti „Družba“" naftotiekio rezervą ir pasiekti Slovakija, Vengriją, Čekiją ir Kroatiją. Taip Ukraina ketino sumažinti priklausomybę nuo naftos tiekimo iš Rusijos ir tapti Kaspijos jūros baseino naftos tranzito valstybe. Tačiau dèl ribotų Kaspijos jūros pakrantės valstybių eksporto pajėgumų (pervertintų Azerbaidžano naftos gavybos prognozių) vamzdynas buvo praktiškai nenaudojamas iki 2004 m., kai naftotiekio operatorius „Ukrtransnafta“ nusprendė eksploatuoti naftotiekį reversu (pajëgumas - $9 \mathrm{mln}$. tonų per metus), bet ne importuoti naftą iš Kaspijos jūros, o eksportuoti Rusijos naftą. Plačiau apie projektą žr. Нефтегазовые проектыл. Одесса-Броды,, www.oilcapital.ru/info/projects/63395/private/71862.shtml, 20070829.
} 
iš Kaspijos jūros baseino į Vakarų Europą jungtimi. Tačiau nuolatine projekto problema išliko ir išlieka tiekimas, nes nei Azerbaidžanas, nei Kazachstanas nèra pajėgūs pasiūlyti naftos naujajam vamzdynui: pirma, Azerbaidžanas vis dar visu pajejgumu neužpildo naftotiekio Baku-Tbilisis-Džeichanas (iš Azerbaidžano ị Turkijos uostą), antra, Kazachstano eksporto ị Vakarus pajėgumai taip pat yra riboti dèl siekių diversifikuoti eksporto kryptis ir didinti tiekimą į Kiniją, trečia, Kazachstanas nenori konfliktuoti su Maskva dèl Ukrainos ir Lenkijos, nes Kazachstano eksportas didžia dalimi priklauso nuo tranzito per Rusiją sąlygų. Net jei naftotiekio projektas bus igyvendintas, Lietuvos energetiniam saugumui jis tiesioginiu pasekmių neturès. Netiesioginè pasekmè - Lietuva bus izoliuota nuo besiplètojančios alternatyvios Rusijai naftotiekiu infrastruktūros. Kita vertus, turètu pagerèti „PKN Orlen“ galimybès apsirūpinti nafta iš įvairesniu šaltinių, o tai turètų sustiprinti kompanijos išlikimo galimybes.

\section{Išvados}

Lietuvos ir Lenkijos energetikos sektoriuose gamtinių duju ùkis turi skirtingą reikšmę. Lietuvos geoenergetinei paděčiai jis yra svarbesnis, nes, pirma, gamtinès dujos sudaro santykinai didesnę dali pirminių energijos šaltinių vartojime. Antra, Lietuva yra visiškai priklausoma nuo gamtinių dujų tiekèjos Rusijos. Pagrindinis skirtumas tarp Lietuvos ir Lenkijos yra toks, kad Lenkija yra gamtinių dujų tranzito iš Rusijos ị Vakarų Europą (Vokietiją) valstybè, o tai jai suteikia geoenergetinį pranašumą prieš Lietuvą, kuri gali būti priskirta vartotojams. Lenkija turi daugiau svertų derantis su Rusija dèl gamtinių dujų kainų ir sąlygu, taip pat ir garantiju, kad nenutrūks gamtinių dujų tiekimas. Lietuva ir Lenkija nẻra tarpusavyje tiesiogiai susijusios gamtinių dujų sektoriuje - jų nesieja bendra energetinè infrastruktūra. Dvi valstybes šiuo metu vienija tik priklausomybė nuo Rusijos gamtinių dujų importo. Tačiau Lietuvos iš Rusijos perkamas gamtinių dujų kiekis yra per daug mažas, kad dèl jų tarp vartotojų vyktų konkurencija. Todèl šiuos santykius galima laikyti geoenergetiškai nereikšmingais.

Lietuvos santykiai su Rusija (dominuojantis tiekejjas) gamtiniu duju srityje galètų būti priskiriami kontrolès perėmimui - „Gazprom“ visiškai kontroliuoja gamtinių dujų tiekimą Lietuvai, turi trečdali „,Lietuvos dujos“ akcijų, o per jas gali riboti alternatyviu dujotiekiu projektu igyvendinimą. Lenkijos (transportuotojos) santykiai su Rusija (tiekèja) gali būti priskirti bendradarbiavimui tarp lygiaverčiu partnerių. Rusija yra priklausoma nuo Lenkijos gamtiniu dujų tranzito infrastruktūros ir bando kartu su vartotojais (Vakaru Europos valstybėmis) šią priklausomybę sumažinti - plečia alternatyvią Lenkijai tranzito infrastruktūrą. Lenkija siekia atvirkščiai - didinti tranzitinị pajejgumą ir blokuoti vartotojų bei tiekëju (jų interesai transportuotojų atžvilgiu sutampa) bandymą apeiti tranzito valstybę.

Lietuva ir Lenkija neturi galimybių sujungti savo dujotiekių tinklų. Per abi šias šalis nesidrieks tranzitiniai maršrutai, todel Lietuvos ketinimai tapti 
gamtinių dujų tranzito iš Rusijos į Vakarų Europą šalimi yra nepagrịsti. Tokios linijos po keliasdešimt metų gali kirsti tik Lenkijos teritoriją. Lietuvos galimybės jungtis prie Lenkijos igyvendinamų gamtinių dujų tiekëjų diversifikavimo projektų taip pat yra pervertintos. Jei nebus plečiami gamtinių dujų tranzito per Lenkiją pajègumai, šalis iš lygiavertès transportuotojos taps vartotoja santykiuose su dominuojančiu tiekèju - atsidurs tokioje pačioje padètyje kaip Lietuva. Santykiai tarp vartotoju tiekimo diversifikavimo srityje remiasi konkurencija dèl tiekëjų ir tiekimo kelių. Todèl Lenkija sutiktų sujungti dujotiekių tinklą su Lietuva tik tuo atveju, jei Lenkijai tai užtikrintų transportuotojos padèties susigrąžinimą. Tačiau Lietuvos vartojimo kiekis niekada nebus toks, kad sudarytu reikšmingesnę dalį Lenkijos vartojimo ir paveiktų jos energetinį saugumą.

Dėl šių priežasčiuc Lietuvai reikia pačiai, nepriklausomai nuo Lenkijos, pirma, diversifikuoti tiekimo kelius ir tiekejus, antra, plèsti tranzito funkciją. Alternatyviais vamzdynais gamtinès dujos Lietuvos nepasieks, lygiai taip, kaip nepasieks ir turimais vamzdynais alternatyvių tiekëjų dujos. Todèl vienintelè diversifikacijos galimybè yra SGD terminalo statyba Lietuvoje. Tranzito plètros srityje Lietuva turètų sudaryti palankias gamtinių dujų tiekimui į Kaliningrado sriti sąlygas ir siekti tiekëjo sprendimo aprūpinti eksklavą neapeinant Lietuvos. Nẻ viena šių energetinio saugumo užtikrinimo krypčių nẻra paremta geoenergetiškai prasmingų santykių su Lenkija būtinybe.

Lietuvos ir Lenkijos padètis elektros energijos ūkyje taip pat skiriasi. Lietuva yra elektros energijos tiekëja tik iki 2010 m., Lenkija ilguoju laikotarpiu ja išliks. Taip pat, kaip ir gamtinių dujų ūkio atveju, Lietuvos ir Lenkijos nesieja geoenergetiškai prasmingi santykiai. Nors abi valstybės yra elektros energijos tiekejjos (eksportuotojos), tačiau ju nesieja jokie elektros tinklai, tiekimas taip pat yra vykdomas skirtingiems vartotojams (Lenkija priklauso UCTE, Lietuva UPS/IPS sistemai). Todèl galima teigti, kad Lietuvos ir Lenkijos santykiai elektros energijos srityje neturi įtakos šalių energetiniam saugumui.

Santykiai tarp šalių atsirastų, jei jas tiesiogiai sujungtų elektros linijos arba jos pradètų tiekti energiją tiems patiems vartotojams. Elektros tilto tarp Lenkijos ir Lietuvos projekto igyvendinimas būtų geoenergetiškai susaistęs dviejų valstybių energetikos sektorių elektros energijos ūkius. Tačiau visiškai natūralu, kad tai neįvyko, nes Lietuvos ir Lenkijos santykiai būtų kaip lygiaverčių tiekẻjų - konkurencija dèl vartotojų ir priẻjimo prie perdavimo tinklų. Kiekvieno tiekëjo interesas yra išvengti tokios konkurencijos, todèl galima suprasti ir Lenkijos sprendimą vilkinti jungties statybą.

Nutraukus Ignalinos AE veiklą, Lietuva taps elektros energijos vartotoja santykiuose su dominuojančiu elektros energijos tiekejju. Tačiau net ir tada Lenkijos energetiniam saugumui nebūtų naudinga sujungti abiejų šalių tinklus, nes Lietuva turètu galimybę stiprinti tranzito veiklą ir tapti Rusijos elektros energijos transportuotoja i Lenkiją. Šis scenarijus turètų sustiprinti Lietuvos energetini saugumą, nes numatytų bendradarbiavimą su tiekẻju ir vartotoju. Lenkijai tai nebūtų naudinga, nes susilpnètų jos, kaip esamos tiekëjos, pozicijos. Lenkija taip pat taptų priklausoma nuo Lietuvos. Energetinio saugumo požiūriu vienintelè priimtina alternatyva Lenkijai, jei nebūtų kitos išeities ir tektų 
tinklus sujungti, būtų pačiai plèsti elektros energijos tranzitą ir tapti elektros energijos transportuotoja. Tačiau tada Lenkija būtų priversta konkuruoti su kitomis Vidurio Europos UCTE valstybėmis dèl elektros energijos tranzito apimčių. Šiam scenarijui ir ruošiasi Lietuvos kaimynè, įtraukdama vidaus perdavimo tinklų ir jungčių su Vokietija plètrą i Lietuvos ir Lenkijos elektros tinklų sujungimo projektą.

Lietuvos energetinio saugumo stiprinimo kryptys tapus elektros energijos vartotoja, yra, pirma, diversifikuoti tiekëjus ir tiekimo maršrutą (padaryti tiekèją priklausomą nuo Lietuvos, ypač jei tiekèjas yra Rusija - neįmanoma dèl mažo elektros energijos vidaus vartojimo), antra kryptis - stiprinti tranzito veiklą ir/arba, trečia, stiprinti tiekimo funkciją. Tiekimo stiprinimas galimas geoenergetiniam subjektui siekiant arba didinti savarankiškumą (mažinti priklausomybę nuo tiekèjo ar tiekëju), arba tapti tiekëju. Naujos atominės elektrinès Lietuvoje statyba leistų Lietuvai vèl tapti elektros energijos eksporto šalimi. Lenkijos dalyvavimas projekte su išankstiniu produkcijos kiekio reikalavimu yra pagrįstas, nes tai, pirma, neutralizuotu Lietuvos galimybes tapti elektros tiekèju Lenkijai ir Lenkijos konkurente. Antra, savos energijos transportavimas elektros tiltu į Lenkiją užtikrintų jo kontrolę ir apribotų Lietuvos galimybę plèsti tranzito veiklą be Lenkijos sutikimo. Dèl šiu priežasčių Lietuvai elektros energijos ūkyje reikia stiprinti tranzitą iš Rusijos ar kitų elektros tiekejju i vartotojas (pavyzdžiui, Skandinavijos šalis), kurios būtų suinteresuotos tiekèju ir tiekimo kelių diversifikacija. Jei norima stiprinti elektros energijos tiekimo veiklą, Lietuvai reikètų vengti tų subjektų įsitraukimo, su kuriais negali klostytis Lietuvai naudingi santykiai (geoenergetine prasme).

Naftos ūkyje Lenkija yra naftos tranzito valstybè. Lietuva naftos tranzito valstybe buvo iki $2006 \mathrm{~m}$. vidurio. Nors šalys nebuvo ir nèra tiesiogiai susietos žaliavinès naftos tiekimo ir/ar tranzito infrastruktūra, jos buvo lygiavertės konkurentės, nes transportavo tos pačios tiekèjos - Rusijos - išteklius. Rusijos siekis riboti tranzito valstybių įtaką, diversifikuoti rinką, didinti vidaus naftos perdirbimą ir plèsti tranzito valstybes aplenkiančią infrastruktūrą (statyti naftotiekį Uneča-Primorskas) atitinka tiekejjo elgseną. Prognozès rodo, kad vidutiniu-ilguoju laikotarpiu Lenkija, kaip ir Lietuva, nebeatliks naftos tranzito funkcijos, taps naftos vartotoja, o tai labai padidins jos energetini pažeidžiamumą.

Nutrūkus naftos tranzitui, Lietuva liko naftos perdirbimo valstybe, tačiau nesavarankiška. Lenkija, kai praras naftos tranzito funkciją, tokios galimybès (likti perdirbejja) neturès, nes jos paklausa naftos produktams viršija perdirbimo pajègumus. Dèl šios priežasties Lenkijos energetinio saugumo poreikiai lemia siekį išnaudoti šiuo metu vis dar turimas transportuotojos pozicijas ir, pirma, diversifikuoti tiekëjus bei tiekimo maršrutus, taip sustiprinant tranzito veiklą, antra, didinti savarankiškumą ir užkirsti kelią šiuo metu lygiavertei tiekejjai (Rusijai) ateityje tapti dominuojančia, nes tai paskatintų naftos ūkio kontrolès praradimą. Lenkijos įmonès ir vyriausybè siekia igyvendinti Odesa-BrodaiPlockas naftotiekio projektą ir tapti Kaspijos jūros tranzito į Vakarų Europą valstybe, nes tai padètų išlaikyti tranzito funkciją ir diversifikuoti tiekejjus bei 
tiekimo maršrutus. Lietuvos šis naftotiekis nepasieks, todèl Lietuva neturi jokių geoenergetinių interesų dalyvauti projekte. Antroji Lenkijos energetinio saugumo naftos sektoriuje kryptis - mažinti tiekejjo potencialą tapti dominuojančiu subjektu. Rusija taptų dominuojančia tiekejja ir susikurtų sąlygas perimti kitų subjektų naftos ūkių kontrolę, kai nuo jos naftos priklausomos valstybès prarastų savarankiško perdirbimo ir tranzito veiklą (įtakos Rusijai svertą). Rusija nutraukè naftos tranzitą per Lietuvą ir taip tikejjosi sukurti sąlygas naftos perdirbimo veiklos kontrolès perèmimui (darant prielaidą, kad MN valdžiusi "Yukos" tuo metu jau negalèjo būti priskiriama tiekejjui). Naftos perdirbimo kontrolè Lietuvoje leistų daryti didelę įtaką Lenkijos naftos sektoriui, priklausomam ir priklausysiančiam nuo naftos produktų importo. Todèl Lenkijos sprendimas įsitvirtinti Lietuvoje („PKN Orlen“ investicijos) sumažino grèsmiu jos energetiniam saugumui intensyvumą.

Lietuvos energetinis saugumas naftos ūkyje ir visame energetikos sektoriuje, praradus naftos tranzito veiklą ir naftos perdirbimo kontrolę, priklauso nuo, pirma, viso naftos ūkio monopolizavimo prevencijos, antra, nuo perdirbimą kontroliuojančių subjektų pasikeitimų. Naftos produktų rinkos ir perdirbimo (plačiąja prasme) monopolizavimo riziką sumažinti galètų savarankiško ir diversifikuoto naftos produktų importo pajėgumai - žaliavos naftos ir naftos produktų terminalo "Klaipėdos nafta“ kontrolè. Pajègumus monopolizuoti šią sritį turi tik „PKN Orlen“, todèl Lietuvos vyriausybè turètu neleisti Lenkijos kompanijai įsigyti šio objekto. Perdirbimą kontroliuojančiu subjektų pasikeitimas padarytų žalą Lietuvai, jei kontrolę perimtų tiekëjas. Lietuvai grèsmę keltų MN ir naftos produktų rinkos kontrolès atitekimas Rusijos kompanijoms, nuo kurių veiklos jau ir dabar yra priklausomas Lietuvos energetikos sektoriaus funkcionavimas.

Geoenergetikoje strateginè partneryste galima tik tarp tų geoenergetinių subjektu, kuriuos sieja bendradarbiavimo santykiai. Bendradarbiavimo prielaidos yra geoenergetiškai reikšmingi ryšiai, subjektų lygiavertiškumas ir viena kitą papildančios geoenergetinės funkcijos visame energetikos sektoriuje arba atskiruose jo ūkiuose. Lietuvą ir Lenkiją šiuo metu geoenergetiškai reikšmingi santykiai sieja tik naftos sektoriuje, tačiau jie nèra paremti bendradarbiavimu. Elektros energetikos ir gamtinių duju ūkiuose Lietuvos ir Lenkijos iš viso nesaisto geoenergetiškai reikšmingi ryšiai. Kaip parodẻ tyrimas, tokiu ryšiu plètimas yra neigyvendinamas arba jų igyvendinimo pasekmė nebūtų bendradarbiavimas. Todèl Lietuvoje nereikètų pervertinti santykių su Lenkija energetikos sektoriuje ir nepelnytai nuvertinti bendradarbiavimą su Baltijos valstybėmis, kurias su Lietuva sieja geoenergetiškai reikšmingi ir perspektyvūs ryšiai. 


\section{Literatūra}

İstatymai, teisès aktai, dokumentai

1. Commission of the European Communities, Communication from The Commission to The Council and The European Parliament. Priority Interconnection Plan, $\operatorname{COM}(2006) 846$ final, $2007 \mathrm{~m}$. sausio $10 \mathrm{~d}$. http:/ / dete.parliament.bg/pub/ ECD/COM_2006_846_EN_ACTE_f.pdf, 20070802.

2. Commission of the European Communities, Commission Staff Working Document. EU Energy Policy Data, SEC(2007)12, 10 October, 2007, http:/ / ec.europa. eu/energy/energy_policy/doc/02_eu_energy_policy_data_en.pdf, 20070810.

3. European Commission, Directorate-General for Transport and Energy, TransEuropean Energy Networks. 1st TEN-E Information Day, 2007 March 30, http:/ / ec.europa.eu/ten/energy/documentation/doc/2007_03_30_ten_e_infoday_ presentation_en.pdf, 20070815.

4. Lietuvos Respublikos Seimas, Lietuvos Respublikos atominès elektrinès ịstatymas, X-1231, 2007 m. birželio 28 d., http:/ / www3.lrs.lt/pls/inter3/dokpaieska. showdoc_l?p_id=301267, 20070710.

5. Lietuvos Respublikos Seimas, Nutarimas del Nacionalinés energetikos strategijos patvirtinimo, Nr. X-1046, 2007 m. sausio 18 d., http:/ / www3.lrs.lt/pls/inter3 / dokpaieska.showdoc_1?p_id=291371, 20070901.

6. Lietuvos Respublikos Vyriausybe், Nutarimas dél Lietuvos Respublikos Vyriausybès 2006 metu veiklos ataskaitos pateikimo Lietuvos Respublikos Seimui, Nr. 307, 2007 m. kovo 21 d., http:/ /www.lrv.lt/14_vyr_dok/2006_veikl_atask.pdf, 20070904.

7. The European Parliament and The Council Of The European Union, Decision of The European Parliament and of The Council. Laying Down Guidelines for Trans-European Energy Networks and Repealing Decision 96/391/EC and Decision No 1229/2003/ EC, No 1364/2006/EC, 2006 m. rugsëjo 6 d., http:/ / eur-lex.europa.eu/LexUriServ/site/en/oj/2006/1_262/1_26220060922en00010023.pdf, 20070115.

8. Правительство Российской Федерации, Энергетическая стратегия России на период до 2020 года, No. 1234-p, 200308 28, http://www.minprom.gov.ru/docs/strateg/1/print, 20061125.

\section{İmonių dokumentai}

1. AB "Klaipedos nafta", Metinis pranešimas 2006 m., 2007 m. kovas, http:/ / www. oil.lt/uploads/media/Metinis_pranesimas_2006_patvirtintas.pdf, 20070705.

2. AB „Lietuvos dujos“, 2006 m. konsoliduotas metinis pranešimas, http://www. vpk.lt/uploads/metinis_pranesimas_2006.pdf, 20070801.

3. AB "Mažeikiu nafta“ 2006 metu prospektas-ataskaita, www.nafta.lt/get_file. php?id=117, 20070705.

4. Gassco and DNV, Information Concerning the Planning of the Skanled Gas Pipeline, June 2007, http:/ / www.energinet.dk/NR/rdonlyres/E7D26121FE5C-46C9-9DCB-7BE95E65CD38/0/TheSkanledgaspipelineprojectsummaryver_02_250607.pdf, 20070905. 
5. OAO Gazprom, Annual Report 2006, http://www.gazprom.com/documents/ Report_Eng.pdf, 20070715.

6. Морской газопровод через Балтийское море (проект), http://www.mnr.gov. $\mathrm{ru} /$ part/?act=more\&id=1291\&pid=781, 20070715 .

7. Nabucco Gas Pipeline International GmbH, Nabucco Gas Pipeline Project. Gas Bridge Between Caspian Region/Middle East/ Egypt and Europe, February 2007, http://www.nabucco-pipeline.com/cms/upload/Partner_Logos/Nabucco_presentation_web_Feb_2007.pdf, 20070705.

8. Nabucco Project Description, http://www.nabucco-pipeline.com/project/project-description-pipeline-route/index.html, 20070705.

9. Nabucco Project. Mission Statement/Strategic Goals, http://www.nabucco-pipeline.com/company/mission-statement-strategic-goals/index.html, 20070705.

10. Nord Stream, Project Information Document: Offshore Pipeline Through the Baltic Sea, November 2006, http://www.nord-stream.com/uploads/media/PID_ ENGLISH_01.pdf, 20070722.

\section{Oficialūs pareiškimai, kalbos, interviu}

1. Lietuvos Respublikos užsienio reikalų ministerija, Lietuvos ir Lenkijos strategine partneryste igauna vis daugiau praktiniu pavyzdžiu, 2006 m. birželio 13 d., http:/ / www.urm.lt/index.php?1080257421, 20070806.

2. Metinis Prezidento V. Adamkaus pranešimas (2007 m.), http:/ /www.president. lt/file/metinis2007.pdf, 20070826.

\section{Monografijos ir studijos}

1. Baltic Maritime Outlook 2006. Goods Flows and Maritime Infrastructure in the Baltic Sea Region, March 2006, http:/ /ec.europa.eu/transport/intermodality/ motorways_sea/doc/potential/2006_03_baltic_maritime_outlook.pdf, 2007 0205 .

2. Deksnys R. (darbo vadovas), Atominés elektrinés konkurencingumo Baltijos, Skandinavijos, Vakaru Europos šaliu ir Rusijos elektros energijos rinkose analizé (galutiné ataskaita), Kauno technologijos universiteto Elektros ir valdymo inžinerijos fakulteto Elektros sistemu katedra, $2005 \mathrm{~m}$. gruodžio $1 \mathrm{~d}$.

3. European Commission, Directorate-General for Energy and Transport, European Energy and Transport Trends to 2030, $2003 \mathrm{~m}$. sausio $30 \mathrm{~d}$., http:/ / ec.europa. eu/dgs/energy_transport/figures/trends_2030/1_pref_en.pdf, 20070412.

4. European Commission, Directorate-General for Research, Energy Corridors. European Union and Neighbouring Countries, 2007, http:/ /www.ecn.nl/docs/library/report/2007/b07016.pdf, 20070820.

5. Joint UNDP/World Bank Energy Sector Management Assistance Programme, Russia Pipeline Oil Spill Study, April 2003, http:/ / www.esmap.org/filez / pubs/03403RussiaPipelineOilSpillStudyReport.pdf, 20070205. 
6. Lietuvos Respublikos Ūkio ministerija, Tiekimo saugumas Lietuvos elektros energijos rinkoje. Monitoringo ataskaita, 2007, http: / / www.ena.lt/pdfai/Monitoringas_2007.pdf, 20070906.

7. Panorama of the European Union. Gas and Electricity Market Statistics. 2006 Edition, Luxembourg: Office for Official Publications of the European Communities, 2006, http:/ / ep.eurostat.ec.europa.eu/cache/ITY_OFFPUB/KS-7606-289/EN/KS-76-06-289-EN.pdf, 20070822.

8. Scheepers M., Seebregts A., Jong J., Maters H., EU Standards for Energy Security of Supply. Updates on the Crisis Capability Index and the Supply/Demand Index Quantification for EU-27, http://www.ecn.nl/docs/library/report/2007/e07004. pdf, 20070816.

Akademiniai straipsniai mokslinèje periodikoje, kolektyvinèse monografijose, tyrimų centrų interneto svetainèse

1. Bassan M., „Electricity Statistics - Provisional data for 2006“, Eurostat Data in Focus, 4/2007, http:/ / epp.eurostat.ec.europa.eu/cache/ITY_OFFPUB/KSQA-07-004/EN/KS-QA-07-004-EN.PDF, 20070802.

2. Jimenez A., ",Statistical Aspects of the Natural Gas Economy in 2006", Eurostat Data in Focus, 14/2007, http:/ / epp.eurostat.ec.europa.eu/cache/ITY_OFFPUB/KS-QA-07-014/EN/KS-QA-07-014-EN.PDF, 20070810.

3. Kröppl C., "Oil Economy 2006“, Eurostat Data in Focus, 13/2007, http:/ / epp. eurostat.ec.europa.eu/cache/ITY_OFFPUB/KS-QA-07-013/EN/KS-QA-07013-EN.PDF, 20070823.

4. Naujos atominés elektrines statybos Lietuvoje igyvendinamumo studijos rezultatu apibendrinimas, 2006 m. spalio 25 d., http:/ / www.lpc.lt/repository/Summary \%20Report\%20for\%20Media\%20-\%20LT.pdf, 20070813.

5. Statistikos departamentas prie Lietuvos Respublikos Vyriausybès, Energetikos statistika 2006 m., http:/ / www.stat.gov.lt/lt/news/view/?id=1923, 200706 20.

6. The BP Statistical Review of World Energy 2007, http://www.bp.com/liveassets/bp_internet/globalbp/globalbp_uk_english/reports_and_publications / statistical_energy_review_2007/STAGING/local_assets/downloads/spreadsheets/statistical_review_full_report_workbook_2007.xls, 20070612.

7. UCTE, Statistical Yearbook 2005, http://www.ucte.org/_library/statsyearbook/Statistical_Yearbook_2005.pdf, 20070903.

\section{Straipsniai periodikoje, agentūrų pranešimai, radijo laidos, nuomonès}

1. AFP, Russian Oil Supplies to Poland, Germany Caught in Belarus Dispute, 2007 m. sausio 8 d., http:/ / www.breitbart.com/article.php?id=070108124819. kkhgowaq\&show_article=1, 20070205. 
2. Alfa.lt, Lietuva ir Lenkija spartina energetini bendradarbiavima, $2007 \mathrm{~m}$. kovo $3 \mathrm{~d}$. http:/ / alfa.lt/straipsnis/127321, 20070805.

3. BNS, Europos Komisija paskyré koordinatoriu energijos tilto iš Lietuvos i Lenkija projektui, 2007 m. rugsëjo $13 \mathrm{~d}$. http:/ / www.euro.lt/lt/naujienos/apie-lietuvos-naryste-europos-sajungoje/naujienos/1471/?print=1, 20070913.

4. BNS, Lietuvos ir Lenkijos elektros tiltas apsimokés, jei ES dengs 75 proc. investiciju, 2007 m. liepos 31 d., http:/ / www.euro.lt/lt/naujienos/apie-lietuvos-narysteeuropos-sajungoje/naujienos/1219/, 20070802.

5. BRE Bank Securities, PKN Orlen. Expansion to Lithuania, 2006 June 5, http:/ / i.wp.pl/a/dibre/aspolek/pkn_050606_eng.pdf, 20070705.

6. Chalupec I., "Mažeikiu naftos" isigijimas - stiprios regioninés grupés Centrinëje Europoje formavimas, 2006 m. gruodžio 15 d., http:/ / www2.orlen.pl/pub/files/MN_Closing_IR_v15122006_LT.pdf, 20070705.

7. Herron J., „Expansion Likely on Norway-Denmark Gas Pipeline“, Dow Jones Newswires, 2007 m. rugsejo 7 d., http:/ /www.downstreamtoday.com/News / ArticlePrint.aspx?aid=5854, 20070906.

8. Interfax, Polish PKN Orlen plans to merge with Lotos, no Warsaw listing for Czech Unipetrol, 2007 September 4, http:/ / www.interfax.com/5/309376/news.aspx, 20070905.

9. Jeziorski M., „Alternative Access“, The Warsaw Voice, 2006 m. sausio 18 d., http:/ / www.warsawvoice.pl/view/10305, 20070810.

10. Juozaitis R., Ilgas lietuviškos elektros kelias i Vakarus, http://neris.mii.lt/mt/ straipsniai/20055/ilg.doc, 20070909.

11. Komaras J.J., „,Kodèl lenkai bijo rusų Mažeikiuose?“, Lrytas.lt, 2006 m. balandžio 9 d., http:/ / www.lrytas.lt/?id=11445789341142311187\&view=4, 20070825.

12. omaras J. J., „Lenko pozicija: kodèl nèra elektros tilto į Vakarus?“, Lrytas.lt, 2006 m. kovo 14 d., http:/ / www.lrytas.lt/ ?id=11422625581141696756\&view=4, 20070115 .

13. Kubilius A., "Mažeikiu nafta“ ir strateginé partnerysté su Lenkija, $2006 \mathrm{~m}$. gruodžio 18 d., http:/ / www3.lrs.lt/pls/inter/w5_show?p_r=4932\&p_ $\mathrm{d}=62373 \& \mathrm{p} \_\mathrm{k}=1,20070903$.

14. Management Board of PGNiG selects the Location for LNG Terminal on the Polish Coast, http:/ / www.en.pgnig.pl/cp/news/478_2208.htm, 20070810.

15. Naujos atomines elektriness statyba. Projekto chronologija, http://www.lpc.lt/lt/ main/atom/Events_nuclear, 20070901.

16. Newsru, ,Дружба“ врозь - правительство одобрило план строительства обходного нефтепровода, 2007 m. gegužès 22 d., www.newsru.com/finance/ 22may2007/druzhba.html, 20070610.

17. Newsru, „Дружбе” конец: трубопровод в Литву не будет отремонтирован, 2007 m. rugsèjo 7d., http://www.newsru.com/finance/07sep2007/druzhba.html, 20070907.

18. Newsru, Россия может быстро построить трубу в обход Белоруссии и отказаться от поставок нефти в Литву, 2007 m. vasario 13 d., www.newsru. com/finance/13feb2007/vainshtock.html, 20070610. 
19. Pakalkaitė V., „Lenkų bilietas į Ignaliną - ir elektros tiltas“, Verslo žinios, 2007 m. sausio 9 d., http:/ /vz.lt/Default2.aspx?ArticleID=79a120d9-7ac6-4912a499-c129d1ab9edf, 20070215.

20. „PGNiG and Energinet.dk reached agreement on Baltic Pipe“, Scandinavian Oil-Gas Magazine, http://www.scandoil.com/moxie-bm2/news/contracts_ world/pgnig-and-energinetdk-rea.shtml, 20070906.

21. PGNiG to Acquire Stake in Norwegian Shelf Licences, http:/ / www.rigzone.com/ news/article.asp?a_id=41995, 20070906.

22. PGNiG Will Acquire Hydrocarbon Reserves on the Norwegian Shelf, http:/ / reakkt. wordpress.com/2007/03/01/pgnig-will-acquire-hydrocarbon-reserves-onthe-norwegian-shelf/, 20070906.

23. „PKN Orlen ambicijos“, Versus, 2007 m. gegužès 7 d., http:/ / www.lrytas. $\mathrm{lt} /$ ?id=11785581771176340376\&view=4\&p=4, 20070905.

24. „PKN Orlen“ taikinys - „Klaipėdos nafta“, Balsas.lt, 2007 m. kovo 28 d., http://balsas.lt/naujienos/verslas/straipsnis68637, 20070822.

25. „Pokalbyje dèl naujos elektrinès - Lenkijos spaudimas“, Bernardinai.lt, $2007 \mathrm{~m}$. liepos 21 d., http:/ / www.bernardinai.lt/index.php?url=articles/65476, 20070725.

26. Poland Moves in New Directions Regarding Liquid Natural Gas Import, http:/ / www.ilf.de/index.php?id=63\&L=1\&tx_ttnews \%5Btt_news $\% 5 \mathrm{D}=131 \& t x \_t$ tne ws\%5BbackPid\%5D=18\&cHash=b675b13948, 20070810.

27. Polish Oil and Gas Company Joins Skanled Consortium, http:/ /www.en.pgnig. pl/316_2414.htm, 20070906.

28. "Russian Oil Exports Down 1\%, Gas Exports 3\% in 2006 - Ministry“, RIA Novosti, 2007 m. vasario 1 d., http:/ /en.rian.ru/russia/20070201/60026020.html, 20070830.

29. Signing of a Letter of Intent Regarding the Construction of the Maritime Gas Terminal in the Port of Gdansk, http:/ / www.portgdansk.pl/events/a-letter-of-intentregarding-the-construction-of-the-lng-terminal, 20070810.

30. Tèvynès Sajunga, Rusijos sulaikymo strategija. Rusijos ịtakos Lietuvoje mažinimo planas, 2007 m. gegužès 9 d., http:/ / www.visuomenei.lt/modules/document_publisher/documents/2/Rusijos\%20sulaikymo\%20strategijos\%20proje ktas\%2007\%2005\%2010.doc, 20070903.

31. Watson C., "Denmark and Poland Considering Gas Pipeline", Energy Business Review Online. http:/ / www.energy-business-review.com/article_news. asp?guid=464FFA34-5CEC-4DFA-A80C-5D0DC8312455, 20070906.

32. „Wintershall сделала предложение Польше“, РБК daily, 2007 m. gegužès 31 d., http://www.rbcdaily.ru/2007/05/31/tek/278103, 20070801.

33. „World Nuclear Review - Week Ending 21st July 2006“, The Nuclear Communication Network, No.29/06. http:/ / www.analys.se/lankar/Internat/NucNet/internatNucRew29_06.htm, 20070215.

34. Zhdannikov D., „Russia sets flat Q2 oil export schedule“, Reuters, 2007 m. kovo 21 d., http:/ / uk.reuters.com/article/oilRpt/idUKL213035720070321, 20070515.

35. Баланс электроэнергии Калининградской энергосистемы на период до 2020 года, http://impera.ru/region/economics/electricity, 20070604. 
36. ИА Regnum, Вайншток: Стоимость проекта БТС-2 - около 2,5 млрд долларов, 2007 m. birželio 10 d., www.regnum.ru/news/841614.html, 20070610.

37. „Калининградская ТЭЦ-2 полностью обеспечивает потребителей области собственной электроэнергией“, Пресс-релиз Калининградская ТЭЦ-2, 2007 m. rugpjūčio 28 d., http://www.ktec2.net/index.php?type=555\&subcat=146, 20070901.

38. Нефтегазовые проекты. Одесса-Броды,, www.oilcapital.ru/info/projects/63395/ private/71862.shtml, 20070829.

39. Рагузина Г., Калининград стал заложником амбиций энергетического и газового гигантов, http://www.bellona.ru/articles_ru/chubais_tec, 20070623.

40. Успенский А., „Поляки требуют от „Газпрома“ отдать долг.

41. EuRoPol GAZ подсчитала разницу в тарифах“, РБК daily, 2007 m. sausio 17 d., http://pda.daily.rbc.ru/2007/01/17/tek/263467.shtml, 20070511.

\section{Žemèlapiai}

1. 330/110kV perdavimo tinklas, http://www.lietuvosenergija.lt/lt/main/system/network, 20070815.

2. Gas Transmission Europe, Operational Procedures at major cross-border interconnection points, http://www.gie.eu.com/download/gridmap/GTE_OP_150. pdf, 20070716.

3. LNG Map. Information by Entry Point, http://www.gie.eu.com/download/gridmap/GLE_LNG_207.pdf, 20070810.

4. Polish Energy Group, http://www.pse.pl/galeria/pge_01.jpg, 20070815.

5. Priority Projects for Electricity, http://ec.europa.eu/ten/energy/studies/ doc/2004_brochure/electricity_network_07_en.jpg, 20070812. 